\title{
300 Area Disturbance Report
}

\author{
M. K. Wright \\ L. L. Hale \\ N. A. Cadoret
}

December 1998

Prepared for

the U.S. Department of Energy

under Contract DE-AC06-76RLO 1830

Pacific Northwest National Laboratory

Richland, Washington 99352 


\section{DISCLAIMER}

This report was prepared as an account of work sponsored by an agency of the United States Government. Neither the United States Government nor any agency thereof, nor any of their employees, make any warranty, express or implied, or assumes any legal liability or responsibility for the accuracy, completeness, or usefulness of any information, apparatus, product, or process disclosed, or represents that its use would not infringe privately owned rights. Reference herein to any specific commercial product, process, or service by trade name, trademark, manufacturer, or otherwise does not necessarily constitute or imply its endorsement, recommendation, or favoring by the United States Government or any agency thereof. The views and opinions of authors expressed herein do not necessarily state or reflect those of the United States Government or any agency thereof. 


\section{DISCLAIMER}

Portions of this document may be illegible in electronic image products. Images are produced from the best available original document. 


\section{Summary}

The objective of this study was to define areas of previous disturbance in the 300 Area of the U.S. Department of Energy (DOE) Hanford Site to eliminate these areas from the cultural resource review process, reduce cultural resource monitoring costs, and allow cultural resource specialists to focus on areas where subsurface disturbance is minimal or nonexistent. Research into available sources suggests that impacts from excavations have been significant wherever the following construction activities have occurred: building basements and pits, waste ponds, burial grounds, trenches, installation of subsurface pipelines, power poles, water hydrants, and well construction. Beyond the areas just mentioned, substrates in the 300 Area consist of a complex, multidimensional mosaic composed of undisturbed stratigraphy, backfill, and disturbed sediments.

Four Geographic Information System (GIS) maps were created to display known areas of disturbance in the 300 Area. These maps contain information gleaned from a variety of sources, but the primary sources include the Hanford GIS database system, engineer drawings, and historic maps. In addition to these maps, several assumptions can be made about areas of disturbance in the 300 Area as a result of this study:

- Buried pipelines are not always located where they are mapped. As a result, cultural resource monitors or specialists should not depend on maps depicting subsurface pipelines for accurate locations of previous disturbance.

- Temporary roads built in the early 1940 s were placed on layers of sand and gravel 8 to 12 in. thick. Given this information, it is likely that substrates beneath these early roads are only minimally disturbed. Building foundations ranged from concrete slabs no more than 6 to 8 in. thick to deeply excavated pits and basements. Buildings constructed with slab foundations are more numerous than may be expected, and minimally disturbed substrates may be expected in these locations.

- Historic black and white photographs provide a partial record of some excavations, including trenches, building basements, and material lay-down yards. Estimates of excavation depth and width can be made, but these estimates are not accurate enough to pinpoint the exact location where the disturbed/undisturbed interface is located (e.g., camera angles were such that depths and/or widths of excavations could not be accurately determined or estimated). In spite of these limitations, these photographs provide essential information.

- Aerial and historic low-level photographs have captured what appears to be backfill throughout much of the eastern portion of the 300 Area-near the Columbia River shoreline. This layer of fill has likely afforded some protection for the natural landscape buried beneath the fill. This assumption fits nicely with the intermittent and inadvertent discoveries of hearths and stone tools documented through the years in this part of the 300 Area. Conversely, leveling of sand dunes appears to be substantial in the northwestern portion of the 300 Area during the early stages of development. 
- Project files and engineer drawings do not contain information on any impromptu but necessary adjustments made on the ground during project implementation-after the design phase. Further, many projects are planned and mapped but never implemented-this information is also not often placed in project files.

Specific recommendations for a 300 Area cultural resource monitoring strategy are contained in the final section of this document. In general, it is recommended that monitoring continue for all projects located within $400 \mathrm{~m}$ of the Columbia River. The $400-\mathrm{m}$ zone is culturally sensitive and likely retains some of the most intact buried substrates in the 300 Area. 


\section{Contents}

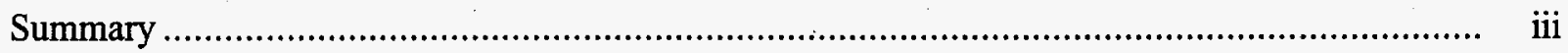

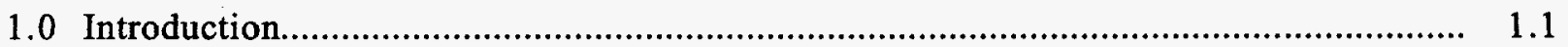

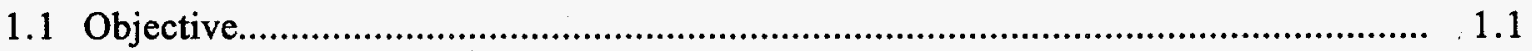

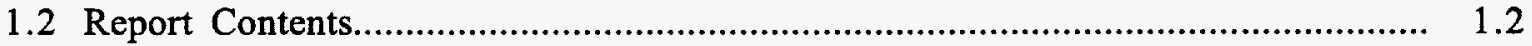

2.0 Background .......................................................................................................... 2.1

2.1 Archaeological Evidence of Past Uses ................................................................... 2.5

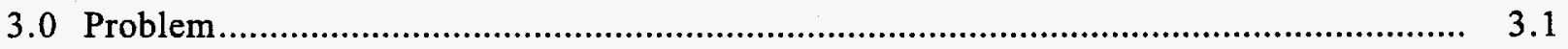

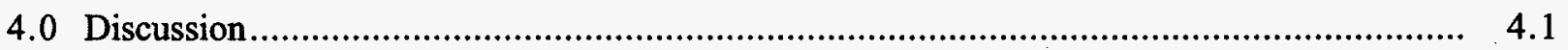

4.1 Remote Sensing Studies.................................................................................... 4.1

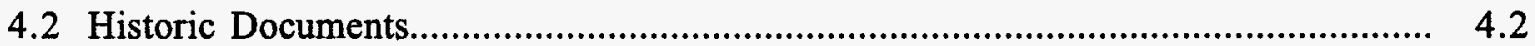

4.2.1 Initial Construction: Paved and Gravel Roads .............................................. 4.2

4.2.2 Construction: Facility and Structure............................................................... 4.2

4.3 Historic Photographs ............................................................................... 4.4

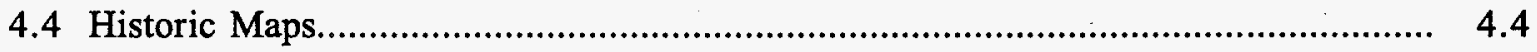

4.5 Engineer Drawings............................................................................................. 4.4

4.6 Water and Monitoring Wells.......................................................................... 4.4

4.7 Hanford Geographic Information System Maps....................................................... 4.5

4.8 Facilities Located Within the 400-m Zone........................................................... 4.5

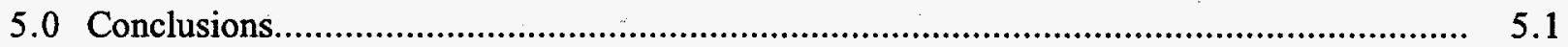

5.1 Areas of Disturbance ........................................................................................ 5.1

5.2 Recommendations for Future Study ……............................................................ 5.6

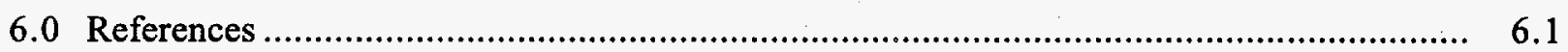

Appendix A - 300 Area: Geophysical Survey Maps.................................................... A.1

Appendix B - 300 Area: Photographs.......................................................................... B. B.

Appendix C - 300 Area: Historic Maps............................................................................ C.

Appendix D - 300 Area: Facilities Evaluation of Disturbance.................................................. D. 1

Appendix E - 300 Area: Well Log Deposit Records ............................................................. E.1 


\section{Figures}

2.1 Black and White Aerial Photograph Taken in 1930 of the Lands that Would Become the 300 Area in 1943.

2.2 Landownership as of 1943 Before Government Acquisition ................................... 2.3

2.31948 Aerial Photograph of the Early 300 Area .............................................. 2.4

2.4 Generalized Stratigraphic Profile of 300-Area Sediments...................................... 2.6

3.1 1987 Color Aerial Photograph of the 300 Area Industrial Development..................... 3.2

4.1 Location Map for Geologic Cross Sections in the 300 Area................................... 4.6

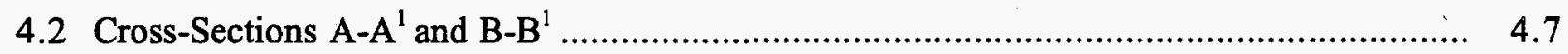

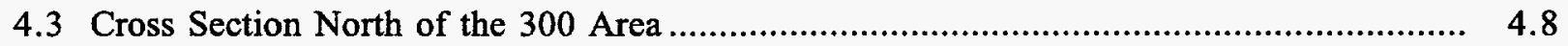

5.1. Buildings and Their Patterns of Disturbance in the 300 Area.................................. 5.2

5.2 The Modern Topography of the General 300 Area as Recorded in the Sitewide GIS Database

5.3 Underground Facilities as Recorded in the Sitewide GIS Database ............................. 5.4

5.4 Areas of Discrete Disturbance Throughout the 300 Area as Recorded in the Sitewide GIS Database

\section{Tables}

4.1 Results of 1991 Geophysical Surveys........................................................... 4.3

4.2 Information About Stratigraphy in Early 1940s Well Logs ................................... 4.9

4.3 Buildings/Facilities Located Within the 400-Meter Zone of the Columbia River Including Demolished Buildings

5.1 Monitoring Recommendations for Excavation Activities in Specific Areas. 


\subsection{Introduction}

Native American people and their ancestors lived in and near the 300 Area from prehistoric times to the recent past (Relander 1986). The physical evidence of the Native American presence and of the EuroAmerican settlers that followed is expressed today as prehistoric and historic archaeological sites. As populations slowly increased, ground disturbing activities-associated with the construction of roads, homesteads and farmsteads, irrigation canals, and towns-began to gradually change the landscape.

By 1930 , several farms, a school, irrigation canals, and a small town were present in the area known today as the 300 Area. Following federal acquisition of the land by the Manhattan Project in the early 1940 s, the 300 Area became the location of the uranium fuel fabrication plants that manufactured fuel for Hanford reactor operation, the first essential step in the plutonium production process. At that time, the Site's research and development laboratories also were located in the 300 Area.

The industrial development of the 300 Area resulted in substantial changes to the landscape. Construction activities and industrial development have continued through the years to the present time. With each passing phase of new construction, the challenges of repairing, maintaining, and excavating new basements, foundation footings, trenches, and pipelines for water, sewage, and waste transport increased. Not only did draftsmen design new buildings and roads, but they were faced with managing construction activities to avoid (whenever possible) the buried residue of previous land-use activities. Often, the location of buried infrastructure, such as pipelines, was poorly known and/or recorded, resulting in the need to excavate footings, trenches, or holes by hand to ensure, for example, that active or "live" pipes or wires were not severed or damaged.

The subsurface of the 300 Area contains a wealth of information about previous land-use practices, including prehistoric and ethnographic use, historic use and development, and the industrial development associated with the Manhattan Project and the Cold War eras. Although industrial development has slowed in the 300 Area, the need to consider the presence or absence of buried cultural deposits (whether prehistoric or historic in nature) is a primary factor in the success of future planning and in meeting requirements of the National Historic Preservation Act, as amended.

\subsection{Objective}

The objective of this study was to define areas of previous disturbance in the 300 Area and display these areas of disturbance on Geographic Information System (GIS) maps. Standard research methods were used throughout the study period. A wide range of Hanford Site documents and records were investigated for this project. The sources researched include but are not limited to electronic databases, engineer drawings, historic documents and records, technical reports, project reports, maps, and photographs. Each source was considered for its ability to provide sound quantitative data for the disturbance project. Four GIS maps depicting verifiable areas of disturbance for the 300 Area were developed. These maps can be used to eliminate areas of disturbance from the cultural resource review process, reduce monitoring costs, and allow cultural resource specialists to focus their investigations in the 400-m zone where buried cultural resources are known to exist and where subsurface disturbance is minimal or nonexistent. 


\subsection{Report Contents}

Section 2.0 of this report briefly describes land use patterns through time. This section also discusses cultural resource sites and historic properties known to exist within and adjacent to the 300 Area. Section 3.0 introduces the issues associated with cultural resource monitoring of previously disturbed ground and preservation of unanticipated cultural deposits. Section 4.0 contains information about areas of previous disturbance. These data have been extracted from a variety of sources and provide the baseline data for the GIS disturbance maps and recommendations for further study. Conclusions and recommendations for further study are presented in Section 5.0. Appendices $A$ through $E$ provide supporting information. 


\subsection{Background}

Native American people have been in the 300 Area and surrounding region for thousands of years, as evidenced by archaeological deposits, oral histories, and historic accounts (Relander 1986; Swindell 1942). EuroAmerican resettlement of the Hanford Site began during the 1800 s as cattlemen passed through the area with livestock. The settlers that followed built homes and irrigation systems. Communities sprang to life at White Bluffs, Hanford, Richland, and Wahluke. EuroAmerican settlement was coupled with concurrent changes in the Native American lifestyle and subsistence as the non-Indian population increased.

During the 1930s, the lands that would become the 300 Area were characterized by stabilized dunes and sparse vegetation (Figure 2.1). Although some settlement had occurred, only minor modifications had been made to the landscape including a north/south trending irrigation ditch, the fledgling community of Fruitland, agricultural fields, widely scattered structures, and several informal roads (Figure 2.1). Settlement continued into the early 1940s. (Figure 2.2), but following federal acquisition of the Hanford Site in 1943, all residents of the Site, including those located near the future 300 Area, were asked to leave. Soon after, the E.I. du Pont de Nemours and Company, Inc., began an assessment of pre-existing conditions and facilities at the future 300 Area (du Pont 1945).

Industrial development in the 300 Area began to take shape April 6, 1943, as site layout work and a preliminary topographic survey began. Originally, the entire 300 Area-from the road to the Columbia River and from the north fence line to the south fence line-comprised approximately 115.25 acres, of which 52.5 acres were fenced (Figure 2.3).

A topographic survey of the proposed 300 Area was completed during the start-up phase of the Manhattan Project. The layout design of temporary and permanent buildings and other facilities such as roads, sewer systems and walkways was completed April 28, 1943. The topographic surface and existing improvements of the 300 Area were ably described in du Pont's Construction Hanford Engineer Works...History of the Project Volume IV (1945):

There was one principal and highly useful facility available in the vicinity of the 300 Area prior to the start of construction. This was the $66 \mathrm{KV}, 20,000 \mathrm{KVA}, 3$ phase, Pacific Power and Light Company's line between Hanford and Pasco, which was used as the source of all power for the Area, both temporary and permanent.

A semi-bituminous two-lane road, which was the main highway between Pasco and Hanford, paralleled the future southern boundary of the Area at a distance of approximately one mile. A narrow, gravel unfaced road extended from the highway to the vicinity of the 300 Area. Vegetation in the Area consisted of the usual desert plants, i.e., sagebrush, greasebushes and cheet grass.

The soil conditions in the 300 Area are in general similar to those encountered in the Richland Area. The land, prior to the start of construction, was fairly level, varying from a high of approximately 400 feet above sea level (in the north and eastern portion of the area) to a low of 388 feet above sea level in the southwestern portion. To the east, outside the fence line, the land gently slopes to the level of the river 


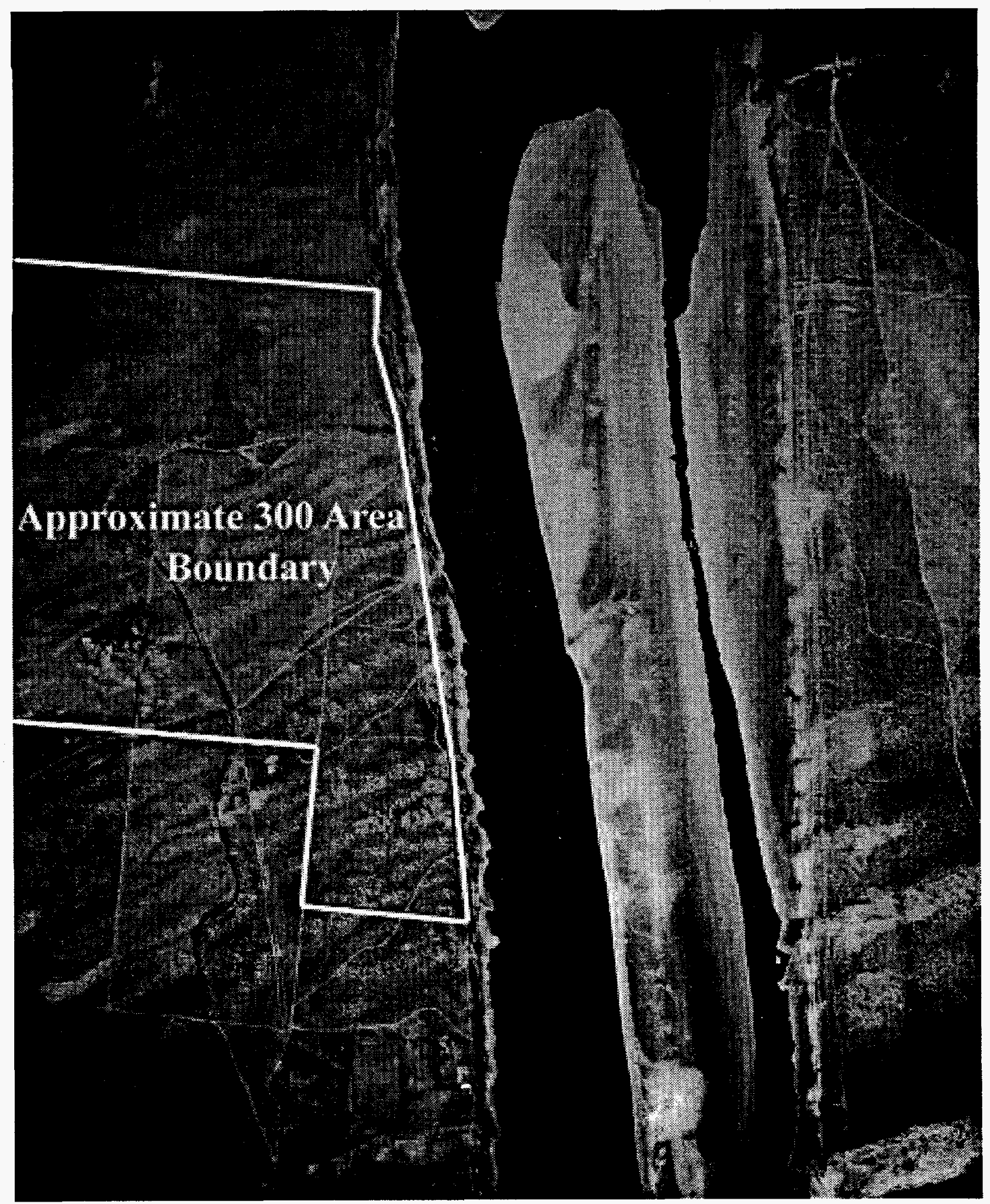

Figure 2.1. Black and White Aerial Photograph Taken in 1930 (USGS 1930, A40, 1:22,500) of the Lands that Would Become the 300 Area in 1943 
Township 10 N, Range 28 E., Sections 2 and 11

\section{Willamette Meridian}

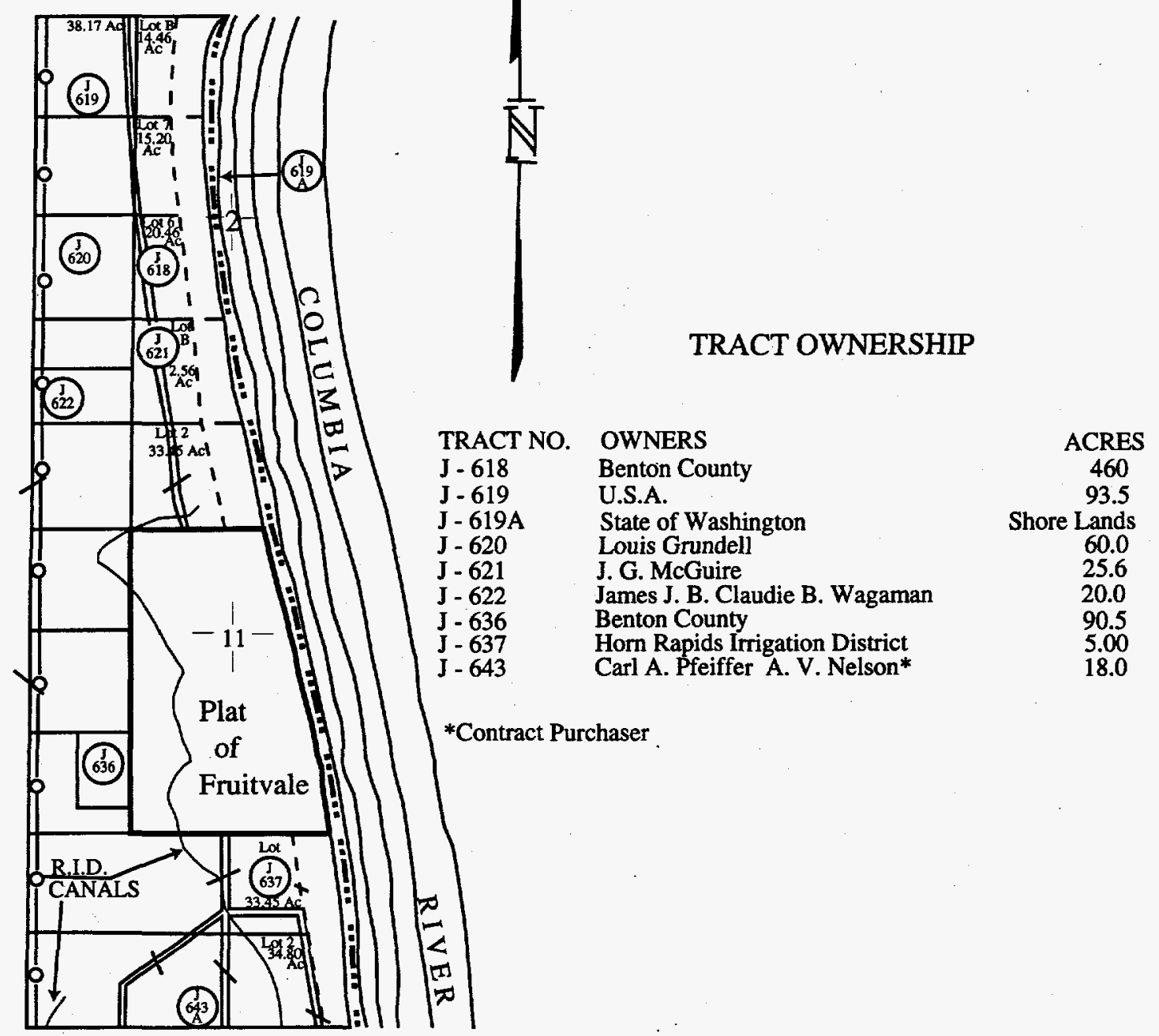

FROM HANFORD ENGINEER WORKS REAL ESTATE MAP, 7/2/43.

Figure 2.2. Landownership as of 1943 Before Government Acquisition (USAEC 1943, Segment "J") 


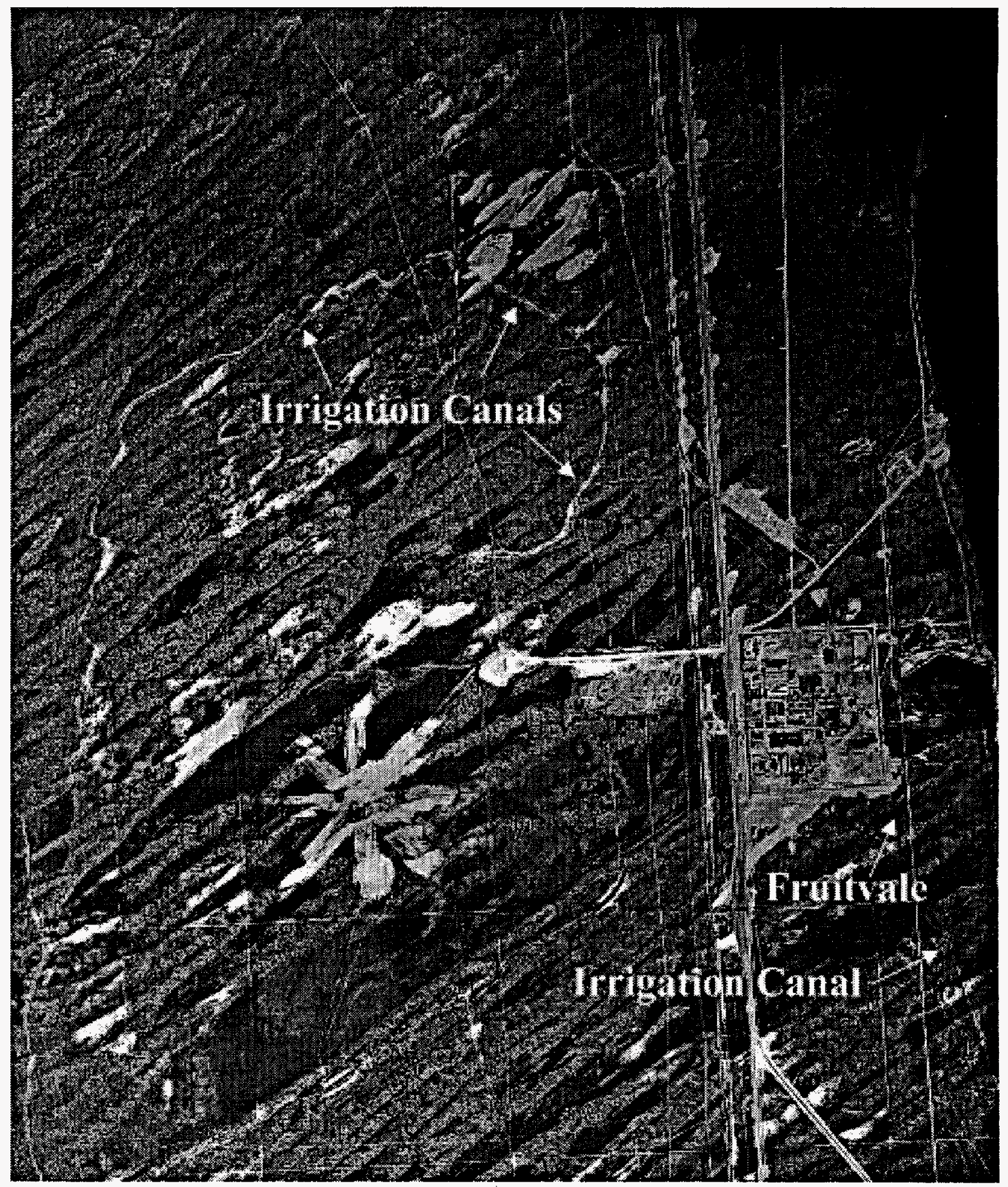

Figure 2.3. 1948 Aerial Photograph (GS-XB 2-21) of the Early 300 Area. (Note the landform morphology in surrounding lands.) 
which varied from a height of $333 \mathrm{ft}$ to $348 \mathrm{ft}$ above sea level during 1944. Essentially the soil materials in the 300 Area are the remains of a large sand and gravel bar developed by the waters of the Columbia River as it carried the melted snows from the Cascade Range. The top soil varies in depth from 4 to 12 inches and consists of a grayish sandy loam or a grayish unstable silt loam. Below the top soil is a low clay content stratum of yellow sand varying in thickness from 8 to 24 inches. This layer at certain locations has a uniform size of the sand grains and approximates the size of sugar particles, while at other locations the material contains enough larger particles of graded gravel to be classified as a gravelly sand and is quite a stable material. Where the layer approaches the size and uniformity of sugar the material has very little stability in supporting wheel loads, and cut slopes must be exceedingly gentle to attain a stable angle of repose. Directly underlaying the sand layer is a stratum of gravel varying in particle size from a maximum of 6 to 8 inches in diameter to minute particles and containing some $25 \%$ of sand smaller than $1 / 4$ inches. This stratum has an average depth of some 50 to 100 feet. Below the gravel stratum lies the parent material of the Columbia River Valley. This material is a grayish to blue shale.

According to this early description, the "top soil" and "stratum of yellow sand," or Holocene layer, was between 2 to $3 \mathrm{ft}$ deep before leveling activities began. It is this layer that likely contains any physical record of human habitation in the 300 Area. More recent geologic studies suggest that the thickness of the Holocene layer in the 300 Area is variable and considerably deeper than the original topographic survey suggested. According to Schalla (1988), Holocene deposits in the 300 Area are evidenced by a "thin veneer of fine-to-coarse-grained, eolian (wind transported) sand deposits" of varying thicknesses ranging from 0 to $15 \mathrm{ft}$ (Schalla:3.21). Figure 2.4 depicts a generalized stratigraphic profile of 300-Area sediments.

Ongoing industrial development in the 300 Area has meant that much of the surface and portions of the subsurface deposits have been impacted by activities associated with road construction; building and facility development; parking lot paving, basin, pond, and trench excavation; underground tank emplacement; and underground utilities. Ground disturbances associated with these activities are infinitely variable in their depth, width, and length.

\subsection{Archaeological Evidence of Past Uses}

Five archaeological sites, including cemeteries, campsites, historic debris scatters, farmstead features and agricultural fields, are located at least partially within the 300 Area; many more are located within $1 \mathrm{~km}^{2}$ of the 300-Area fence line. One prehistoric archaeological site has been found to be eligible for listing in the National Register of Historic Places (National Register).

The 300 Area was also the location of uranium fuel fabrication plants and contains most of the Site's research and development laboratories. Forty-seven buildings/structures have been determined to be eligible for listing in the National Register as contributing properties (USDOE 1996).

- HT-97-005. This is a historic site containing pieces of flat glass, canning jar fragments, ceramic, metal parts, a railroad spike, and rocks cut with a rock saw that were pushed over the bank near the Columbia River. 


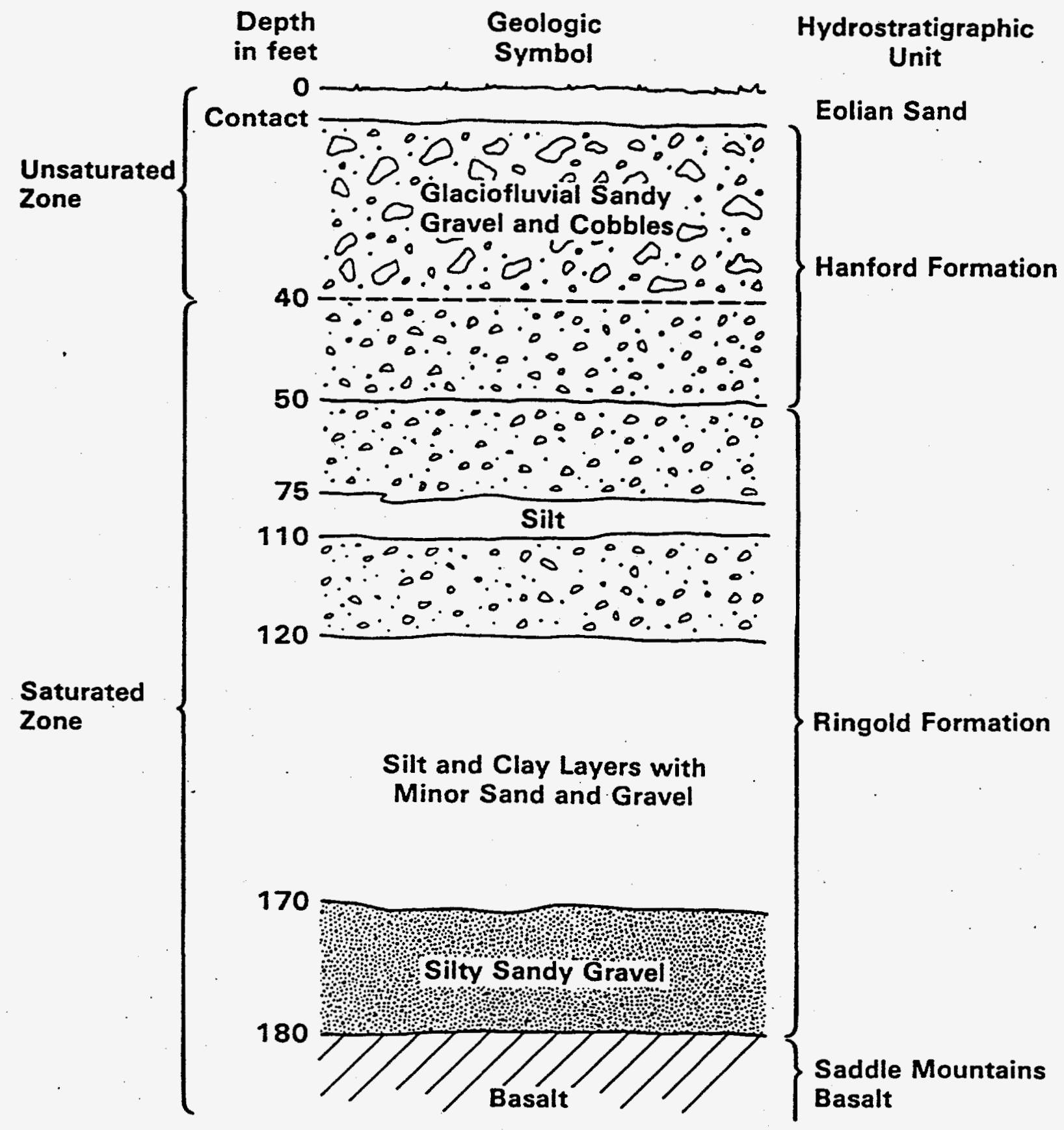

Not to Scale

Figure 2.4. Generalized Stratigraphic Profile of 300-Area Sediments 
- HI-89-001. A cryptocrystalline flake was located in a 'blow-out' area in stabilized dunes.

- HI-91-003. A single milling stone was encountered in backfill along excavated trenches in the 300 Area. A ground, smooth center on one side of the stone was considered to have been modified by grinding.

- 45BN162. This archaeological site was first recorded by Rice and was later submitted to the State Historic Preservation Office (SHPO) as part of the Hanford South Archaeological District (1983).' In 1996, a buried hearth and/or oven feature was inadvertently impacted during trenching excavations (HCRC \#95-300-030) at 45BN162. An organic soil sample from the hearth, processed by Beta Analytic, produced a date of $2540 \pm 70$ BP (Beta-93433) for the buried feature. The presence of buried, intact cultural features at $45 \mathrm{BN} 162$ suggests that the site and its buried components may be eligible for listing in the National Register.

\footnotetext{
${ }^{1}$ The Hanford South Archaeological District nomination package was drafted but not finalized and was not sent to the Keeper of the National Register. However, due to the significance of the archaeological district, the SHPO placed the Hanford South Archaeological District on the Washington State Register on August 26, 1983.
} 


\subsection{Problem}

The National Historic Preservation Act (NHPA) requires that the effect of an undertaking on any district, site, building, structure, or object that is included in or eligible for inclusion in the National Register must be taken into account. Accordingly, the U.S. Department of Energy, Richland Operations Office (DOE-RL) requires that all proposed projects undergo a cultural resource review to ensure that cultural resources are considered before the project is initiated.

In the 300 Area, much of the landscape is covered with asphalt, fill, trenches, or landscaping (Figure 3.1). In this environment, standard techniques of conducting intensive field surveys to identify and record cultural resources fail to provide the data required to make sound judgments regarding the presence or absence of buried cultural deposits.

The potential for project-driven excavations to impact buried cultural deposits in the 300 Area has long been recognized (Chatters 1989). It is generally recognized that industrial development has extensively impacted the 300 Area, but that pockets of undisturbed sediments remain. Consequently, cultural resource specialists have monitored excavation projects located within $400 \mathrm{~m}$ of the Columbia River since 1989.

In 1996, workers hand-digging a trench through previously deposited fill dirt to lay cable between two prefabricated buildings bisected a buried prehistoric hearth or oven feature as they dug through an unexpected pocket of intact stratigraphic deposits in the northeastern corner of the 300 Area. This inadvertent discovery of a near-surface, intact cultural feature in the northeastern corner of the 300 Area heightened concerns among cultural resource specialists, Native Americans, and DOE officials about the unpredictable nature of buried, intact, Holocene and cultural deposits in the 300 Area.

The 1996 incident highlighted the challenges faced by DOE in balancing the need for full-time monitoring of excavation projects with the cost of funding full-time cultural resource monitors on 300 Area excavation projects. The tension between cultural resource protection and costs associated with monitoring created the need to clearly define areas of disturbance within the 300 Area. If areas of disturbance could be spatially defined, they would no longer require cultural resource reviews or monitoring. This process of elimination would effectively reduce costs and enhance long-term cultural resource management and protection in the 300 Area. 


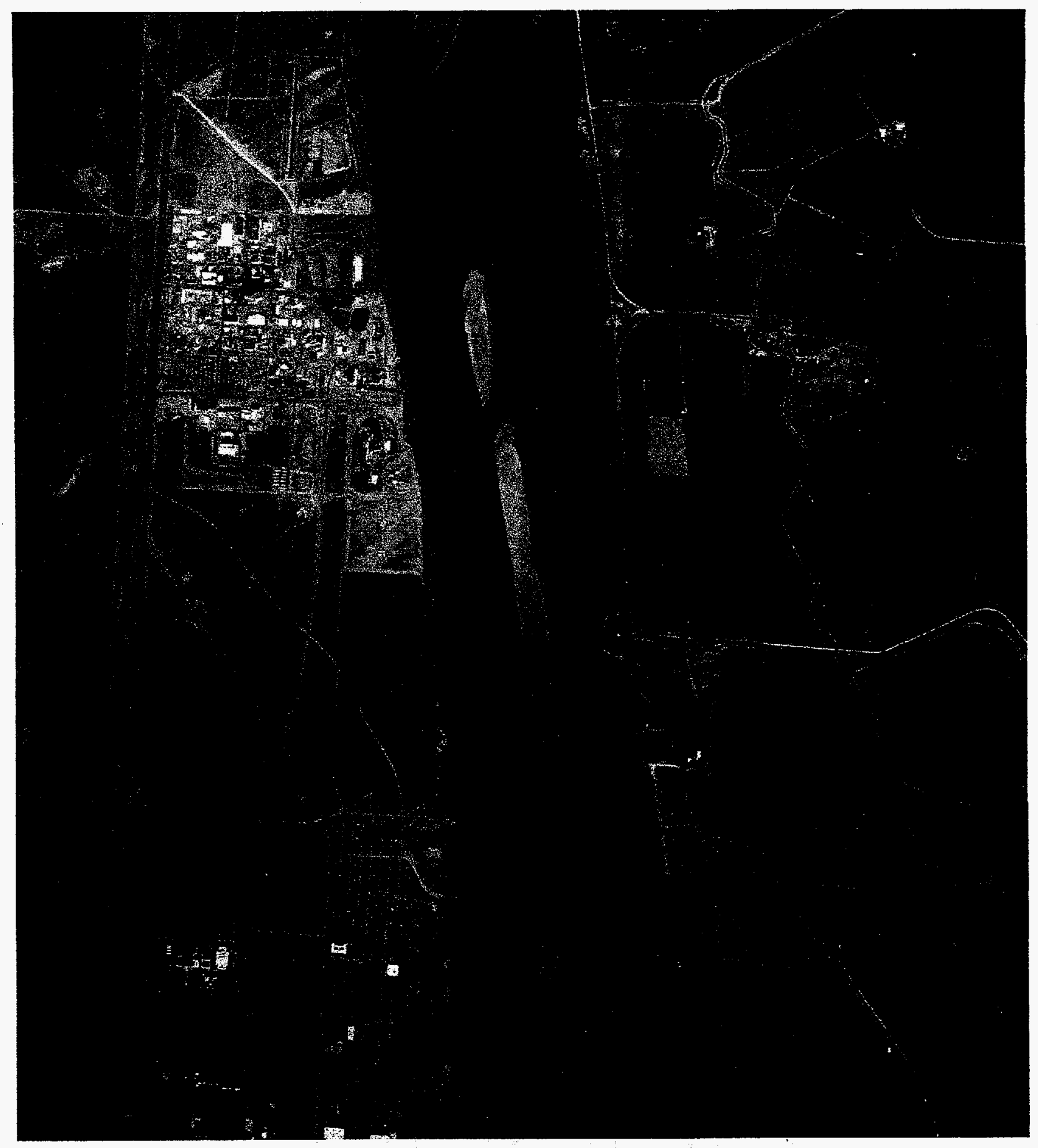

Figure 3.1. 1987 Color Aerial Photograph of the 300 Area Industrial Development (EG \& G 5675 148) 


\subsection{Discussion}

To avoid inadvertent impacts to cultural resources located in or near the 300 Area, DOE-RL requires that all proposed projects undergo a cultural resource review and ensures that excavations located within $400 \mathrm{~m}$ of the Columbia River are monitored. In addition to these standard operating procedures, DOE-RL has suggested that the "mapping" of previously disturbed areas could potentially eliminate such areas from the cultural resource review process, reduce monitoring costs, and allow cultural resource specialists to focus their investigations in areas where subsurface disturbance is minimal or nonexistent.

Fortunately, a variety of information sources exist about previous excavation projects and activities in the 300 Area. Many of these sources, including the following, were readily available and were inspected during the course of this study: geophysical studies, historic records and photographs, engineer drawings, well logs, and historic maps. Other sources of documents also contain information about past excavations in the 300 Area. Historic documents and files containing paperwork on individual 300 Area projects, bills of lading, or project planning are no longer readily accessible because they are archived and are commonly indexed according to project number. These archived documents were not inspected for this study and remain an excellent resource for future research efforts.

Several historic documents contain information about the construction techniques used and excavation dimensions of buildings, roads, pipelines, fence lines, and trenches constructed during the early days of the 300 Area. Engineer drawings provided the quantitative measurements for building basements, pits, footings, foundations, and slab floors necessary for an estimate of disturbances associated with this type of construction. Other excellent sources of information included low-level flight photographs taken from a variety of angles and heights as well as black and white and color aerial photographs that captured several decades of industrial development.

The following sections discuss a variety of different sources. Each source contains information that has been important in the development of GIS maps showing verifiable areas of disturbance in the 300 Area.

\subsection{Remote Sensing Studies}

Pacific Northwest National Laboratory (PNNL) conducted ground penetrating radar (GPR) and electromagnetic induction (EMI) surveys at specific locations in the 300 Area in 1991. These studies were funded to "confirm the locations of abandoned process sewers and radioactive liquid waste sewers as shown on existing maps or to otherwise accurately determine their locations, and second, to attempt to identify locations of possible leaks" (Sandness 1991).

The EMI survey results were expected to be poor-and they were. The low spatial resolution of the EMI and the dense complex of subsurface pipelines and cables produced inadequate EMI readings in this study. The GPR data were, on the other hand, consistently accurate and capable of identifying and mapping underground cable and pipe lines-within specific depth ranges. To map the wide depth 
range of subsurface pipelines, Sandness (1991) suggested surveying each location with frequency bands centered on $100 \mathrm{MHz}, 300 \mathrm{MHz}$, and $500 \mathrm{MHz}$. Unfortunately, the project was limited to the $300-\mathrm{MHz}$ frequency band in the 300 Area. As Sandness stated, using a 500-MHz system would have yielded a high-resolution map of shallow pipeline systems, and using a $100-\mathrm{MHz}$ system would have provided shallow pipeline and cable routes.

The use of GPR and EMI equipment to define subsurface pipeline locations resulted in variable findings (Table 4.1). Often, the mapped location of pipelines corresponded with the GPR readings, but not always. Sandness (1991) found that "the complexity of the subsurface environment in the survey areas . . . and the wide depth range at which the pipelines . . . [were] located, made it difficult to obtain the desired, accurate, pipe-location information with . . . one GPR survey ... ." (1991:26). Further, he recommended that additional GPR surveys using three frequency ranges, $100 \mathrm{MHz}, 300 \mathrm{MHz}$, and $500 \mathrm{MHz}$ were necessary to accurately map underground pipelines (see Appendix A for geophysical survey locations).

Although the remote sensing study provided mixed results with regard to defining subsurface pipelines, it is equally as important to note that the mapped locations of pipelines encountered by Sandness did not always correspond to their actual location as defined by the GPR readings.

\subsection{Historic Documents}

Information gleaned from historic documents provided some information on the physical extent and impact of early construction projects, including roads, buildings, and structures.

\subsubsection{Initial Construction: Paved and Gravel Roads}

"In the 100, 200 and 300 Process Areas, wider temporary roads were constructed to alleviate congested traffic conditions. Many of these roads were laid out on approximately the center-line locations of permanent intra-area and Plant-wide roads, enabling them to be used later as bases for permanent roads. . . Temporary roads were constructed of sand and gravel 8" to 12 " thick, and varied from $16^{\prime}$ to $50^{\prime}$ in width. During the summer months, they were sprinkled to eliminate dust. Pit-run sand and gravel, obtained from areas building excavations or local barrow pits, were used for road building and stabilization purposes (du Pont 1945).

\subsubsection{Construction: Facility and Structure}

The stabilized dunes were leveled in the 300 Area, and supporting facilities such as highways, burrow pits, and waste disposal areas upgraded and created readily visible in black and white aerial photography (Figure 2.3). The layout of 300 Area began April 6, 1943, with the start of the preliminary topographic survey of the area (du Pont 1945:985). Thirty-four permanent buildings, 25 temporary facilities, and approximately 10 temporary offices and craft fabrication shops were constructed in the early years of the Manhattan Project. By 1948, the 300 Area was well established. Expansion continued. By 1987, the original 300 Area was surrounded to the north, east, and south by buildings and facilities, mobile offices and parking lots (Figure 2.4). Initially comprising just 115.5 acres (du Pont 1945:984), the 300 Area has since expanded to 384 acres and approximately 154 buildings and/or structures as of the early 1990s (Cushing 1995). 
Table 4.1. Results of 1991 Geophysical Surveys

\begin{tabular}{|c|c|c|c|}
\hline Survey Area & Features Encountered & $\begin{array}{l}\text { Depth of } \\
\text { Feature(s) }\end{array}$ & Comments \\
\hline$\overline{3 A P S 01}$ & 5 East/West trending pipelines & $5^{\prime}$ and $6^{\prime}$ & Pipelines under Apple Street \\
\hline 3 APS02 & 1 East/West trending pipeline & 8 & $\begin{array}{l}\text { Abandoned clay tile process sewer that } \\
\text { terminates at Pond } 1 \text {. It passes under } \\
\text { railroad track. }\end{array}$ \\
\hline 3APRS1 & $\begin{array}{l}4 \text { pipelines; RLW sewer pipeline, } 3 \\
\text { retention process sewer lines }\end{array}$ & $\begin{array}{l}2,33^{\prime}, 4^{\prime}, 5^{\prime} \\
6^{\prime}, 8^{\prime}, 10^{\prime} \\
\text { and } 11^{\prime}\end{array}$ & North of 324 Building \\
\hline 3APRS3 & $\begin{array}{l}\text { Several pipelines including sections } \\
\text { of the RLW sewer and process sewer }\end{array}$ & $2^{\prime}$ and $6^{\prime}$ & Northwest corner of 324 Building \\
\hline 3APRS2 & $\begin{array}{l}\text { GPR: several underground pipes and } \\
\text { possible electrical cables. Area } \\
\text { congested - sewer lines may be deeper } \\
\text { than the effective detection depth. } \\
\text { EMI: no anomalies that could help } \\
\text { define pipeline locations }\end{array}$ & $\begin{array}{l}\text { Not } \\
\text { Determined }\end{array}$ & $\begin{array}{l}\text { Drawings show abandoned RLW sewers, } \\
\text { a retention process sewer, and an active } \\
\text { process sewer are all located near/under } \\
\text { the east side of } 3718-C \text { Building. }\end{array}$ \\
\hline SAPRS4 & $\begin{array}{l}\text { GPR detected the abandoned RLW } \\
\text { sewer; process sewer; and retention } \\
\text { process sewer; a shallow pipe also } \\
\text { was detected. EMI did not provide } \\
\text { useful indication of underground } \\
\text { pipes. }\end{array}$ & $\begin{array}{l}\sim 8^{\prime}, \sim 14 \text { to } \\
15^{\prime}\end{array}$ & $\begin{array}{l}\text { HEDL Drawing M-3904 provided an } \\
\text { assumed location for the abandoned RLW } \\
\text { sewer at the } 309 \text { Building }\end{array}$ \\
\hline SAPRS5 & $\begin{array}{l}\text { Features assumed to be: segment of } \\
\text { active process sewer } 128 \mathrm{E}, 11^{\prime} \text { deep; } \\
\text { abandoned RLW sewer (131E, } 4^{\prime} \\
\text { deep; abandoned PRTR and RLW } \\
\text { sewer (134E, } 5^{\prime} \text { deep) }\end{array}$ & $\begin{array}{l}11^{\prime}, 4^{\prime}, 5^{\prime}, \\
9^{\prime}\end{array}$ & $\begin{array}{l}\text { Parts of the south and east sides of the } \\
307 \text { Ponds were surveyed. Some } \\
\text { pipelines found by GPR are consistent } \\
\text { with Drawing M-3904, others are not. }\end{array}$ \\
\hline $\begin{array}{l}\text { SARS1 and } \\
\text { 3ARS2 }\end{array}$ & $\begin{array}{l}\text { Pipeline at expected location of RLW } \\
\text { sewer; a second pipeline or cable that } \\
\text { could be the retention process sewer } \\
\text { but is several feet south of the } \\
\text { expected location and is too shallow; } \\
\text { third pipeline or cable to south end of } \\
\text { survey area. }\end{array}$ & $\begin{array}{l}4^{\prime}, 2^{\prime}, 8^{\prime} \text { to } \\
10^{\prime}\end{array}$ & $\begin{array}{l}\text { Survey areas located to the west and east } \\
\text { of the } 3762 \text { Building. }\end{array}$ \\
\hline $\begin{array}{l}618-5 \\
\text { Burial } \\
\text { Ground }\end{array}$ & $\begin{array}{l}\text { Man-made material detected along } \\
\text { three sides of the burial ground. }\end{array}$ & $\begin{array}{l}2 ' \text { or less } \\
\text { but deeper } \\
\text { materials } \\
\text { seemed to } \\
\text { be present. }\end{array}$ & Area inside fence not surveyed \\
\hline
\end{tabular}


Building foundations ranged from simple placement of prefabricated buildings on concrete slabs to the deeply excavated pits for footing and foundation placement. For the most part, the record of this type of disturbance is recorded in drawings and descriptive narratives as buildings and facilities were designed, constructed, and photographed. Information about the structural foundation of buildings in the 300 Area has been consolidated for this report (Appendix A).

\subsection{Historic Photographs}

Construction of the 300-Area complex has been intermittently documented in black and white photographs currently held in the Photography Building. Although Native Americans and EuroAmerican settlers had used lands in what would one day be the 300 Area, none of their settlement activities approached the comprehensive ground disturbance of construction activities undertaken during the Manhattan Project and Cold War eras (Appendix B).

Historic photographs of excavations and construction activities are extremely valuable resources. General scales can be developed to estimate the depth and extent of previous excavations by determining the known dimensions of pictured objects such as buildings or vehicles and applying these measurements to pictured excavations.

\subsection{Historic Maps}

Appendix $\mathrm{C}$ of this document contains images of several historic maps that depict the development and expansion of the 300 Area through time. Although these maps do not show excavation locations, they provide a temporal guideline for the sequence of construction activities, particularly as they relate to facility, structure, and road construction.

\subsection{Engineer Drawings}

The facilities and underground structures in the 300 Area are depicted on engineer drawings and maps intended for use as construction blueprints. These drawings provide essential information about the depth and extent of building foundations, basements, footings, trenches, and pits constructed since initial construction activities began in the 300 Area.

A great deal of information has been gleaned from engineer drawings. Dimensional information about basement and foundation excavations has been consolidated and is presented in Appendix D of this document.

\subsection{Water and Monitoring Wells}

An important source of information about subsurface deposits in the 300 Area is found in well $\log$ records kept during drilling operations. Descriptive records (well logs) of sediments recovered during drilling operations have been kept since 1943 for each well drilled in the 300 Area. Over 60 well logs, most containing detailed notes and measurements, provide important information about subsurface stratigraphy in the 300 Area (Appendix E). Specifics about disturbances associated with well drilling activities are spotty. Two water wells (3905-1/3-6 and 3905-2/3-7) were drilled in 1943 and 1944, respectively. The formation record was captured for these wells (du Pont 1945:986) but 
information about activities preceding drilling e.g., pad preparation, surface excavation, etc., were not described. Wells drilled during the mid-1980s were first excavated to $15 \mathrm{ft}$, then a section of steel casing with drive shoe was placed in the hole, and the hole was backfilled. Well drilling followed site preparation activities (Schalla 1988).

Cross sections of the 300 Area created using the information derived from well logs provide some information regarding the sequence of formations and contact. The Holocene deposits, where the physical evidence of human use is likely to be retained, is displayed as a thin mantle on top of the Hanford formation zones (Figures 4.1, 4.2, and 4.3).

Two water wells were drilled in the 300 Area during the initial layout and construction phases. Basic information was recovered during drilling are shown in Table 4.2 (du Pont 1945).

\subsection{Hanford Geographic Information System (GIS) Maps}

A substantial amount of information about areas of previous disturbance has been compiled in Hanford's GIS mapping database. Information about building basement construction has been folded into this database as a result of this study. Information about areas of previous disturbance include locations for underground utilities, excavations conducted for utility poles, fire hydrants, and wells.

\subsection{Facilities Located Within the 400-m Zone}

Eighty-seven numbered facilities, or portions of facilities, are located within the $400-\mathrm{m}$ zone of the 300 Area (Table 4.3). This zone was established by DOE-RL in recognition of the significance and density of cultural resources along the Columbia River. Most of the buildings and structures, with the exception of waste ponds and basins, were constructed after the initial Manhattan Project period. Many of these facilities have substantial basements and/or pits. Basement and pit excavations were often extensive and resulted in severe alteration of the original landscape. Large quantities of backfill were often distributed nearby. Buildings with large and/or deep basements that are located in the 400-m zone include the 331 Building, the process ponds and trenches, the 324 Building, the 337 Building, the 337-B Building, the 338 Building and others (see Appendix D for excavation depths). 


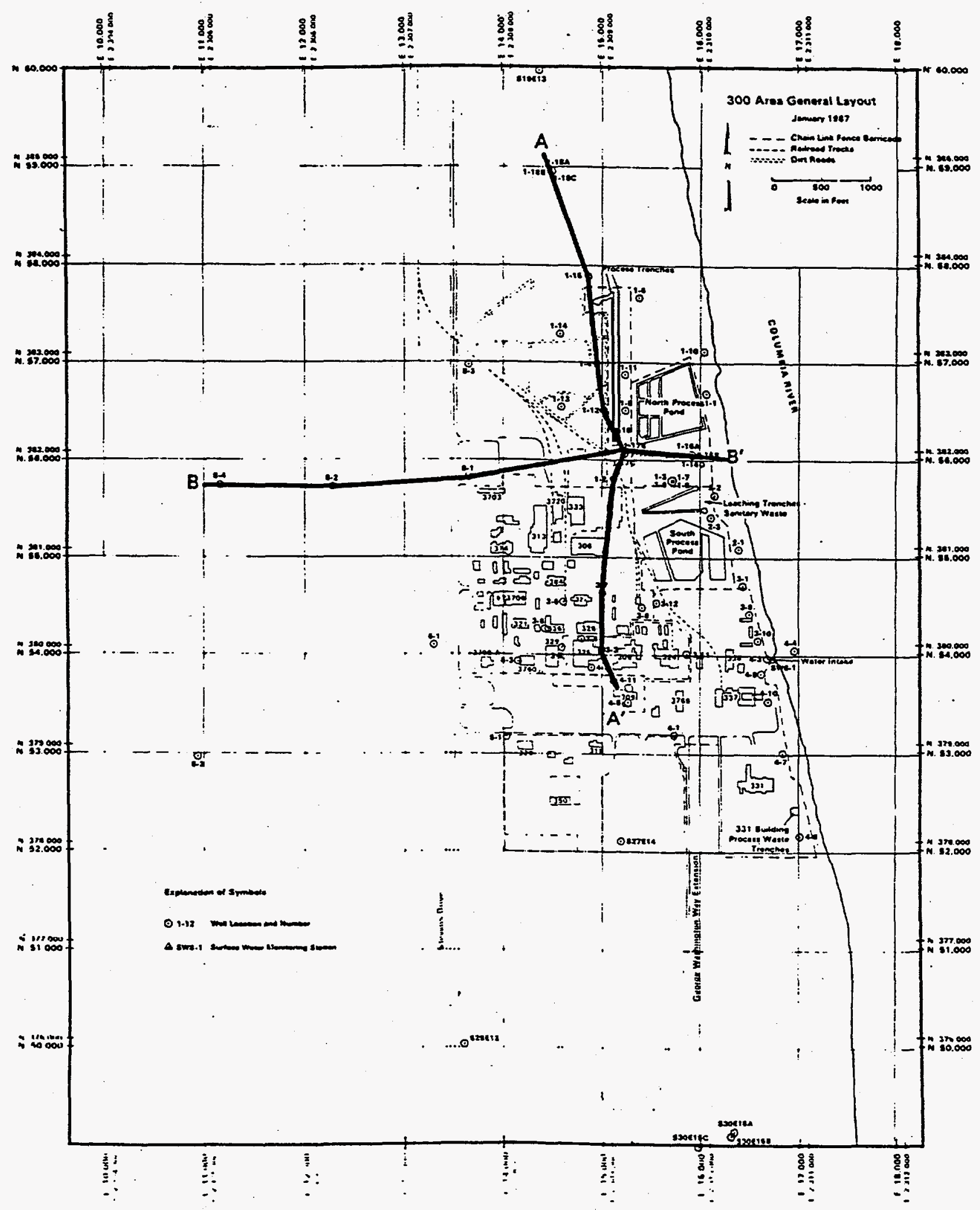

Figure 4.1. Location Map for Geologic Cross Sections in the 300 Area (after Schalla 1988) 

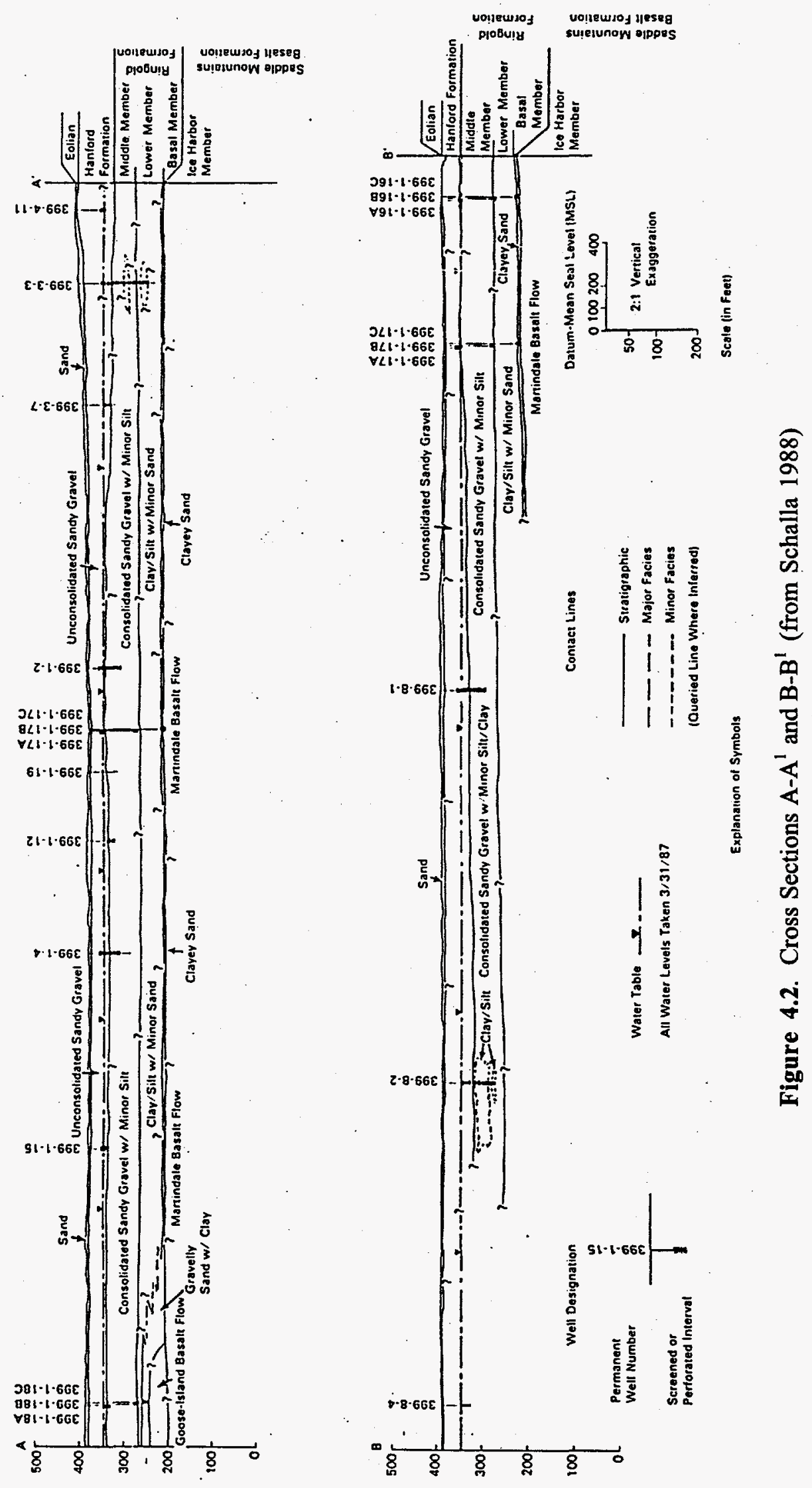

4.7 


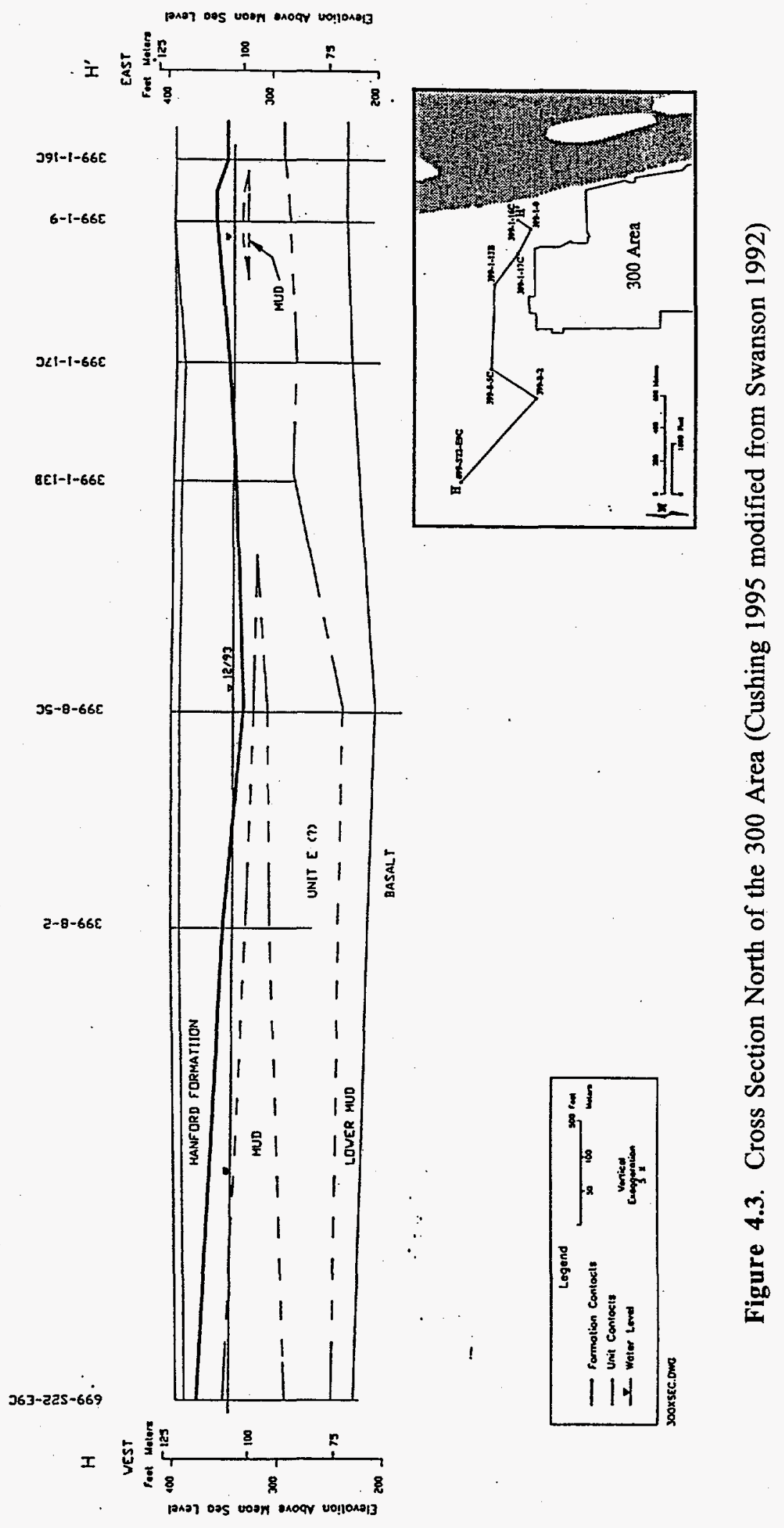

4.8 
Table 4.2. Information About Stratigraphy in Early 1940s Well Logs

\begin{tabular}{||l|l||}
\hline No. 1 Well & No. 2 Well \\
\hline Started drilling: $7-11-43$ & Started drilling: 1 $-08-44$ \\
\hline Finished drilling: $8-07-43$ & Finished drilling: $1-20-43$ \\
\hline Coordinates: N54514/E14608 & Coordinates: N54600/E15000 \\
\hline Formation Record: & Formation Record: \\
\hline $0^{\prime}-1^{\prime} \quad$ Top Soil & $0^{\prime}-20^{\prime} \quad$ Boulders and Gravel \\
\hline $1^{\prime}-4^{\prime} \quad$ Sand and Gravel & $20^{\prime}-47^{\prime} \quad$ Coarse Gravel \\
\hline $4^{\prime}-20^{\prime} \quad$ Cemented Gravel & $47^{\prime}-60^{\prime} \quad$ Boulders and Gravel \\
\hline $20^{\prime}-25^{\prime} \quad$ Washed - Sand and Gravel & $60^{\prime}-66^{\prime} \quad$ Coarse Gravel \\
\hline $25^{\prime}-38^{\prime} \quad$ Cemented Gravel & $66^{\prime}-81^{\prime}$ Boulders and Sand \\
\hline $38^{\prime}-49^{\prime} \quad$ Gravel & $81^{\prime}-86.7^{\prime}$ Clay \\
\hline $49^{\prime}-74^{\prime} \quad$ Washed Sand and Gravel & \\
\hline $74^{\prime}-85^{\prime} \quad$ Sand, Gravel and Clay & \\
\hline
\end{tabular}


Table 4.3. Buildings/Facilities Located Within the 400-Meter Zone of the Columbia River Including Demolished Buildings

\begin{tabular}{|c|c|}
\hline 308 & Plutonium Fuels Pilot Plant \\
\hline 331 & Life Sciences Laboratory \\
\hline $331 \mathrm{~A}$ & Virology Laboratory \\
\hline $331 \mathrm{~B}$ & Dog Kennel \\
\hline $331 \mathrm{E}$ & Greenhouse \\
\hline $331 \mathrm{~F}$ & Animal Resources Storage Facility \\
\hline $331 \mathrm{G}$ & Interim Tissue Repository \\
\hline $331 \mathrm{H}$ & Plant Exposure Facility/Aerosol Wind Tunnel \\
\hline $331 \mathrm{~J}$ & Incinerator \\
\hline 332 & Hazardous Waste Interim Holding Facility \\
\hline 335 & Fast Reactor Thermal Engineering Facility \\
\hline $335 \mathrm{~A}$ & Sodium Test Facility \\
\hline 336 & Core Segment Development Facility \\
\hline 337 & Technical Management Facility \\
\hline $337-\mathrm{B}$ & High Bay Service Wing, High-Temperature Sodium Facility \\
\hline $339 \mathrm{~A}$ & Computer Facility \\
\hline $340 \mathrm{~B}$ & Waste Load-Out Facility \\
\hline $352 \mathrm{E}$ & Switch Station East Side \\
\hline 3605 & Fence (circa 1943) \\
\hline 3607 & Sewage Treatment Septic Tank \\
\hline $3607 \mathrm{~A}$ & Chlorination Facility \\
\hline $3614 \mathrm{~A}$ & River Monitoring Station \\
\hline $3621 \mathrm{D}$ & Emergency Generator Building and Shop \\
\hline $3701 \mathrm{~S}$ & George Washington Guard Station \\
\hline $3707 \mathrm{~F}$ & Personnel Survey Building \\
\hline $3717 \mathrm{C}$ & Materials Archive Building \\
\hline $3718 \mathrm{C}$ & Storage Building \\
\hline $3718 \mathrm{E}$ & Storage Building \\
\hline $3718 \mathrm{~F}$ & Alkali Metal Treatment and Storage Facility \\
\hline $3718 \mathrm{G}$ & Storage Building \\
\hline $3718 \mathrm{M}$ & Sodium Storage Building \\
\hline 3727 & Classified Storage Facility \\
\hline 3728 & FFTF Test Article Storage Building/Geotechnical High Bay \\
\hline 3731 & Laboratory Equipment Central Pool \\
\hline $3731 \mathrm{~A}$ & Graphite Machine Shop \\
\hline 3763 & Office Building \\
\hline 3764 & Office \\
\hline 3765 & Office Building \\
\hline 3766 & Office \\
\hline 3767 & Office \\
\hline 3769 & Office \\
\hline 3770 & Office \\
\hline $3802 \mathrm{~A}$ & Steam Prv Station \\
\hline
\end{tabular}




\subsection{Conclusions}

A substantial amount of information exists about the excavation activities in the 300 Area. However, this information is not necessarily comprehensive. Historic documents, aerial photographs, and historic maps provide "big picture" information regarding the planning, development, and impacts of construction activities through time in the 300 Area. Location specific documents or studies such as engineer drawings, well logs, and remote sensing studies provide information about the extent of excavations for building foundations and basements, and the presence of Holocene deposits at discrete locations. (Remote sensing studies conducted in the 300 Area have shown that engineer drawings or maps depicting underground features do not always accurately reflect the exact location of buried features or excavations.)

Historic photographs of construction activities provide an avenue to determine the scale of many excavations and often depict secondary or indirect impacts associated with excavations that are often not considered such as impacts associated with equipment parking, covering the original landscape with excavated backfill, or temporary road construction.

\subsection{Areas of Disturbance}

Four GIS maps were created to display known areas of disturbance in the 300 Area. These maps contain information gleaned from a variety of sources but the primary sources, include the Hanford GIS database system, engineer drawings, and historic maps (Figures 5.1 through 5.4).

In addition to these maps, several assumptions can be made about areas of disturbance in the 300 Area as a result of this study:

- Buried pipelines are not always located where they are mapped. As a result, cultural resource monitors or specialists should not depend on maps depicting subsurface pipelines for accurate locations of previous disturbance (Sandness 1991).

- Temporary roads built in the early 1940s were placed on layers of sand and gravel 8 to 12 in. thick. Given this information, it is likely that substrates beneath these early roads are only minimally disturbed.

- Building foundations ranged from concrete slabs no more that 6 to 8 in. thick to deeply excavated pits and basements. Buildings constructed with slab foundations are more numerous than may be expected, and minimally disturbed substrates may be expected in these locations.

- Historic black and white photographs provide a partial record of some excavations, including trenches, building basements, and material lay-down yards. Estimates of excavation depth and width can be made, but these estimates are not accurate enough to pinpoint the exact location where the disturbed/undisturbed interface is located (e.g., camera angles were such that depths and/or widths of excavations could not be determined or estimated). In spite of these limitations, these photographs provide essential information. 


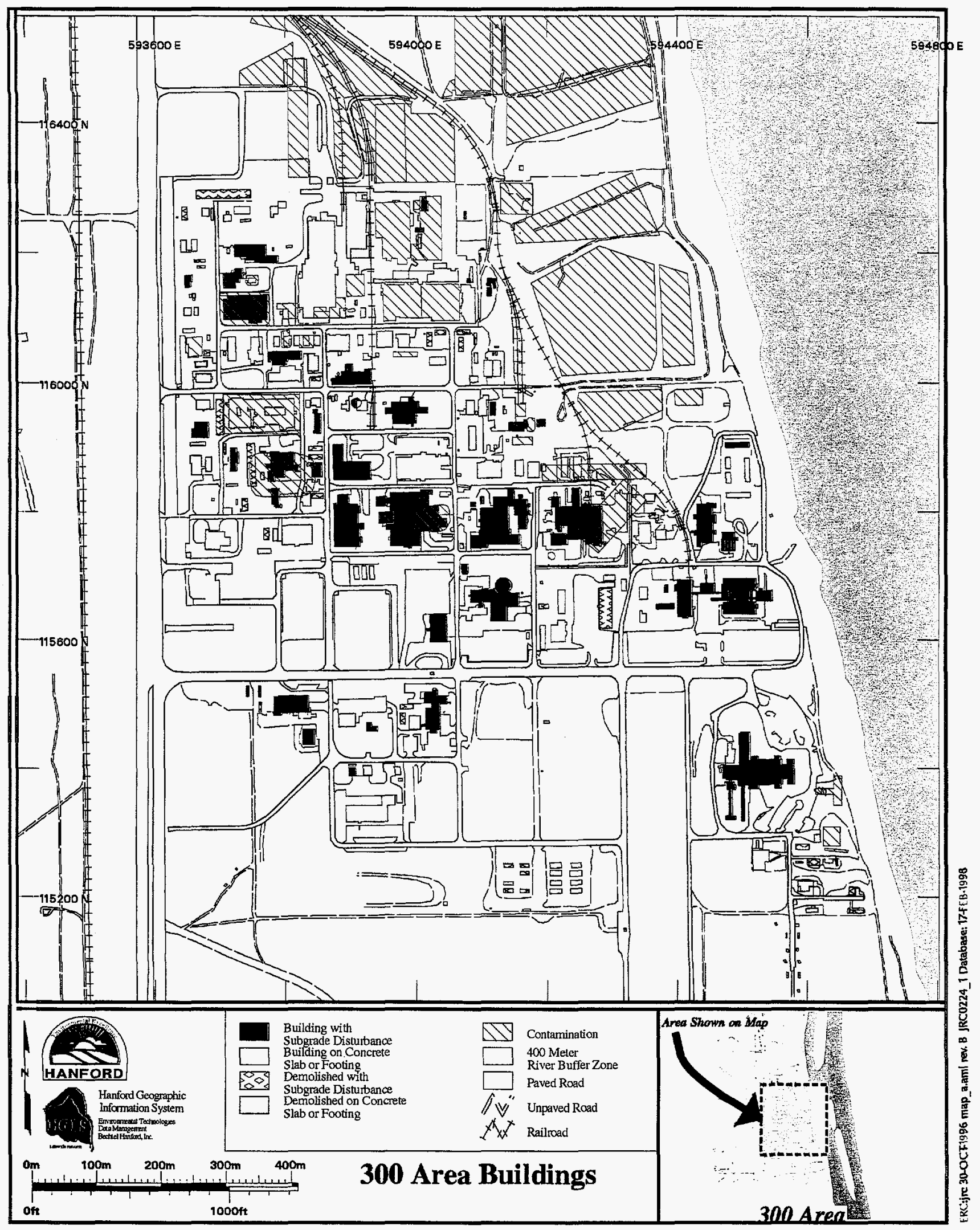

Figure 5.1. Buildings and Their Patterns of Disturbance in the 300 Area 


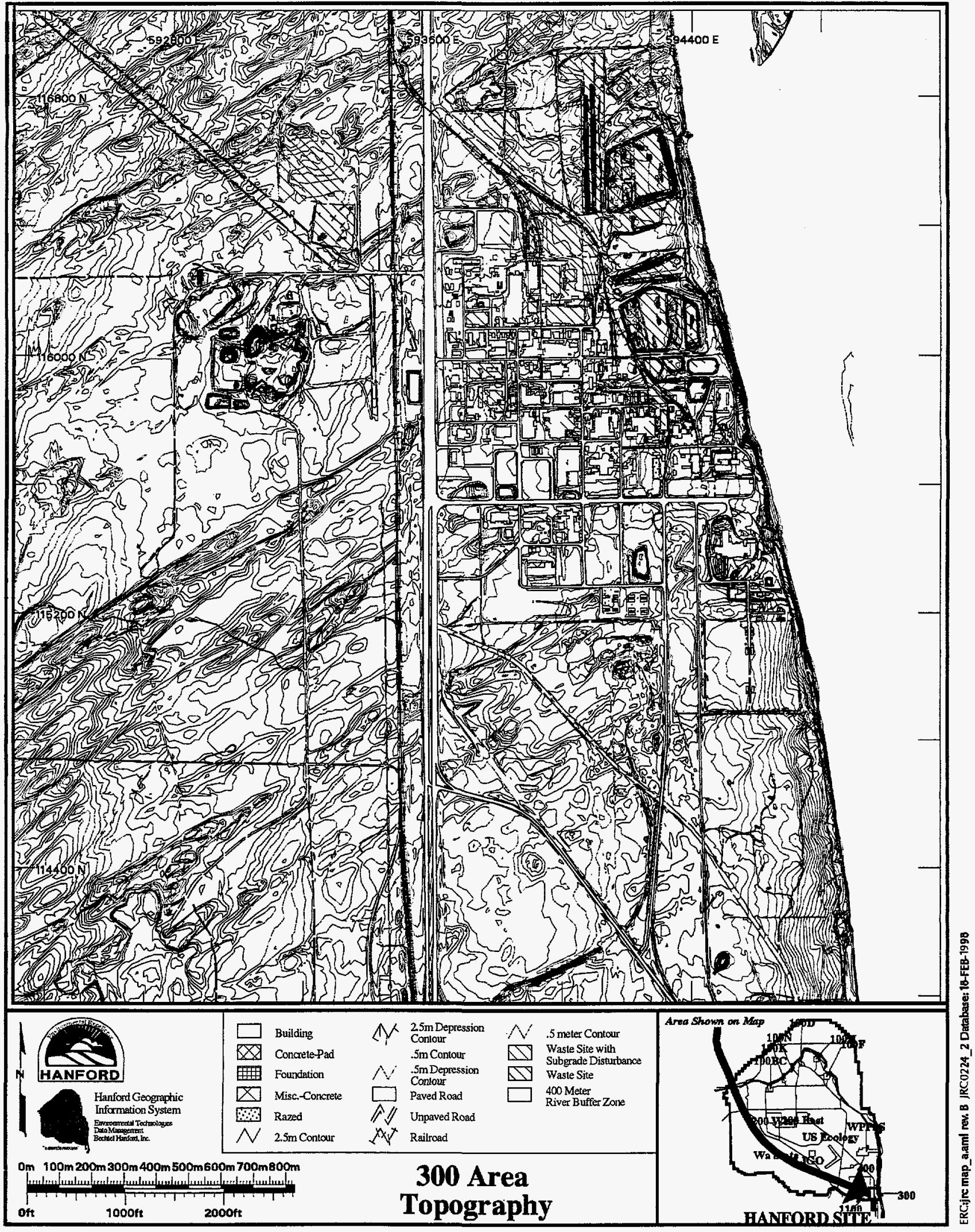

Figure 5.2. The Modern Topography of the General 300 Area as Recorded in the Sitewide GIS Database 


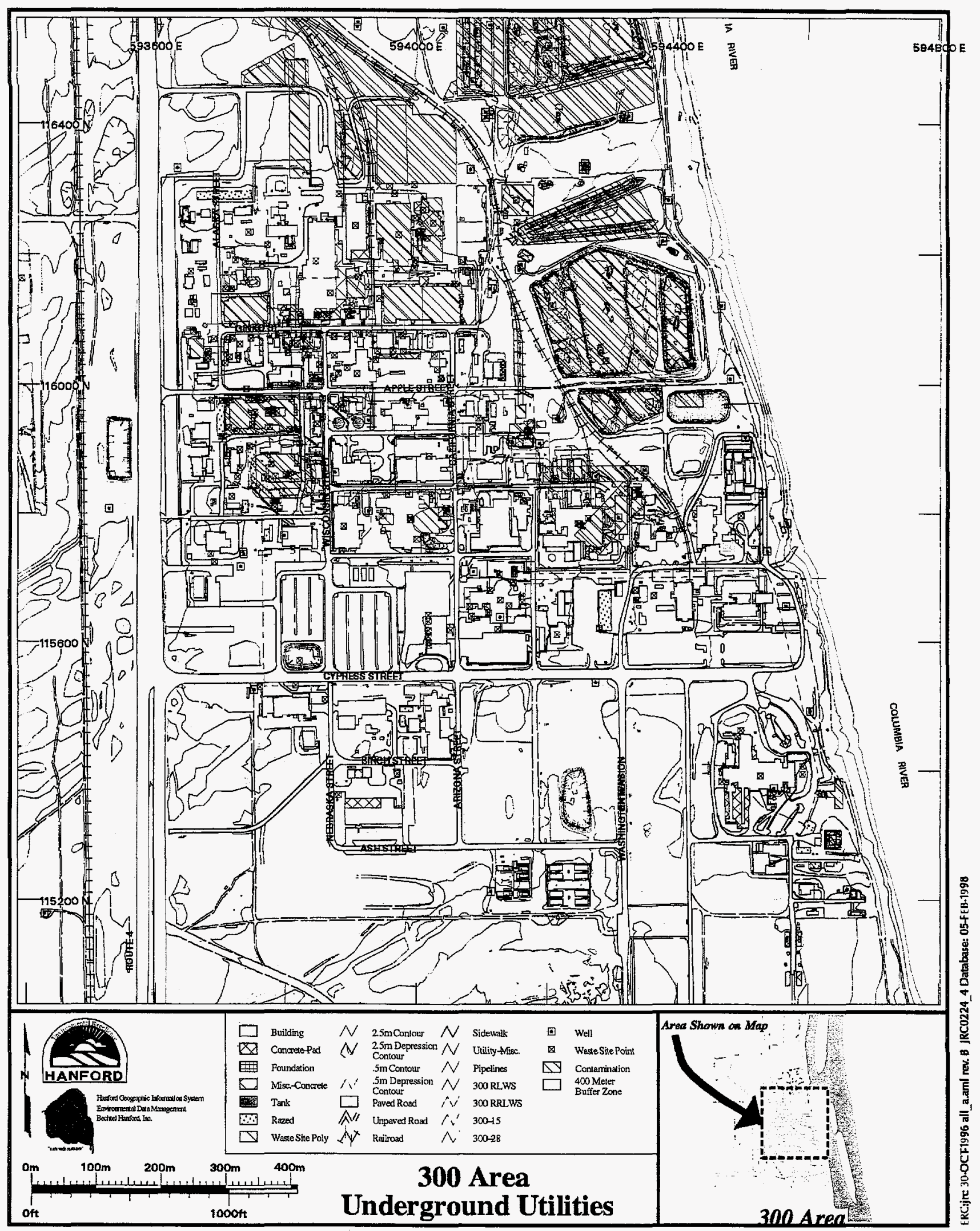

Figure 5.3. Underground Facilities as Recorded in the Sitewide GIS Database 


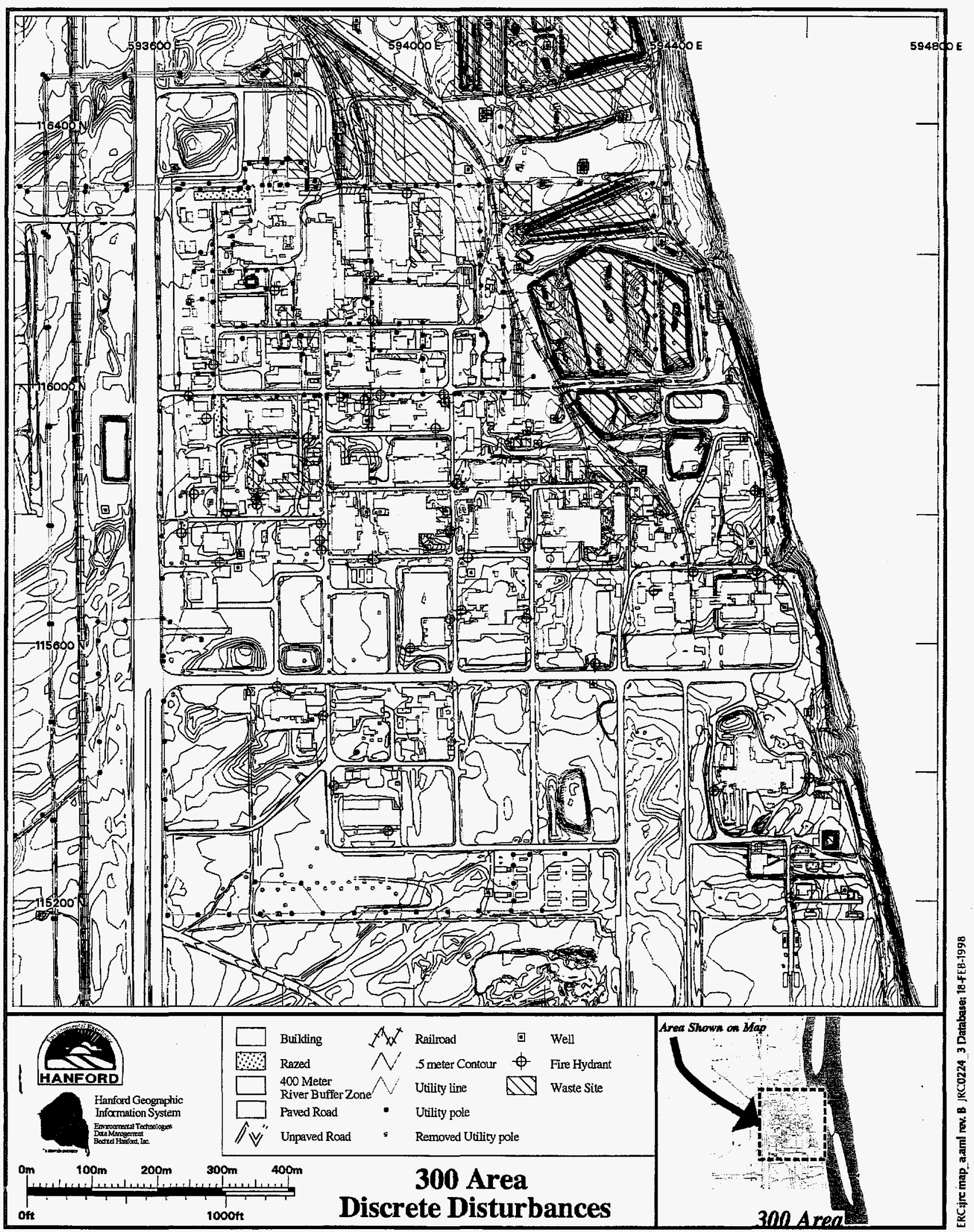

Figure 5.4. Areas of Discrete Disturbance Throughout the 300 Area as Recorded in the Sitewide GIS Database 
- Aerial and historic low-level photographs have captured what appears to be backfill throughout much of the eastern portion of the 300 Area-near the Columbia River shoreline. This layer of fill has likely afforded some protection for the natural landscape buried beneath the fill. This assumption fits nicely with the intermittent and inadvertent discoveries of hearths and stone tools documented through the years in this part of the 300 Area. Conversely, leveling of sand dunes appears to be substantial in the northwestern portion of the 300 Area during the early stages of development.

- Project files and engineer drawings do not contain information on any impromptu but necessary adjustments made on the ground during project implementation-after the design phase. Further, many projects are planned and mapped but never implemented-this information is also not often placed in project files.

\subsection{Recommendations For Future Study}

Several actions can be taken to refine our knowledge about previously disturbed areas located in the 300 Area, as outlined below.

- Initiate research into previous project files from the early 1940 s to the present time to define excavation dimensions for all 300 Area projects.

- Take GPS (differentially corrected) points of previous disturbance encountered in ongoing excavations as evidenced by inspection of trench walls.

- Record the dimensional extent and location of monitored excavations in the 300 Area.

In addition to refining our knowledge about areas of previous disturbance in the 300 Area, we can use existing data to provide guidelines for the creation of a cost-effective monitoring program for cultural resources. Specific areas of disturbance can be clearly defined for the following: building footprints, roads, railroad grades, pipelines, utility poles, wells, and fire hydrants. It is suggested that monitoring is not necessary in these areas of previous disturbance when they are located outside the 400-m zone located along the Columbia River. Specific monitoring recommendations are identified in Table 5.1.

Table 5.1. Monitoring Recommendations for Excavation Activities in Specific Areas

\begin{tabular}{||l|l|l||}
\hline \multicolumn{1}{|c|}{ GIS Map } & \multicolumn{1}{|c|}{ Map Feature } & \multicolumn{1}{c|}{ Monitoring Recommendations } \\
\hline \hline Figure 5.1 300 Area \\
Buildings & $\begin{array}{l}\text { Building Footprint with } \\
\text { Sub-grade Disturbance }\end{array}$ & $\begin{array}{l}\text { Monitoring not Required In Disturbance } \\
\text { Footprint Outside 400-m Zone. Monitoring } \\
\text { Required Inside 400-m Zone. }\end{array}$ \\
\hline & $\begin{array}{l}\text { Building Footprint on } \\
\text { Concrete Slab or Footing }\end{array}$ & $\begin{array}{l}\text { Monitoring Required Inside 400-m Zone. } \\
\text { Intermittent Monitoring Outside 400-m Zone. }\end{array}$ \\
\hline & $\begin{array}{l}\text { Demolished Building } \\
\text { Footprint with Sub-grade } \\
\text { Disturbance }\end{array}$ & $\begin{array}{l}\text { Monitoring not Required In Disturbance } \\
\text { Footprint Outside 400-m Zone. Monitoring } \\
\text { Required Inside 400-m Zone. }\end{array}$ \\
\hline & $\begin{array}{l}\text { Demolished Building } \\
\text { Footprint on Concrete Slab } \\
\text { or Footing }\end{array}$ & $\begin{array}{l}\text { Monitoring not Required In Disturbance } \\
\text { Footprint Outside 400-m Zone. Monitoring } \\
\text { Required Inside 400-m Zone. }\end{array}$ \\
\hline
\end{tabular}


Table 5.1. (contd)

\begin{tabular}{|c|c|c|}
\hline GIS Map & Map Feature & Monitoring Recommendations \\
\hline \multirow[t]{5}{*}{$\begin{array}{l}\text { Figure 5.1 } 300 \text { Area } \\
\text { Buildings }\end{array}$} & Paved Road & $\begin{array}{l}\text { Monitoring not Required In Disturbance } \\
\text { Footprint Outside } 400-\mathrm{m} \text { Zone. Monitoring } \\
\text { Required Inside } 400-\mathrm{m} \text { Zone. }\end{array}$ \\
\hline & Unpaved Road & $\begin{array}{l}\text { Monitoring not Required In Disturbance } \\
\text { Footprint Outside } 400-\mathrm{m} \text { Zone. Monitoring } \\
\text { Required Inside } 400-\mathrm{m} \text { Zone. }\end{array}$ \\
\hline & Railroad & $\begin{array}{l}\text { Monitoring not Required In Disturbance } \\
\text { Footprint Outside } 400-\mathrm{m} \text { Zone. Monitoring } \\
\text { Required Inside } 400-\mathrm{m} \text { Zone. }\end{array}$ \\
\hline & $400 \mathrm{~m}$ Zone & Monitoring Required. \\
\hline & White Areas of Map & $\begin{array}{l}\text { Monitoring To Be Determined on a Case-By- } \\
\text { Case Basis. }\end{array}$ \\
\hline \multirow[t]{11}{*}{$\begin{array}{l}\text { Figure 5.3 } 300 \text { Area } \\
\text { Underground } \\
\text { Utilities } \\
\end{array}$} & Sidewalk & $\begin{array}{l}\text { Monitoring not Required In Disturbance } \\
\text { Footprint Outside } 400-\mathrm{m} \text { Zone. Monitoring } \\
\text { Required Inside } 400-\mathrm{m} \text { Zone. }\end{array}$ \\
\hline & Miscellaneous Pipeline & $\begin{array}{l}\text { Monitoring not Required In Disturbance } \\
\text { Footprint Outside } 400-\mathrm{m} \text { Zone. Monitoring } \\
\text { Required Inside } 400-\mathrm{m} \text { Zone. }\end{array}$ \\
\hline & 300 RLWS (Contaminated) & To Be Determined. \\
\hline & 300 RRLWS (Contaminated) & To Be Determined. \\
\hline & 300-15 (Contaminated) & To Be Determined. \\
\hline & $300-28$ (Contaminated) & To Be Determined. \\
\hline & Well & $\begin{array}{l}\text { Monitoring not Required In Disturbance } \\
\text { Footprint Outside } 400-\mathrm{m} \text { Zone. Monitoring } \\
\text { Required Inside } 400-\mathrm{m} \text { Zone. }\end{array}$ \\
\hline & Waste Site Point & To Be Determined. \\
\hline & Contamination Zones & To Be Determined. \\
\hline & $400 \mathrm{~m}$ Zone & Monitoring Required. \\
\hline & White Areas of Map & $\begin{array}{l}\text { Monitoring To Be Determined on a Case-By- } \\
\text { Case Basis. }\end{array}$ \\
\hline \multirow[t]{5}{*}{$\begin{array}{l}\text { Figure } 5.4300 \text { Area } \\
\text { Discrete } \\
\text { Disturbances } \\
\end{array}$} & Utility Pole & $\begin{array}{l}\text { Monitoring not Required in Disturbance } \\
\text { Footprint Outside } 400-\mathrm{m} \text { Zone. Monitoring } \\
\text { Required Inside } 400-\mathrm{m} \text { Zone. }\end{array}$ \\
\hline & Removed Utility Pole & $\begin{array}{l}\text { Monitoring not Required In Disturbance } \\
\text { Footprint Outside } 400-\mathrm{m} \text { Zone. Monitoring } \\
\text { Required Inside } 400-\mathrm{m} \text { Zone. }\end{array}$ \\
\hline & Well & $\begin{array}{l}\text { Monitoring not Required In Disturbance } \\
\text { Footprint Outside } 400-\mathrm{m} \text { Zone. Monitoring } \\
\text { Required Inside } 400-\mathrm{m} \text { Zone. }\end{array}$ \\
\hline & Fire Hydrant & $\begin{array}{l}\text { Monitoring not Required In Disturbance } \\
\text { Footprint Outside } 400-\mathrm{m} \text { Zone. Monitoring } \\
\text { Required Inside } 400-\mathrm{m} \text { Zone. }\end{array}$ \\
\hline & White Areas of Map & $\begin{array}{l}\text { Monitoring To Be Determined on a Case-By- } \\
\text { Case Basis. }\end{array}$ \\
\hline
\end{tabular}




\subsection{References}

Chatters, J. C. 1989. Hanford Cultural Resources Management Plan. PNL-6942, Pacific Northwest Laboratory, Richland, Washington.

Cushing, C. E. 1995. Hanford Site National Environmental Policy Act (NEPA) Characterization. PNL-6415, Pacific Northwest Laboratory, Pullman, Washington.

DuPont. 1945. Construction Hanford Engineer Works: History of the Project. HN-10970, U.S. Contract No. W-7412-ENG-1, Du Pont Project 9536, Vol. 4. E. I. Dupont De Nemours and Co., Wilmington, Delaware.

Gerber, M. S. 1993. Manhattan Project Buildings and Facilities at the Hanford Site: A Construction History. WHC-MR-0425, Westinghouse Hanford Company, Richland, Washington.

Relander, C. 1986. Drummers and Dreamers. Caxton Printers, Ltd., Seattle, Washington.

Rice, D. G. 1985. Archaeological Survey of a Potential Barge Unloading Site at the 300 Area at Hanford. Westinghouse Hanford Company, manuscript on file at Pacific Northwest National Laboratory, Richland, Washington.

Sandness, G. A. 1991. Report on Geophysical Surveys in the 300-FF-1 Operable Unit. EMO-1032, Environmental Management Operations, Battelle Memorial Institute, Richland, Washington.

Schalla, R. 1988. Interim Characterization Report for the 300 Area Process Trenches. PNL-6716, Pacific Northwest Laboratory, Richland, Washington.

United States Atomic Energy Commission (USAEC). 1943. Project Ownership Map. Hanford Operations, Washington.

United States Department of Energy (DOE). 1996. Programmatic Agreement Among the U.S. Department of Energy Richland Operations Office, The Advisory Council on Historic Preservation, and The Washington State Historic Preservation Office for the Maintenance Deactivation Alternation, and Demolition of the Built Environment on the Hanford Site, Washington, DOE-RL, Richland, Washington.

United States Geological Survey (USGS). 1930. Upper Columbia River Snake River to International Boundary Index to Aerial Photos Section "A". Flown by Brubaker for USGS, March 1930.

Young J. S., and J. S. Fruchter. 1991. Addendum to Data Compilation Task Report for the Source Investigation of the 300-FF-1 Operable Unit Phase 1 Remedial Investigations. Environmental Management Operations, Pacific Northwest National Laboratory, Richland, Washington. 


\section{Appendix A}

\section{Area: Geophysical Survey Maps}




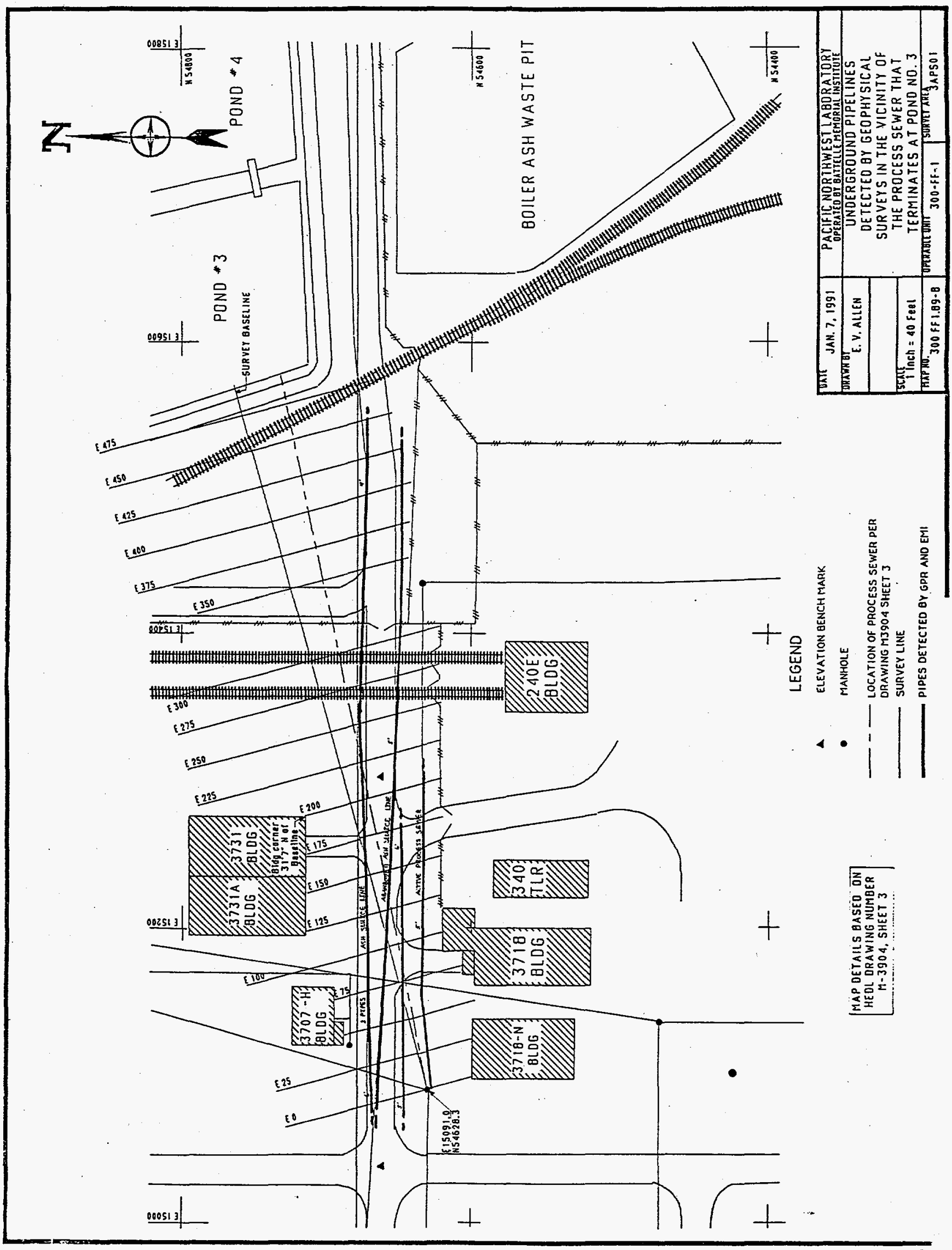




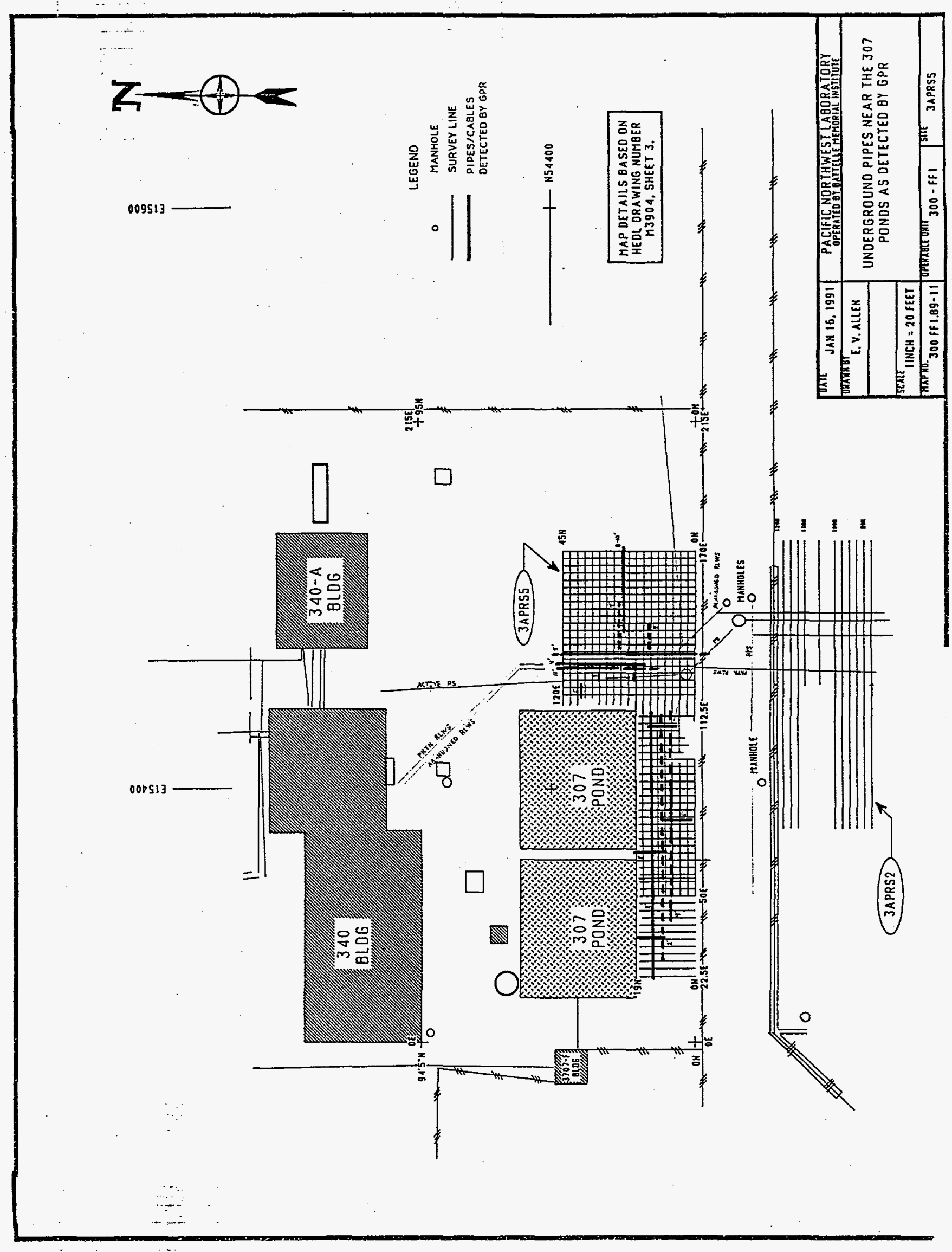




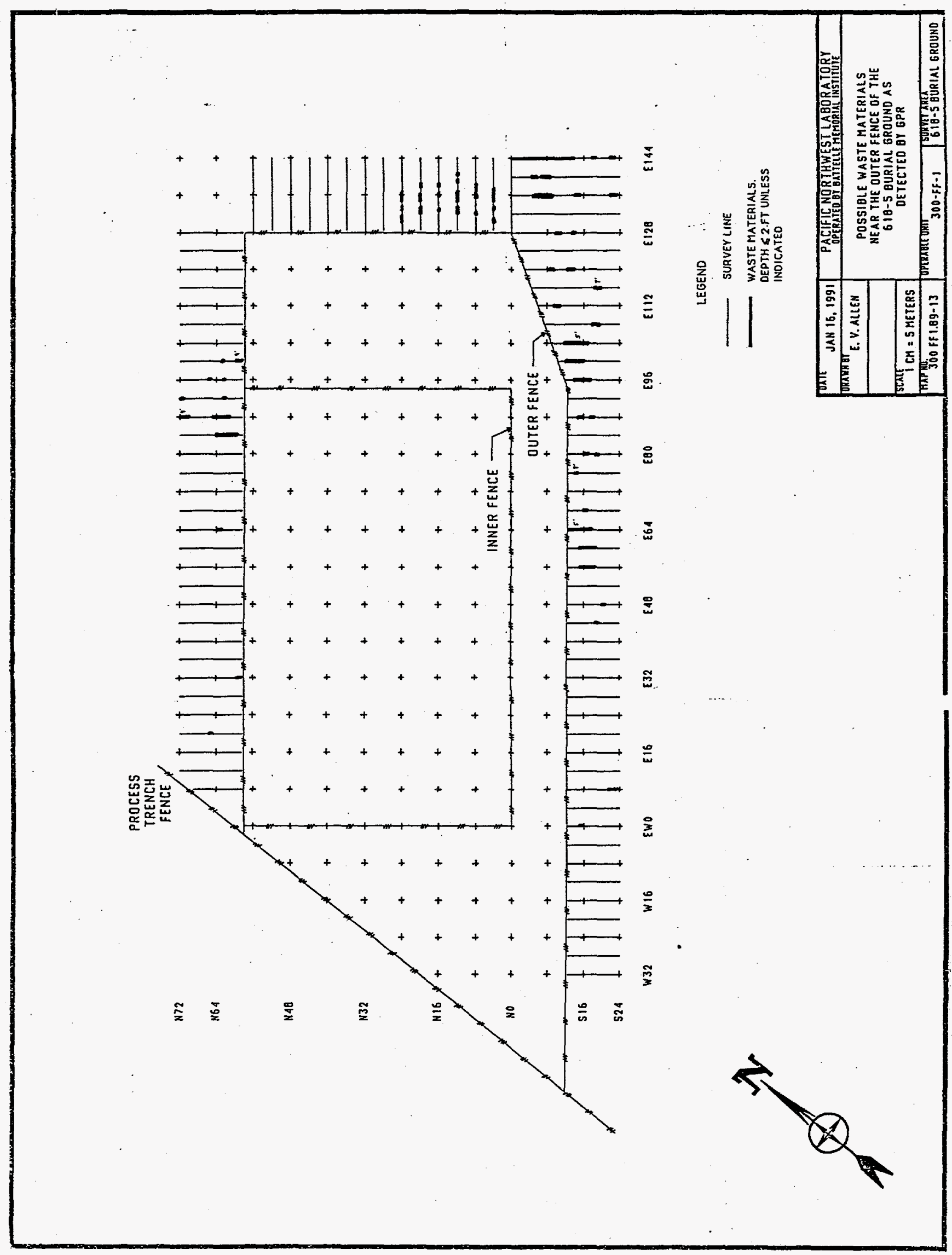




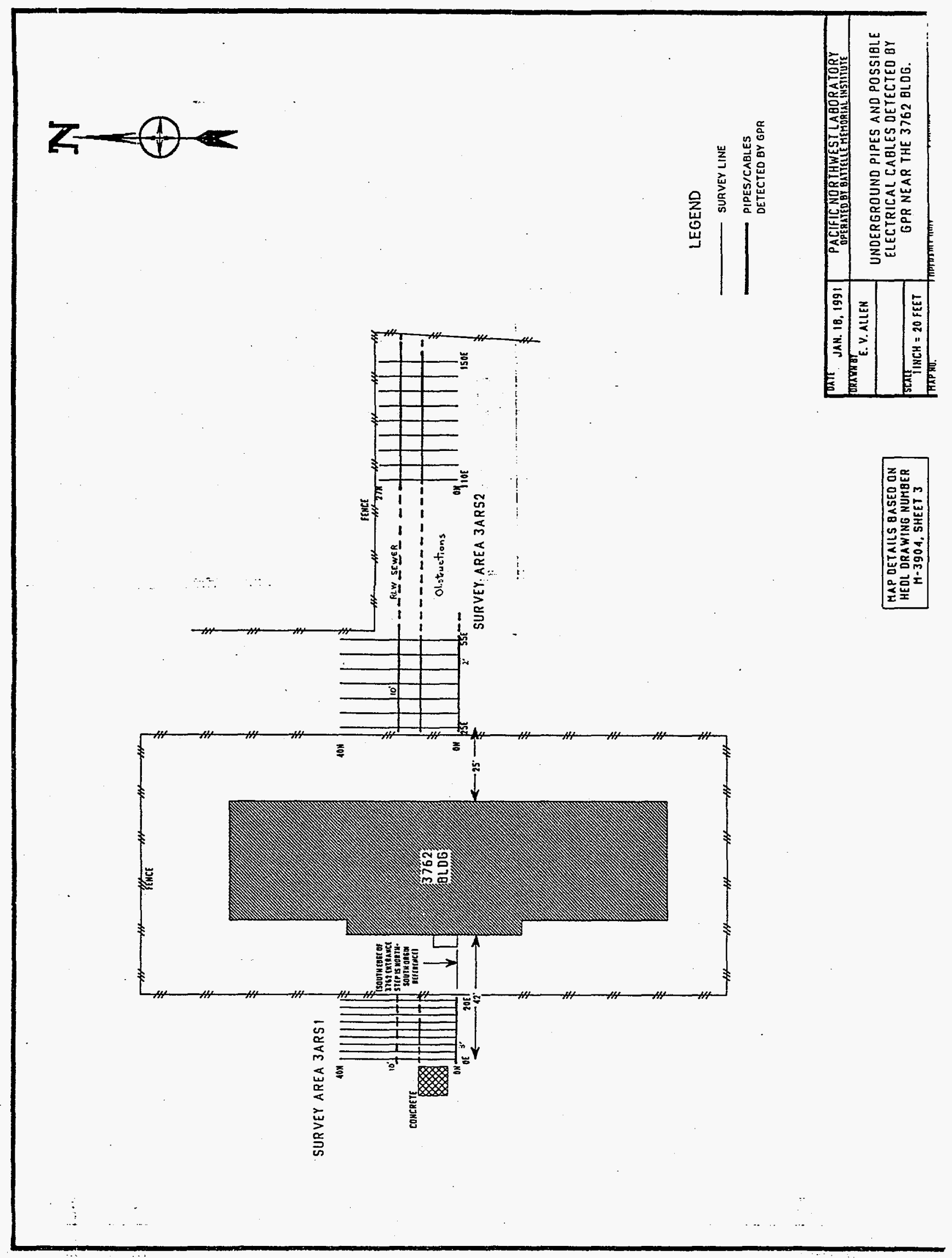




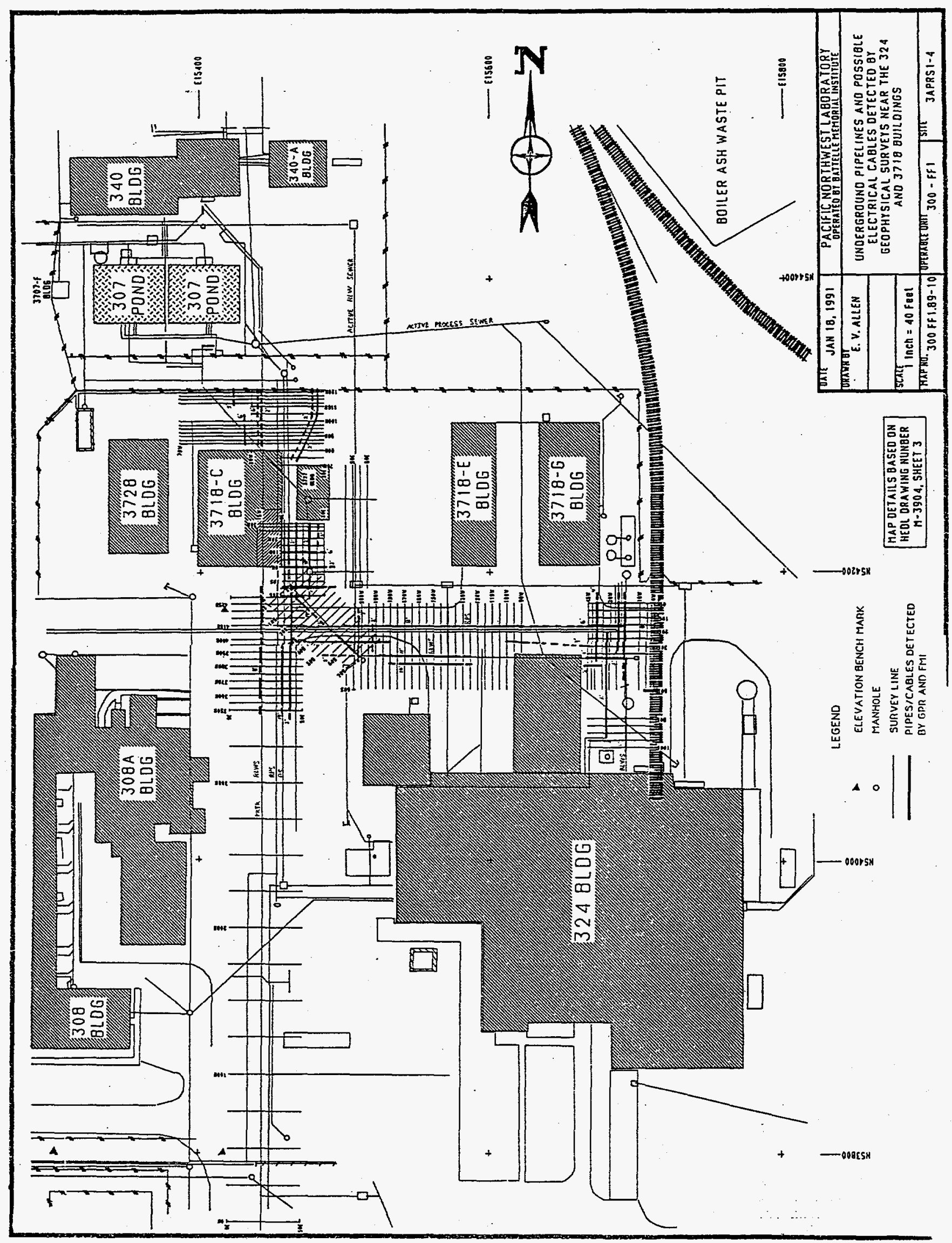




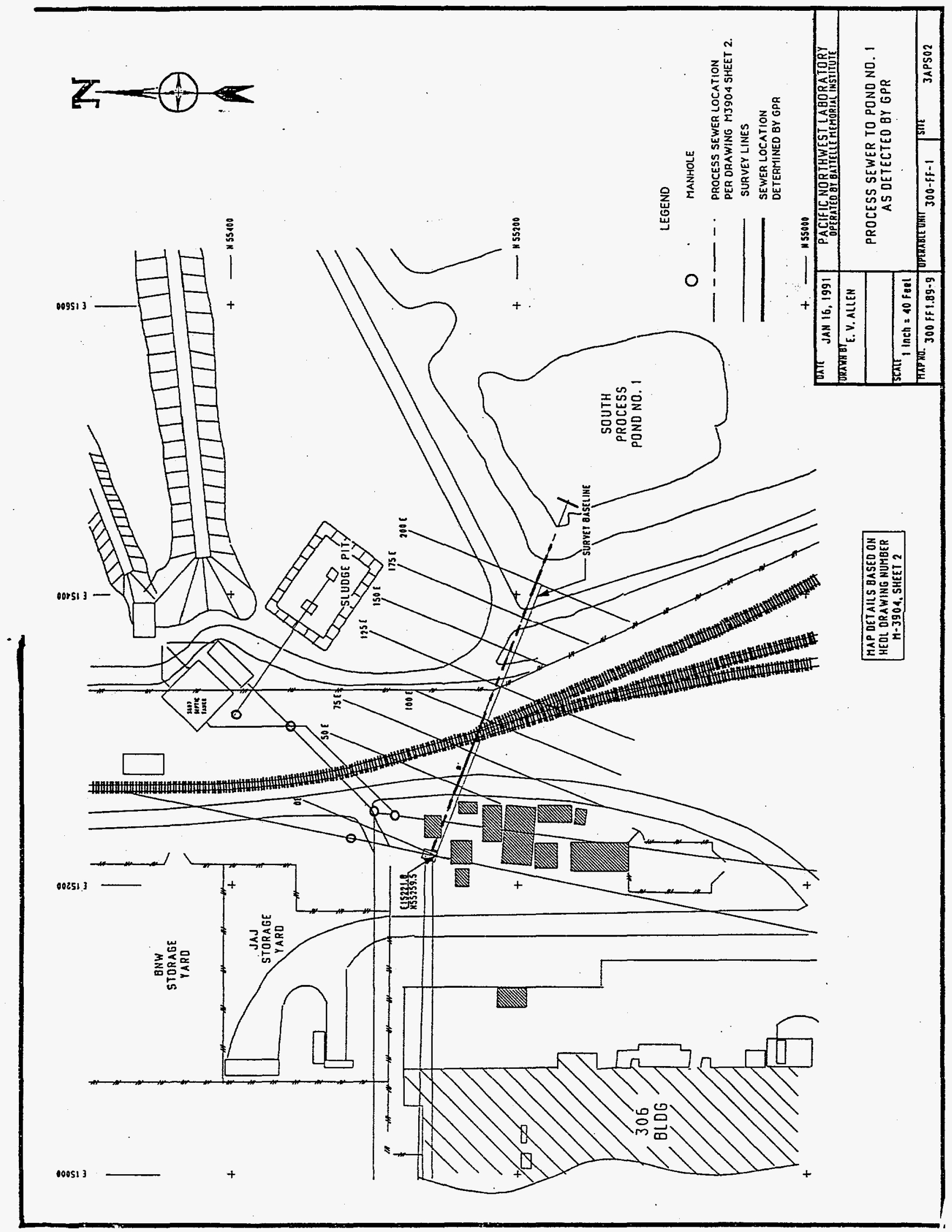




\section{Appendix B}

300 Area: Photographs 


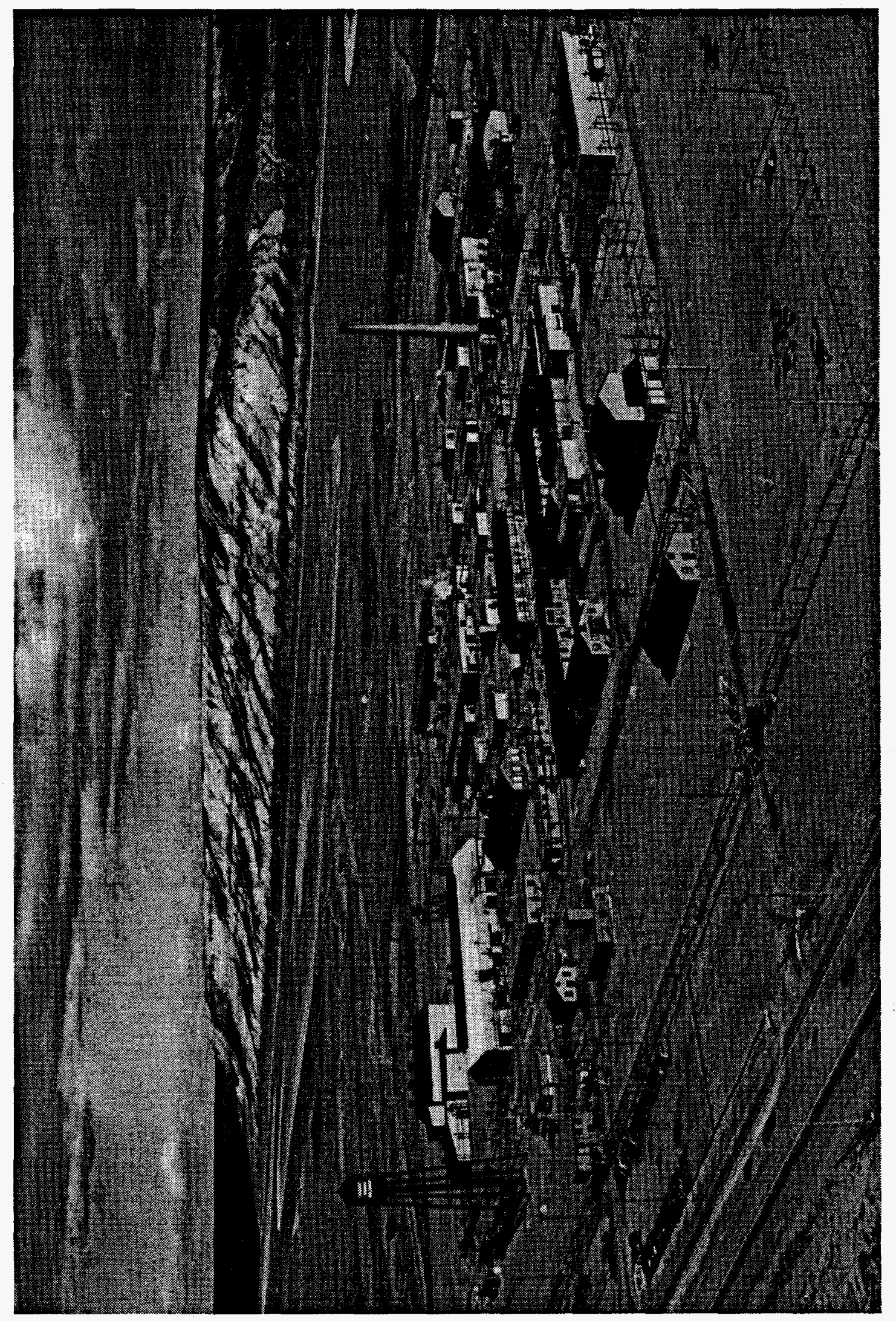

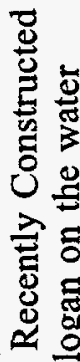

告

$\sum^{\pi}$

兘

8

艺造

궁융

踏

ธิ

造

उ。

농

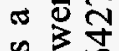

家

的娄

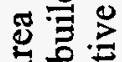

<鬲

品总

눙

它完

远焉

\&

요

$\Xi$.

들

高芒

$F$ 可

들.

ㄴ.

융 뽄

的

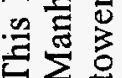

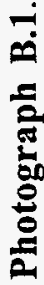

B.1 


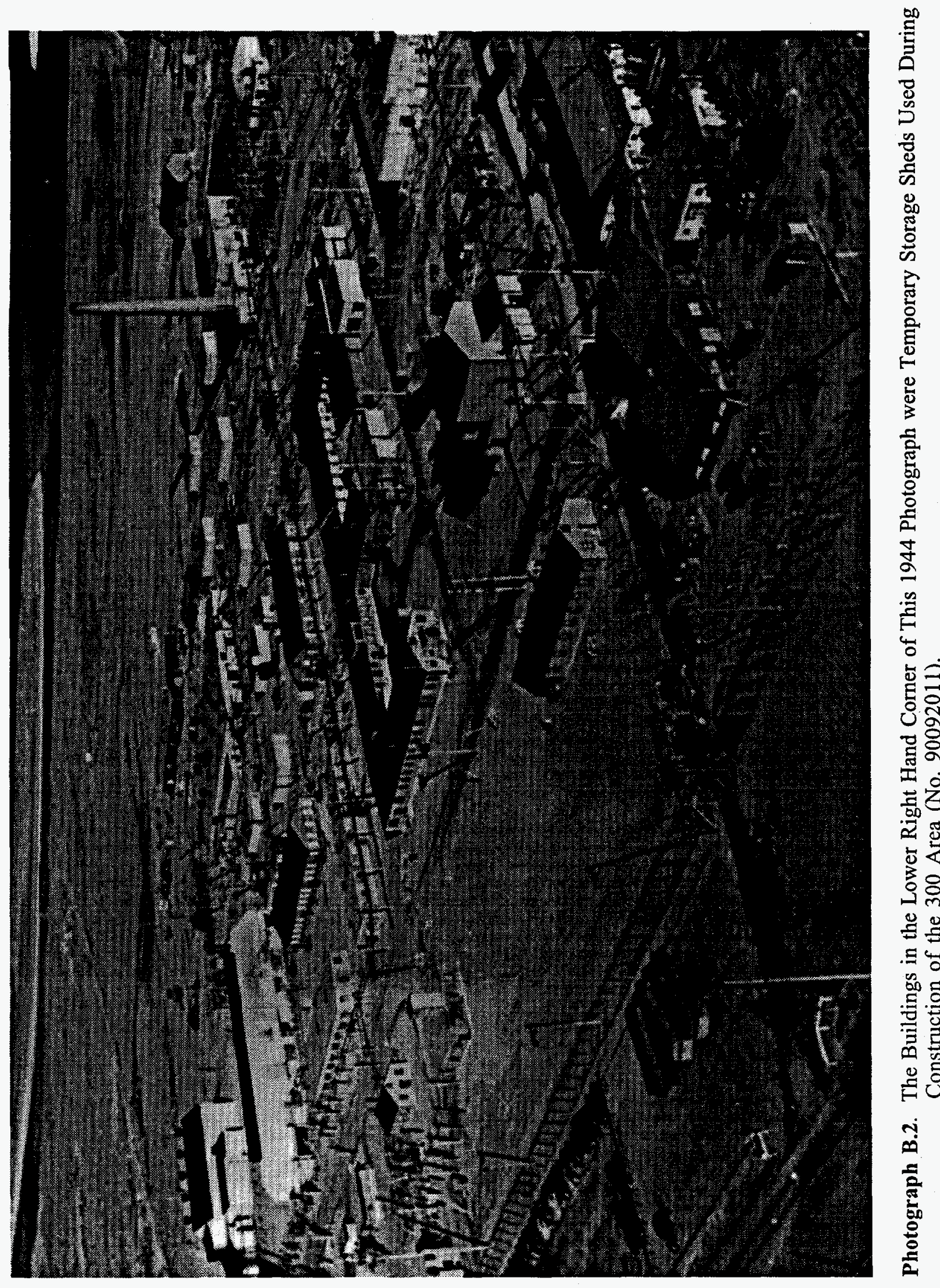

B. 2 


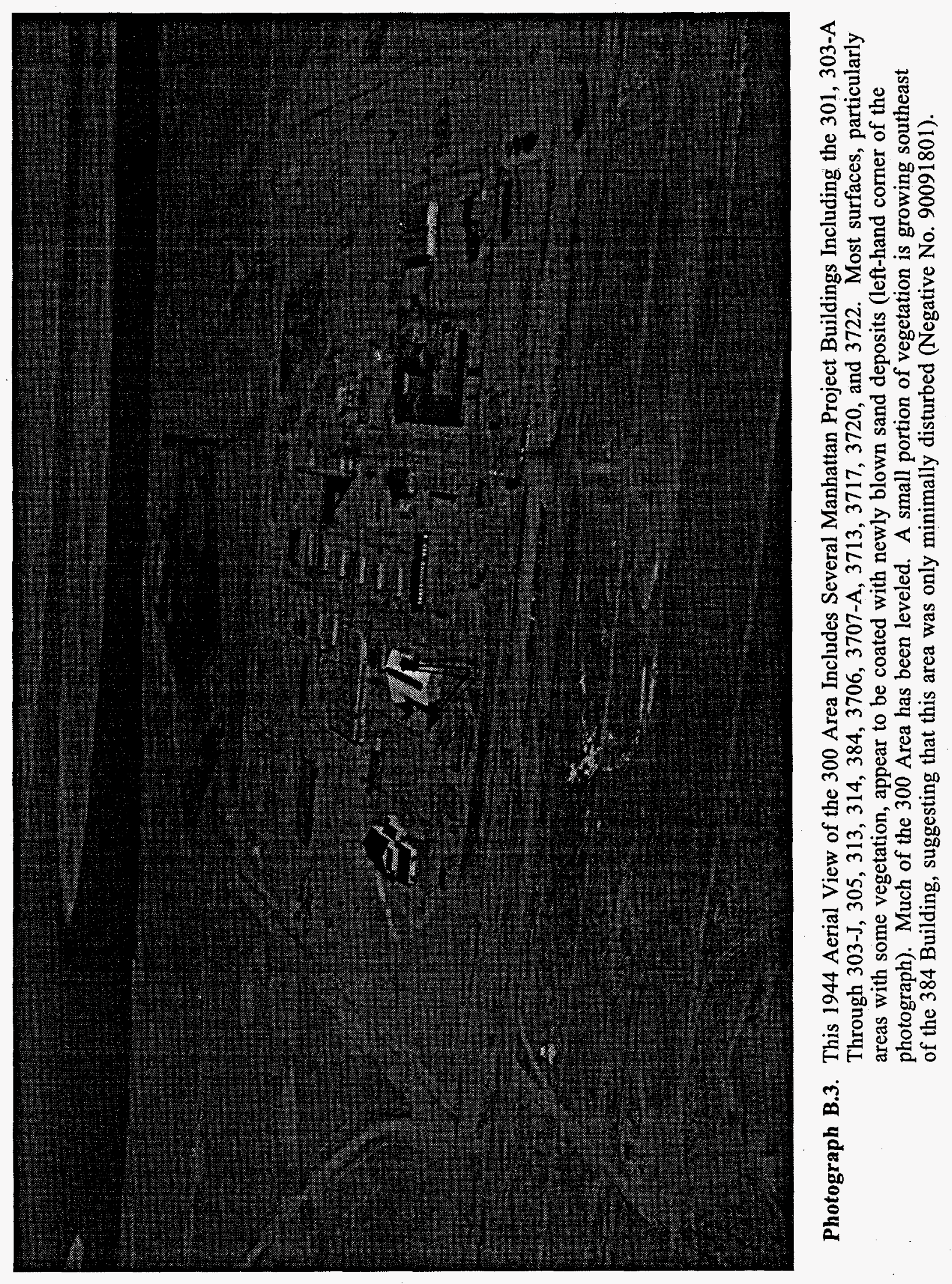

B. 3 


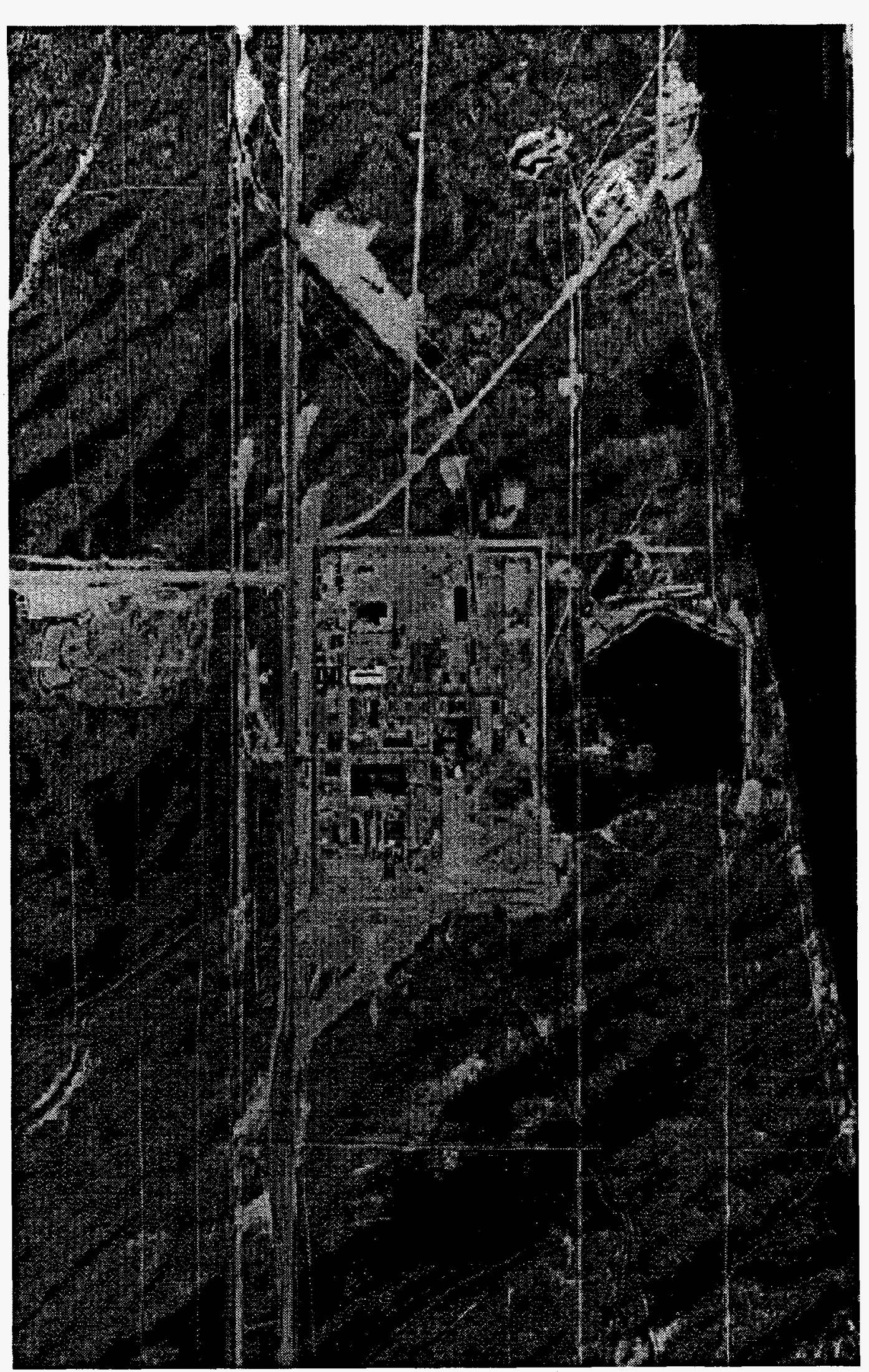

㩆

푱ㄹㄹ

这歌

운을

$8 \% 0$

Ð

要告

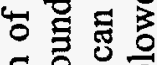

든 0

之

刃용

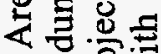

뭉

올

클

马्ञ

क्ष

目非。

융

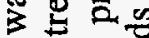

$\infty>0 \%$

흘

西 嗮

ต

m

ษ 8 ठิ่

$=\mathrm{m}$ 공요

텽넝 평용 考边 윅 웅 0 0

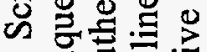
킬을 .

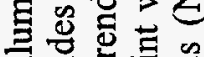
之定焉导

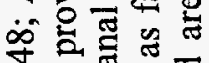
可

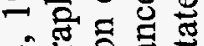
岕雚.

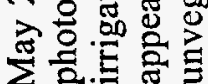

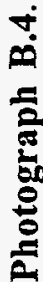




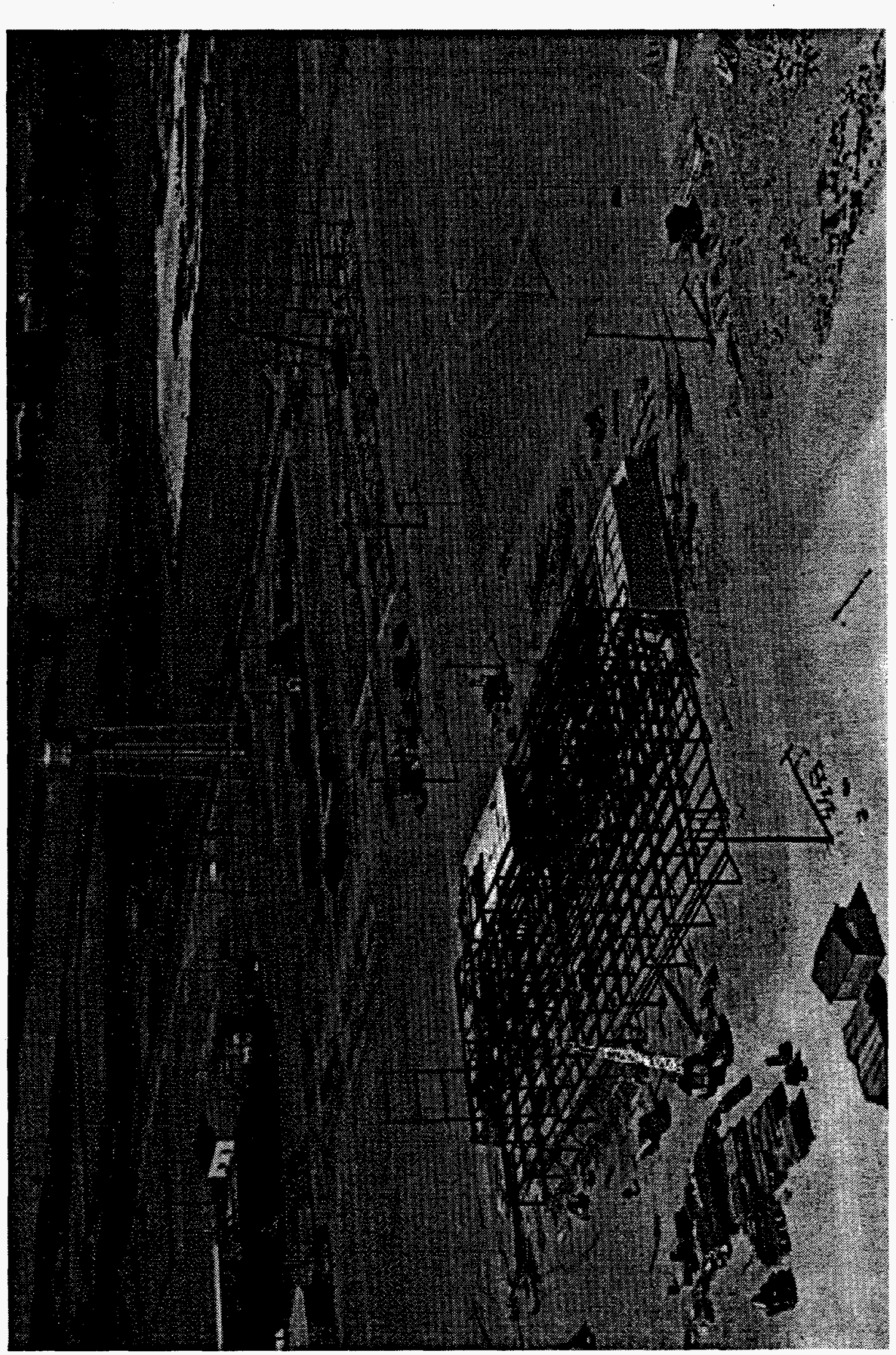

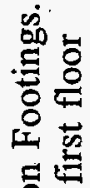

总吾

音

官

훙.

过

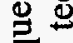

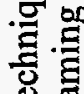

过

플 ㅇํํ

"

E⿱

형ㅇㅇㅇ

政

.0

훙 矛

口

敌已

政

응

ㅁ

त्ञ

๙2

o

卷宕

4 .

$\circ$.

을 흉

잉

ț $\mathrm{m}$

玟 3

\&

옹

可

จे

ल 능 舟

을

范 $\leqq 4$

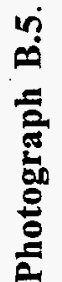

\section{B. 5}




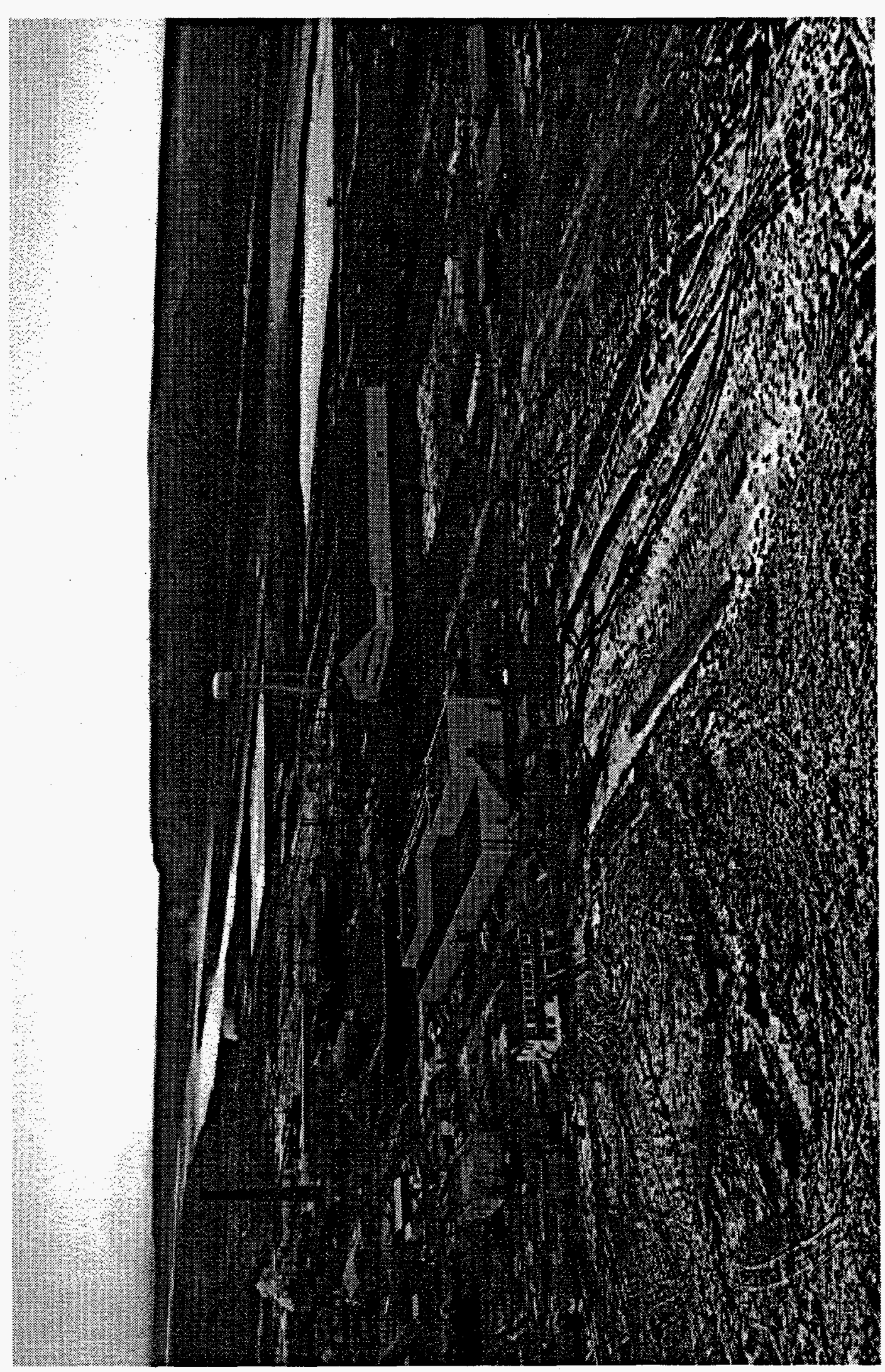

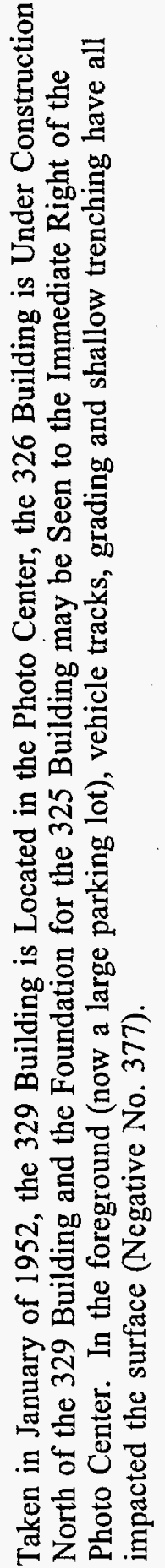

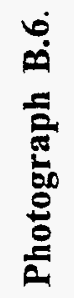




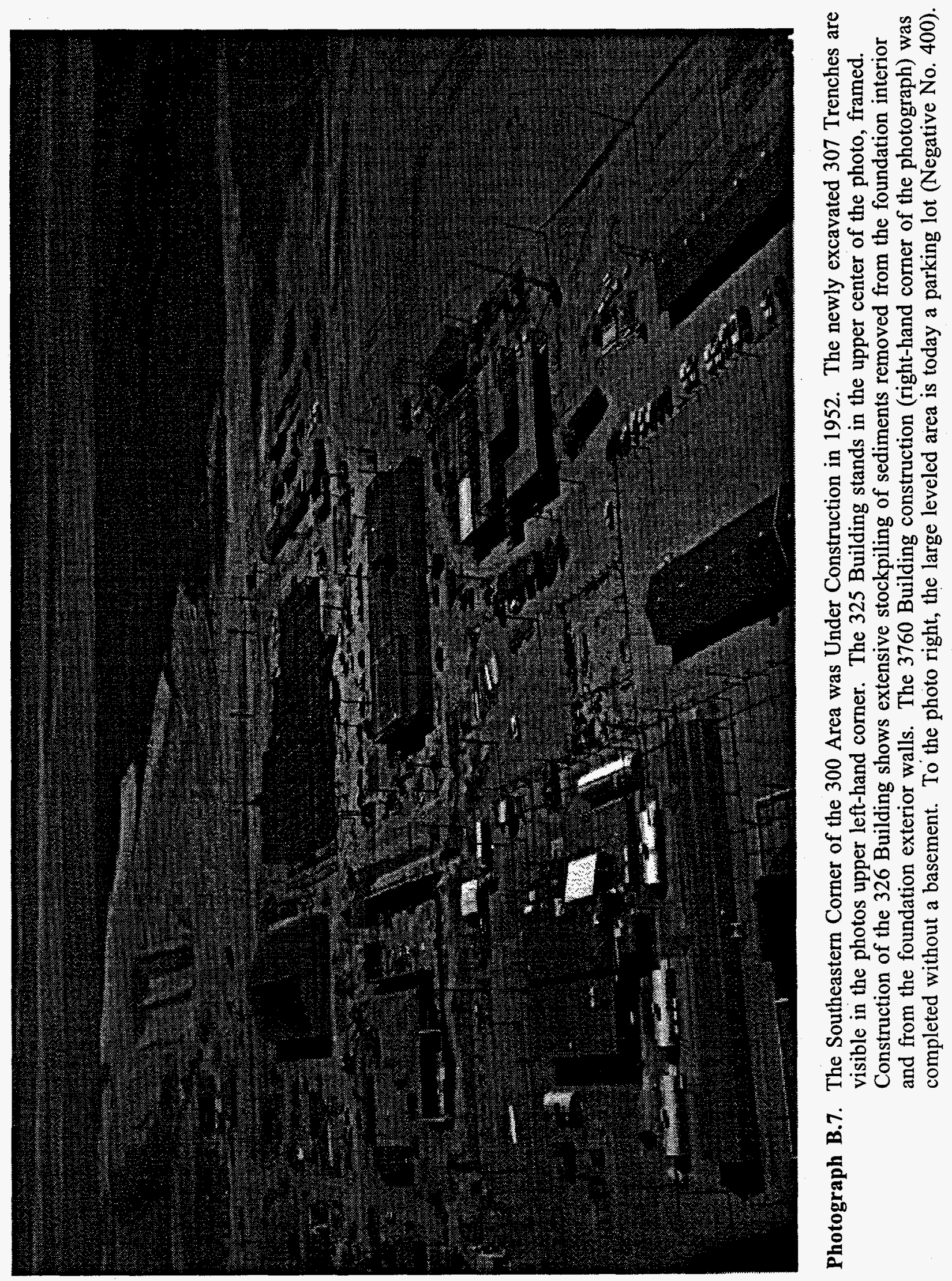

B. 7 

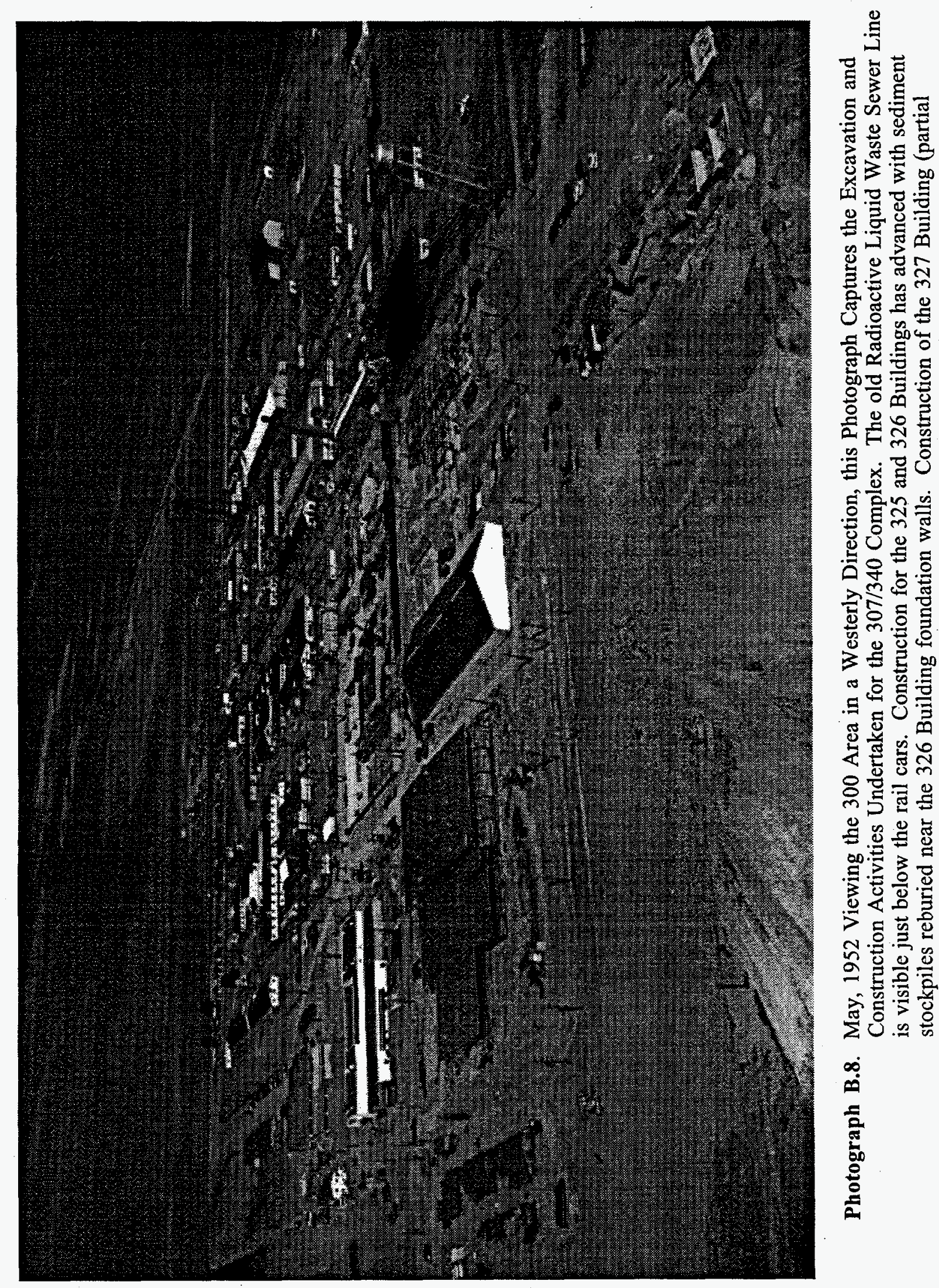

둘. 전 행등 을 응 壬司苫

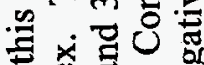
\pm 远

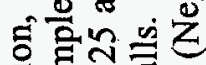
응 갱 记

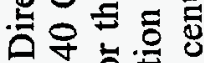
लि 휴 충동 능 을 3 올 ๙ 후응 .$\leftrightarrows \stackrel{0}{0}$ 8 可吉 这 헝 品焉兘。 邑氖芯 o. $\exists .2 \overline{0}$ 总它氞 $>$ 空焉. N응 次矛윰

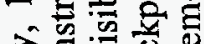

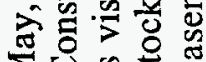
之造总

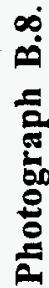




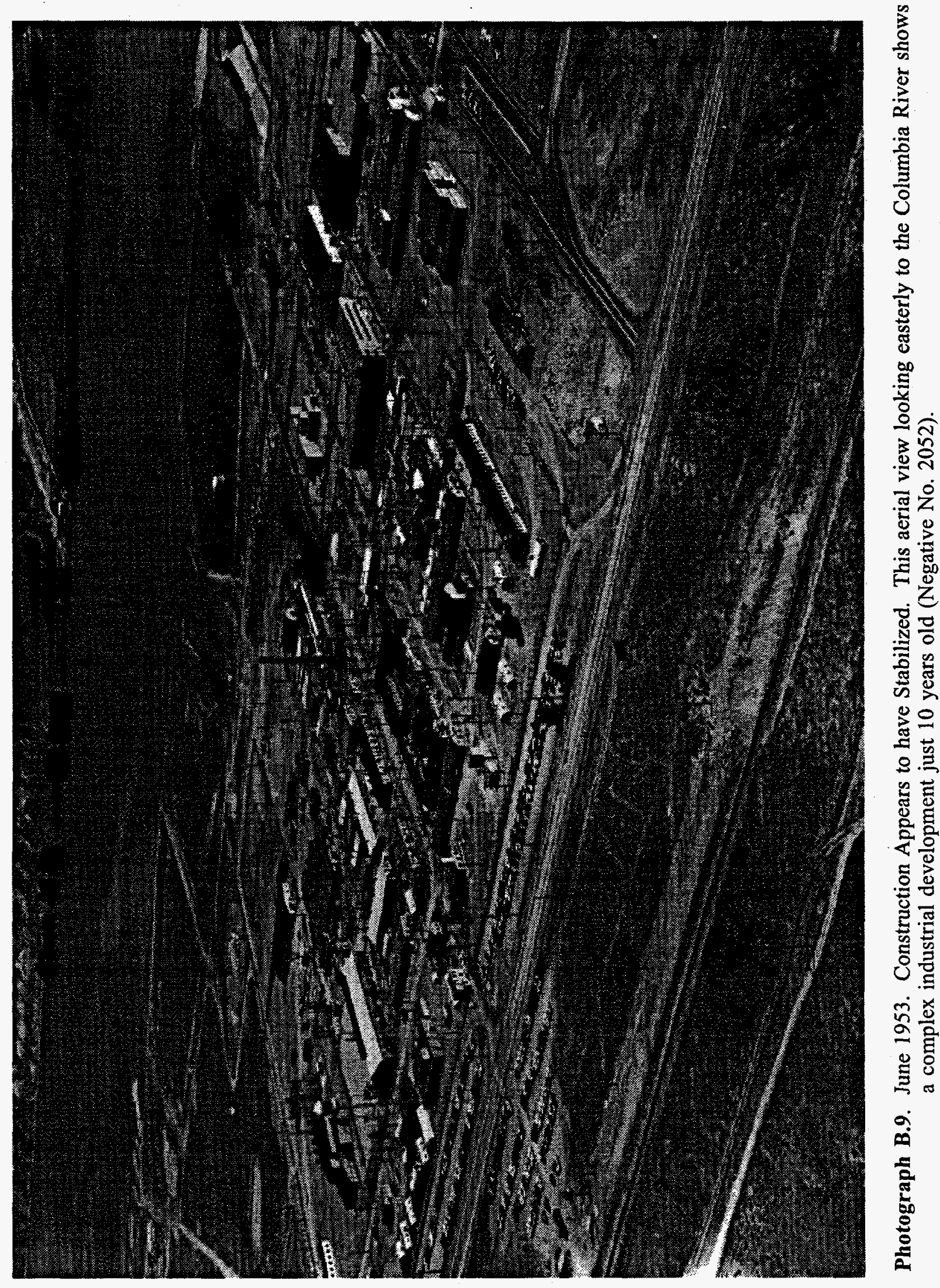

B. 9 


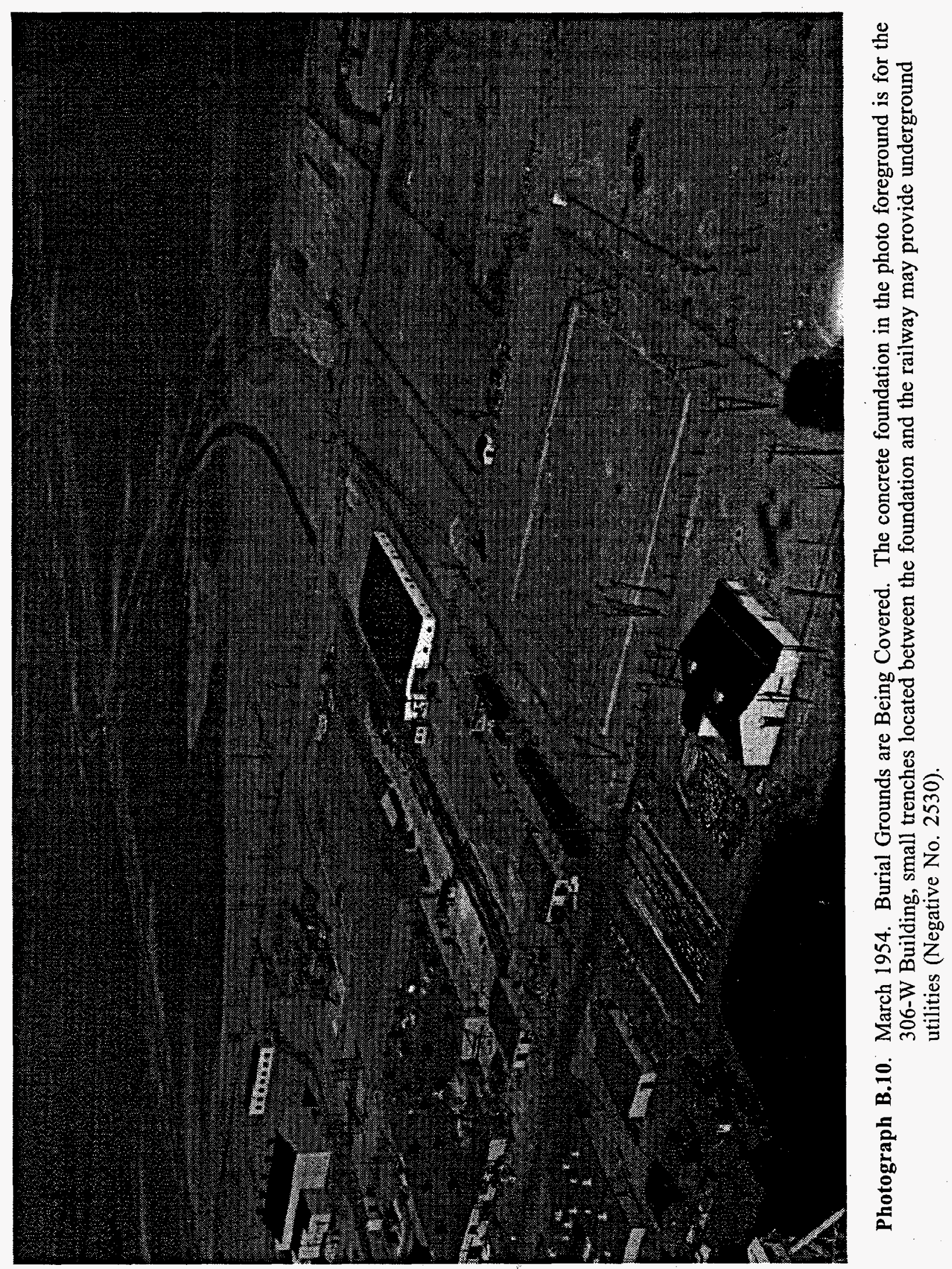

B. 10 


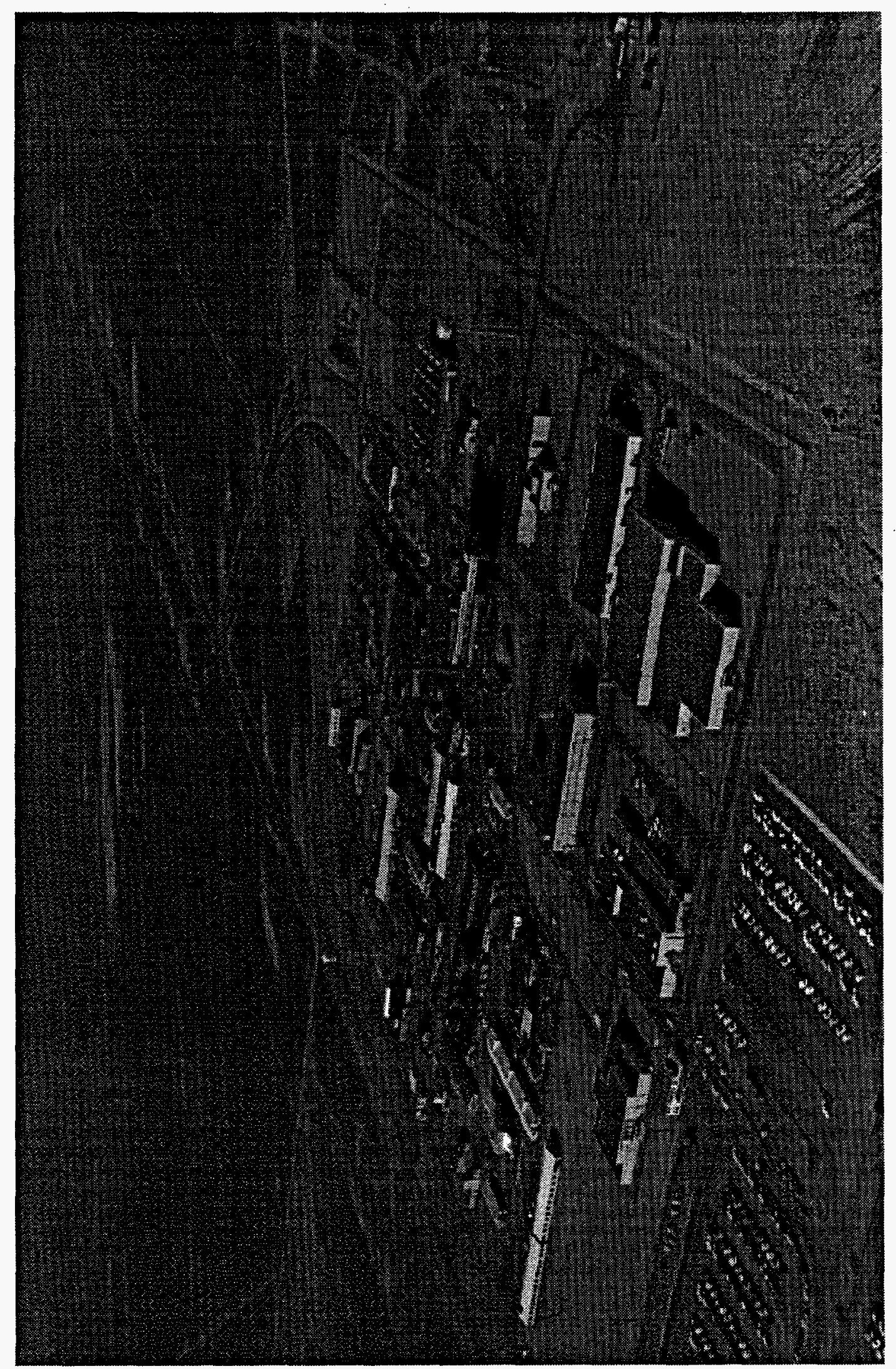

롱류

ผิ

กิ๊

을

कै

형

호용

.

로을

है

0 咩

을

용

खึ क

定

8 년

它出。

긍 응

글

응를

중

艛

퐁

ड

3.00

क田

边

흥

คั

융코

tho

월

술

.

U己

.

棺寻

을ㅇㅎㅇ

=

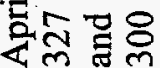

فำ

B. 11 


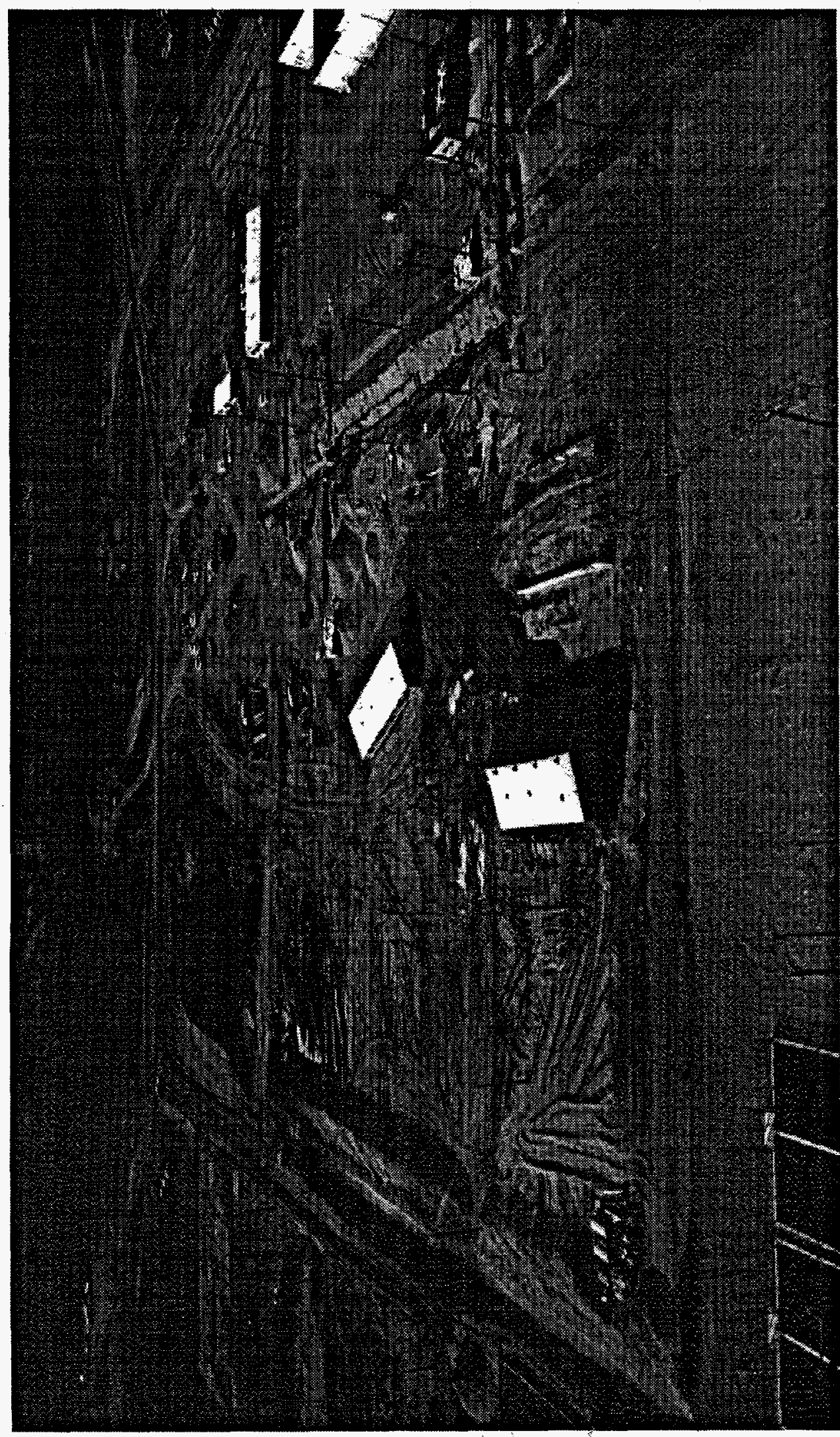

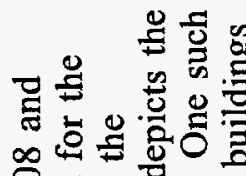

宑里

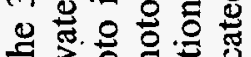

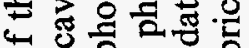

이요

형

瓶出的

政

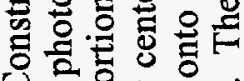

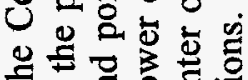

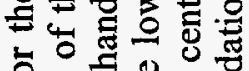

훈돈웡

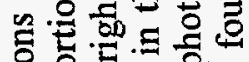

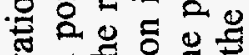

모의

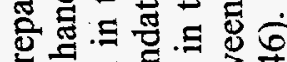

년

$=$ 응 영

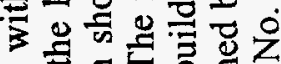

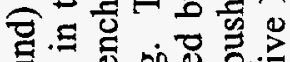

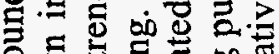

울. 웅을을 皆

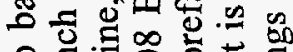

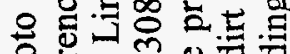
형월을

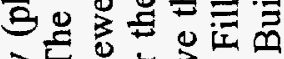
군 क्ष

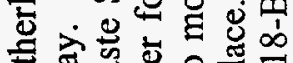
管

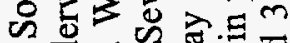

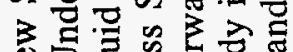

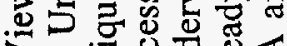

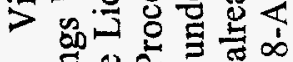

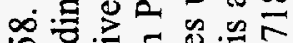
次흥

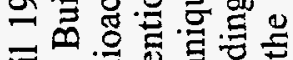

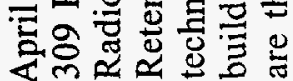

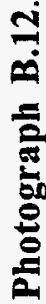




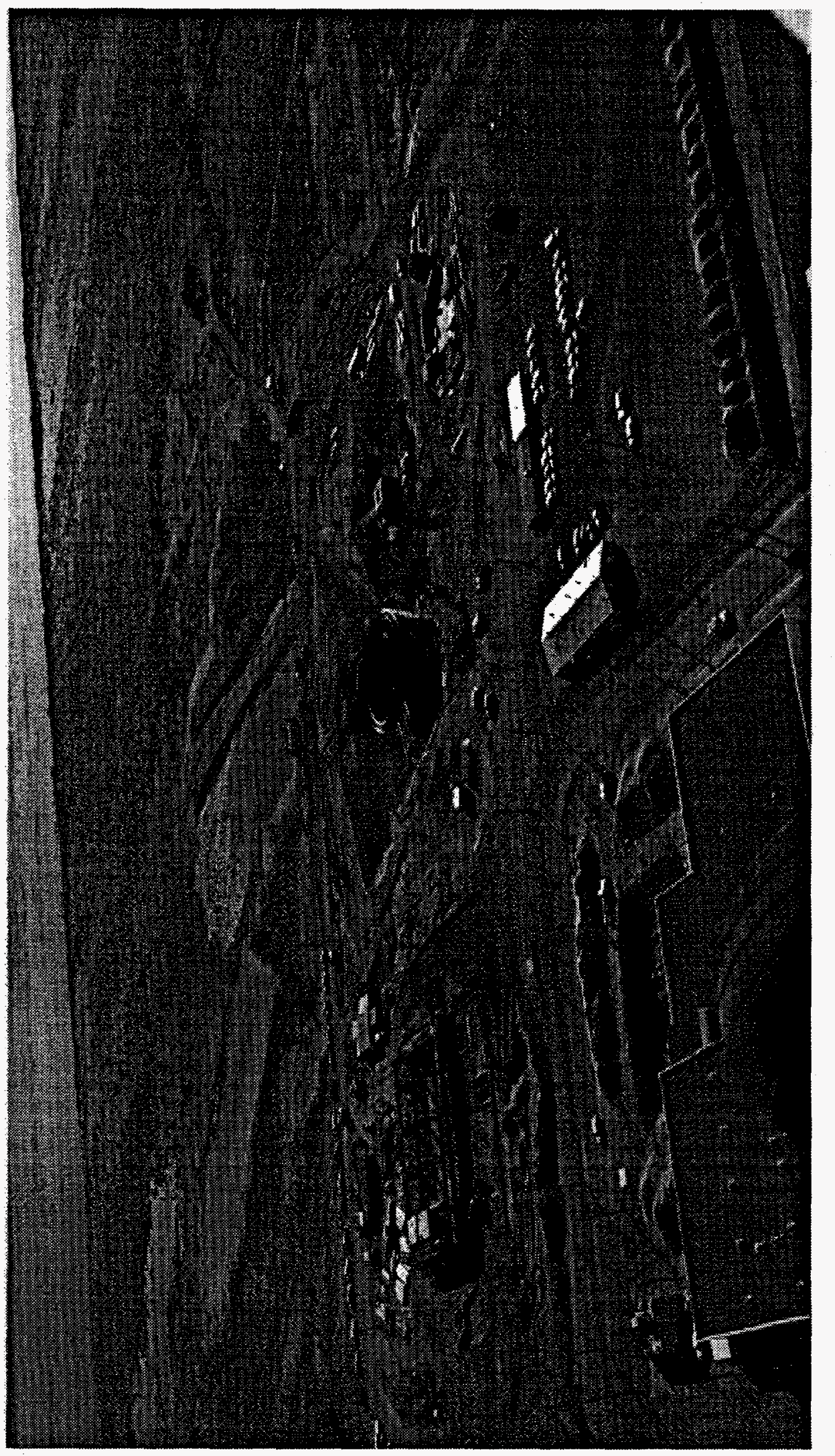

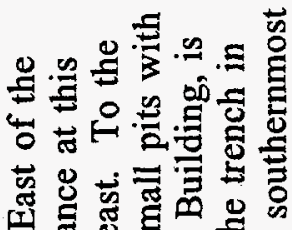
可 글을

娄

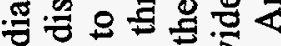

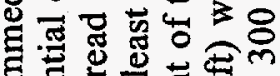

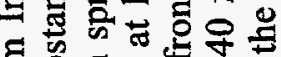

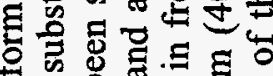
o

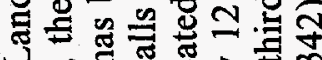

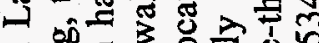

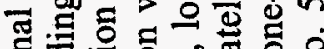
흠을

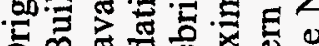

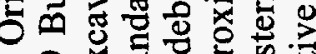
옹 可 :

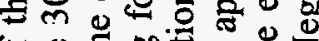
幽导 结声

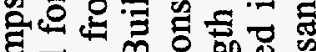
四 ○品 ๙ m心

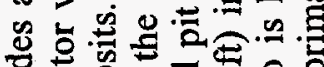
西

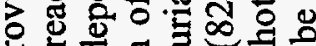

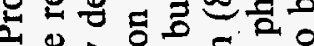
엉워용

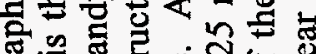
내응

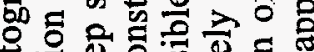

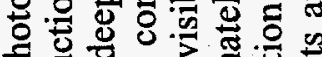

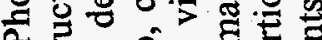
A n $_{0} 0$. .

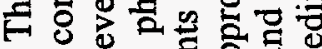

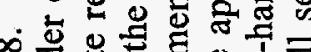

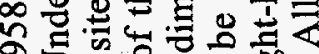
م与 की

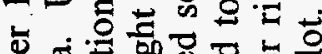

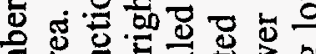

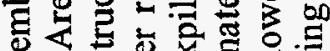
क ज्ञ

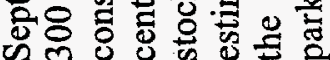

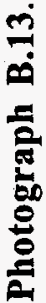




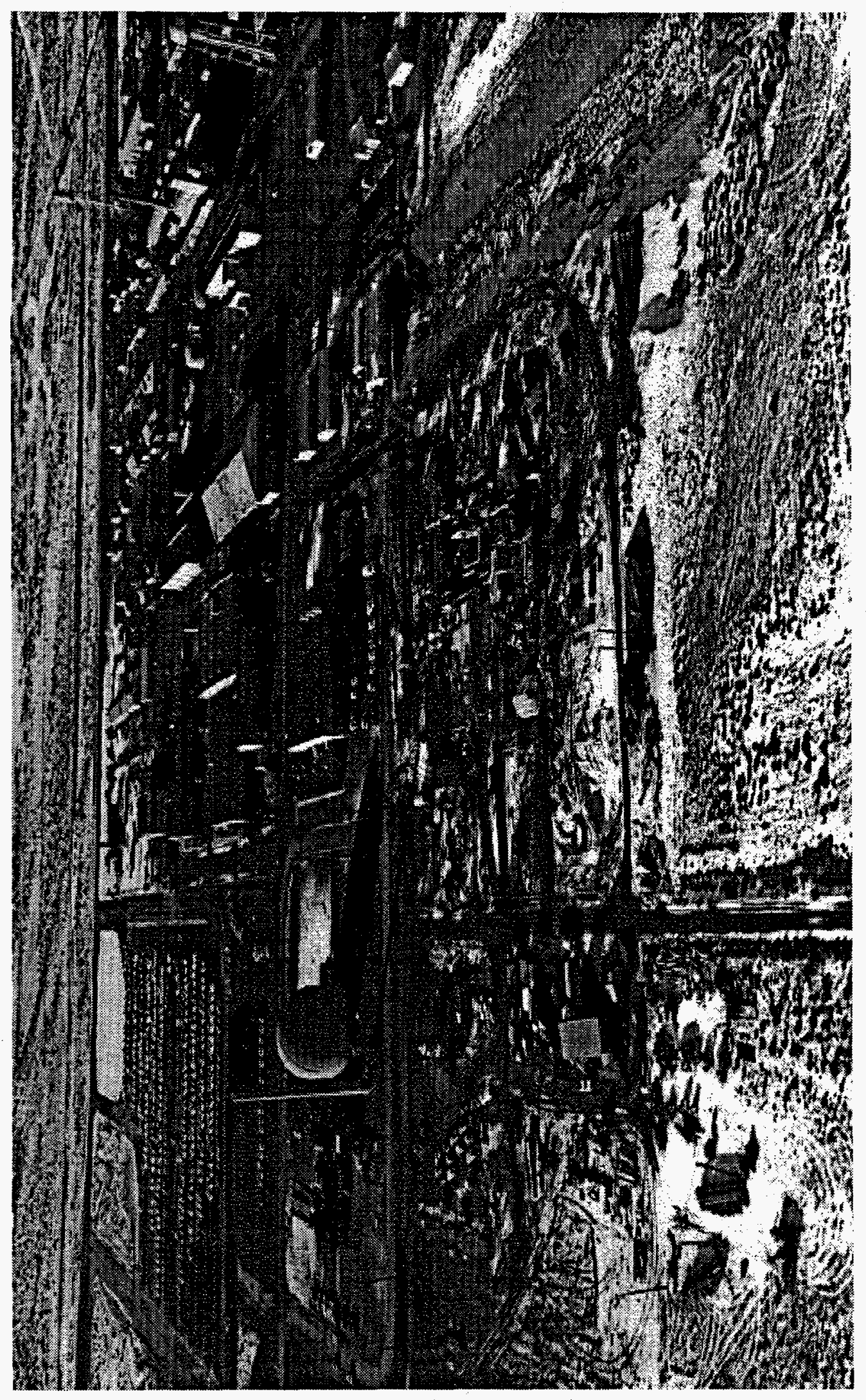

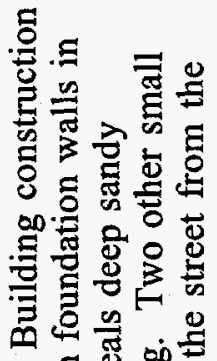

oิ:

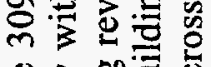

在品票

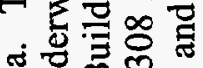

嗐

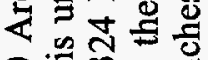

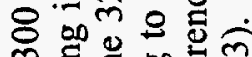

m $\cong 0$ 足

흘 능응

을

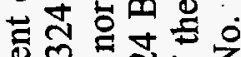

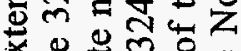

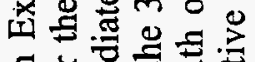

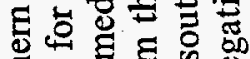

吅罗

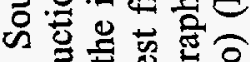

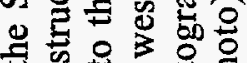

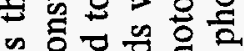

过定 可

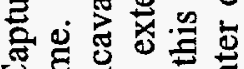

U.

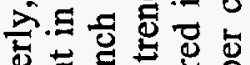

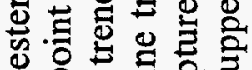

年

= n

है स《ठ त

更

证

$>$ 굴 웅

. 5 웡

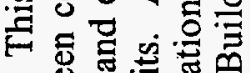

的诺

ชำ 웜

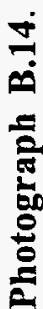




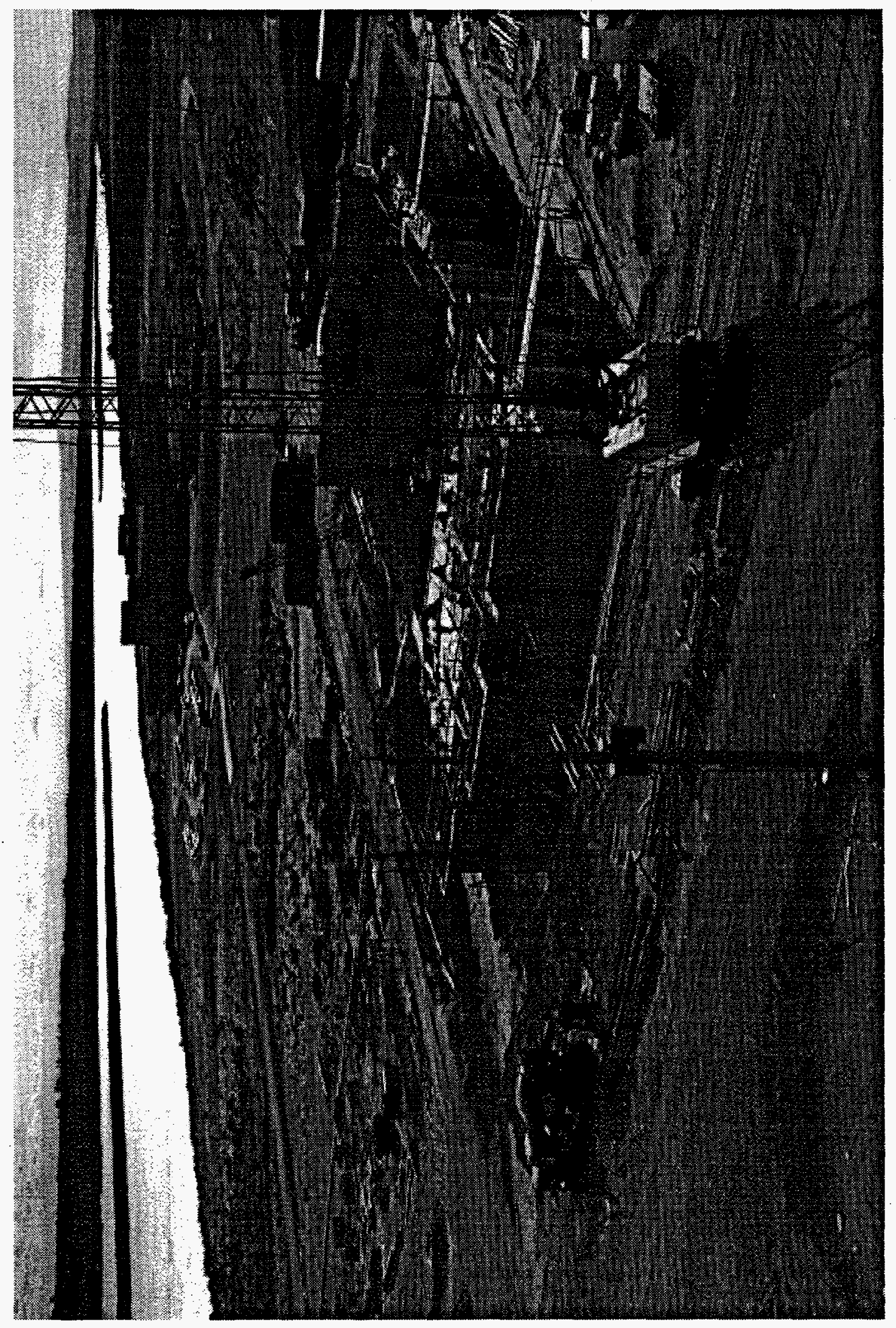

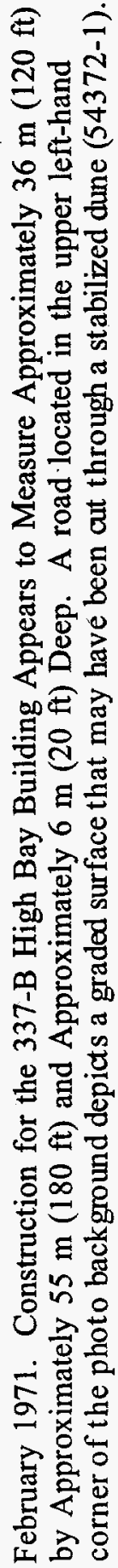

$\frac{10}{0}$

물 


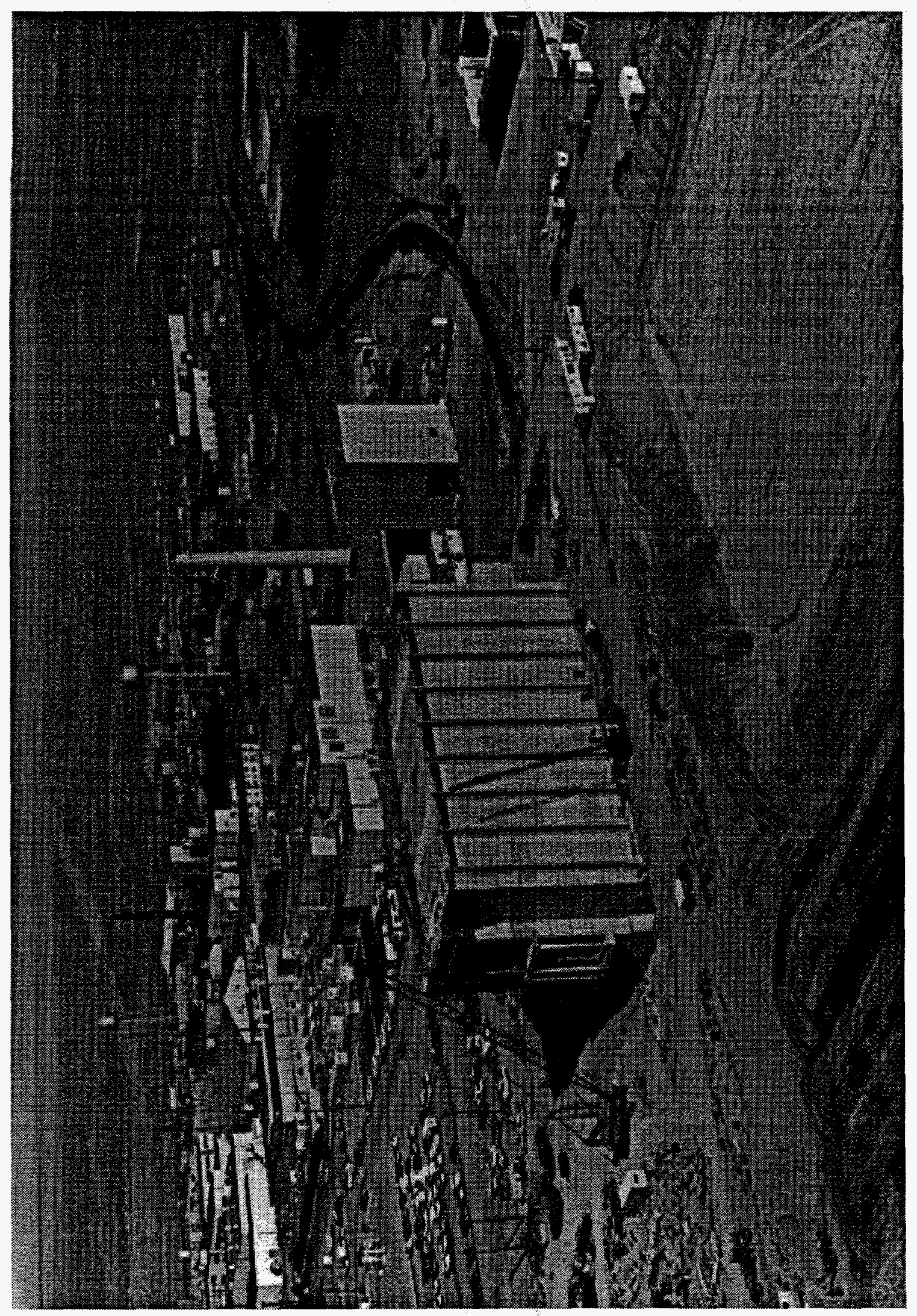

을

$=$

$\stackrel{\circ}{\circ}$

홍

동ㅇ

응

웅

口

号

.

.

8

己

ज० कo

:

品

0

忽

on

일

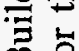

웅

तิ

올

氙

站

뎌융

过

ב

E

웅

옵

क

$\dot{5}$

ఏ을

구

Чํㅓㅇ

فำ 


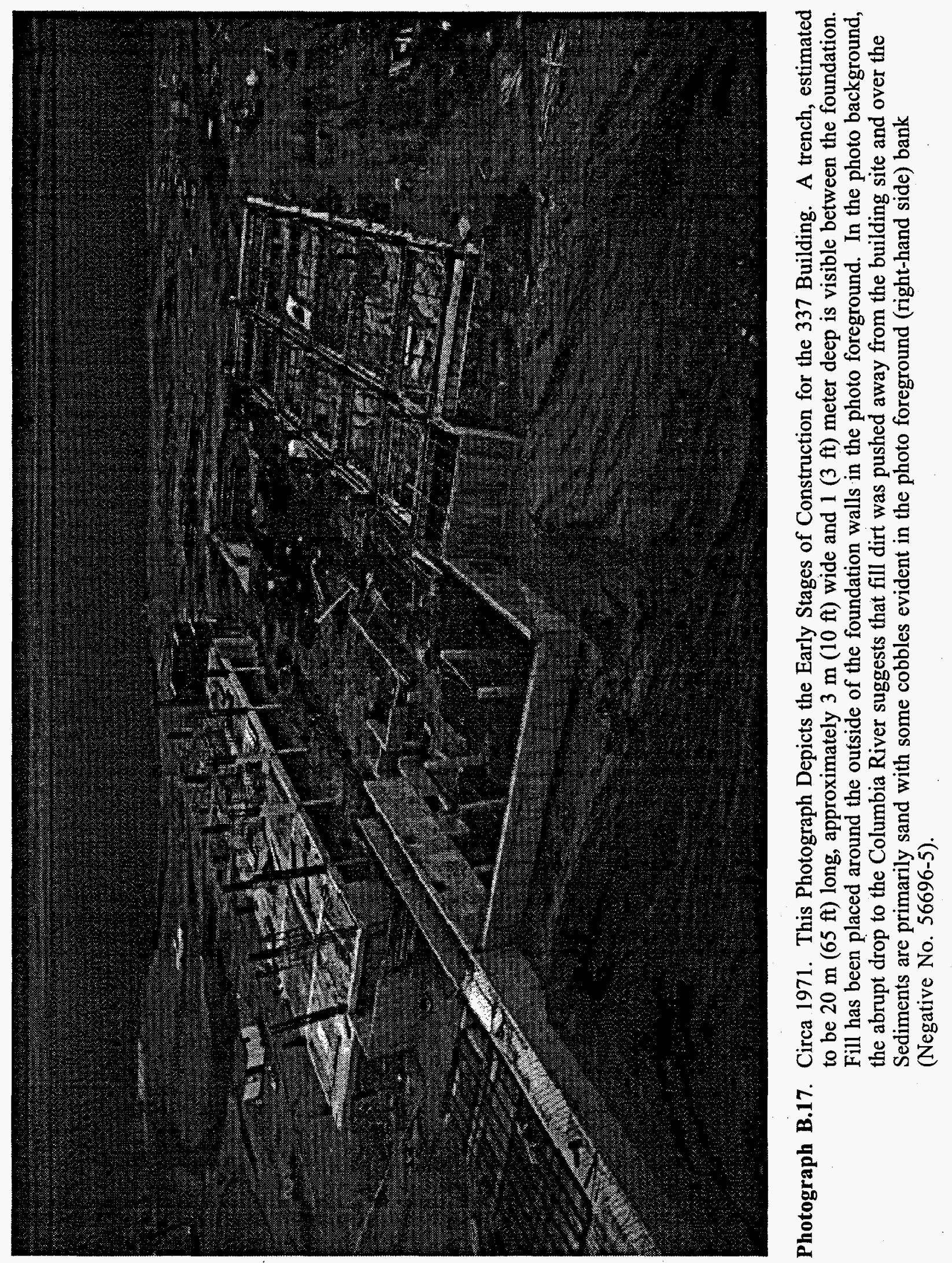




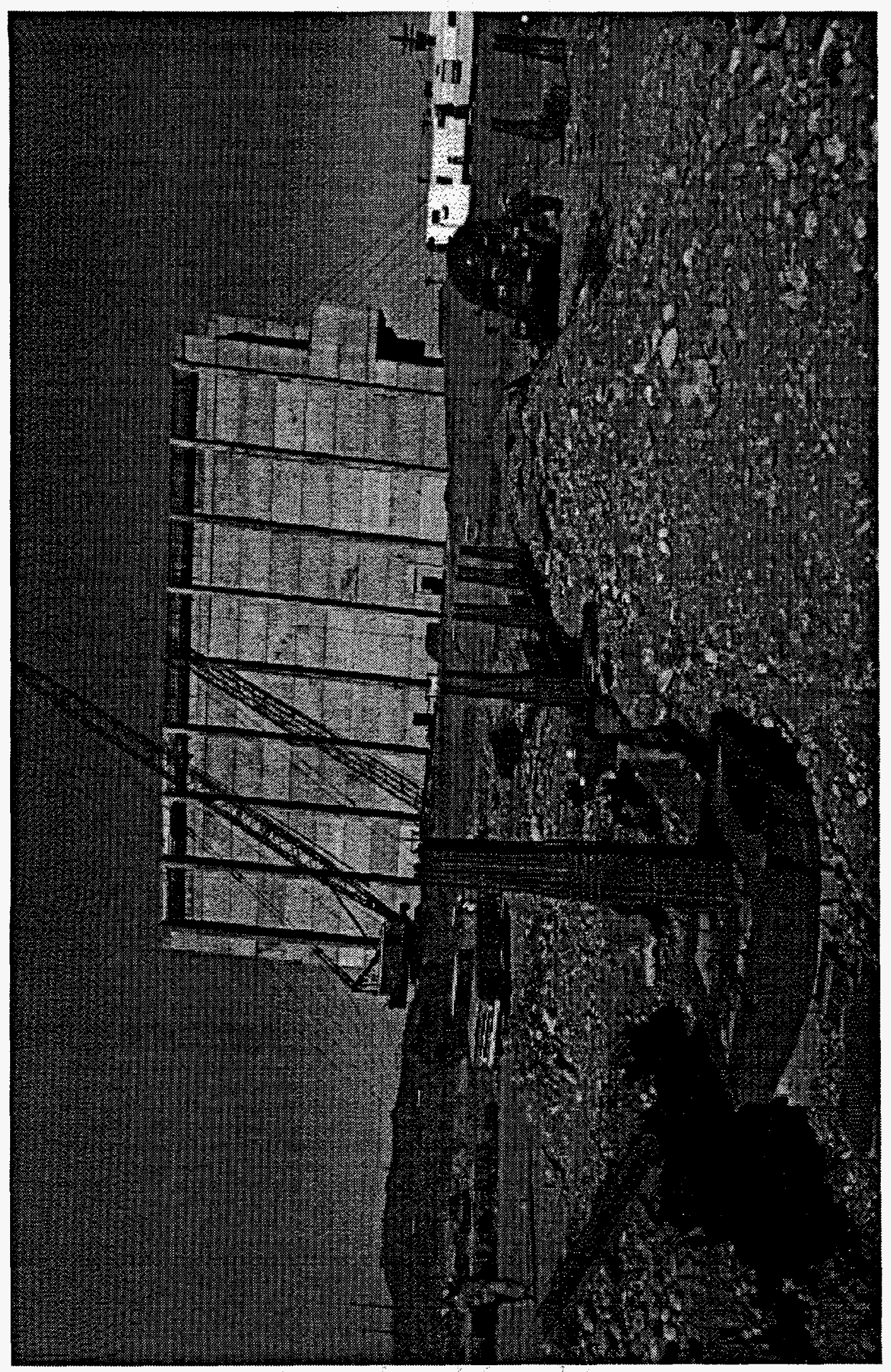

藏

5.

表

प⿺辶

ต 8

मै है

害哭

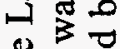

응 홍

记要

킹

今०

ड

สี

융

5

คํํํㄴ

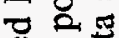

冚焉

ठㄴ

然定

3.8

on 20

害苛

然政

网 氜

กิ

m 0

옹.

밍

焉

国吉

용

至要官

电 o 员

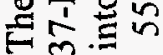

$\therefore$ 㝬

즈을

으면월

点

50

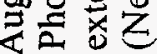

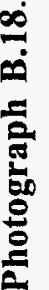




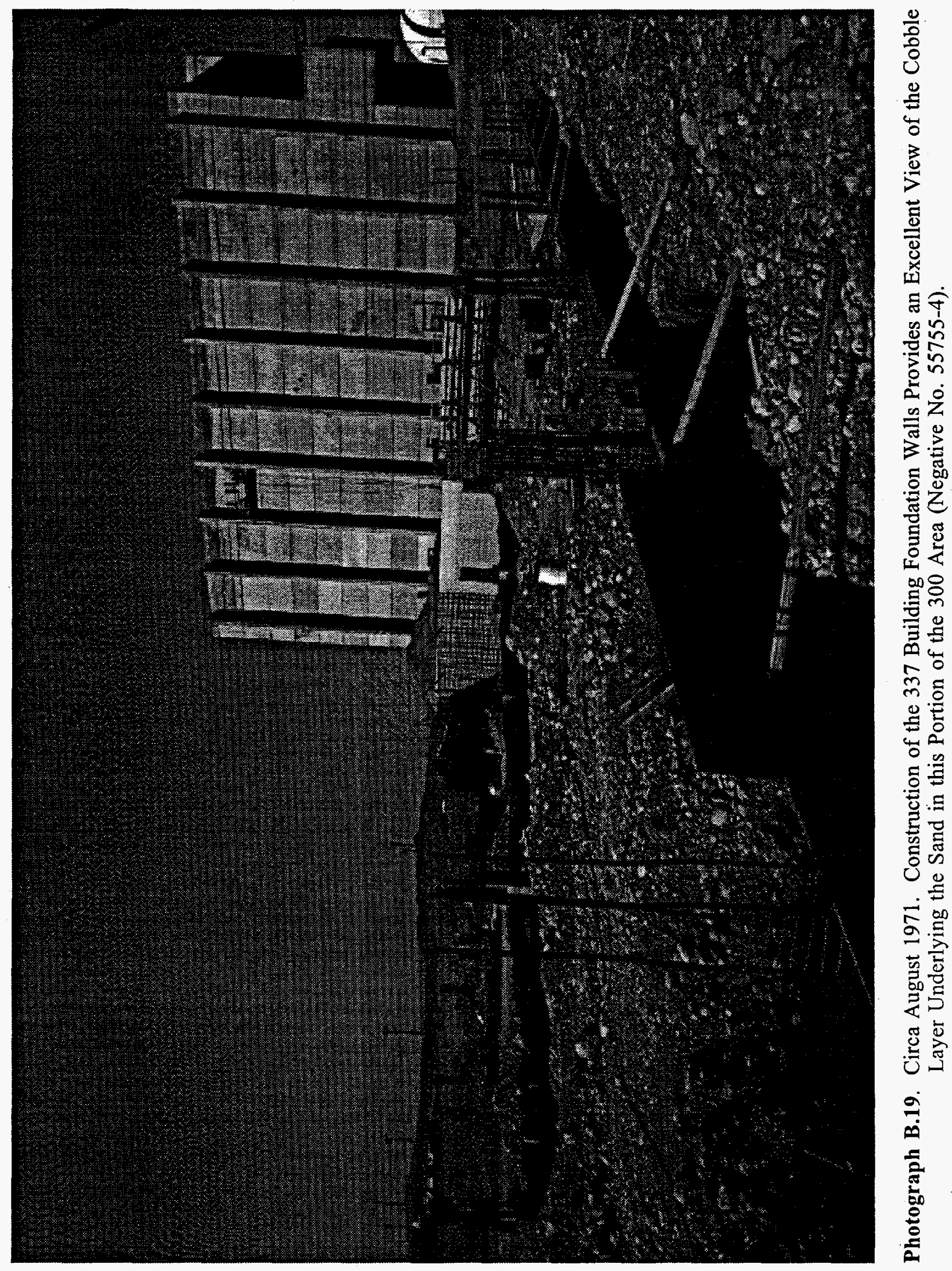




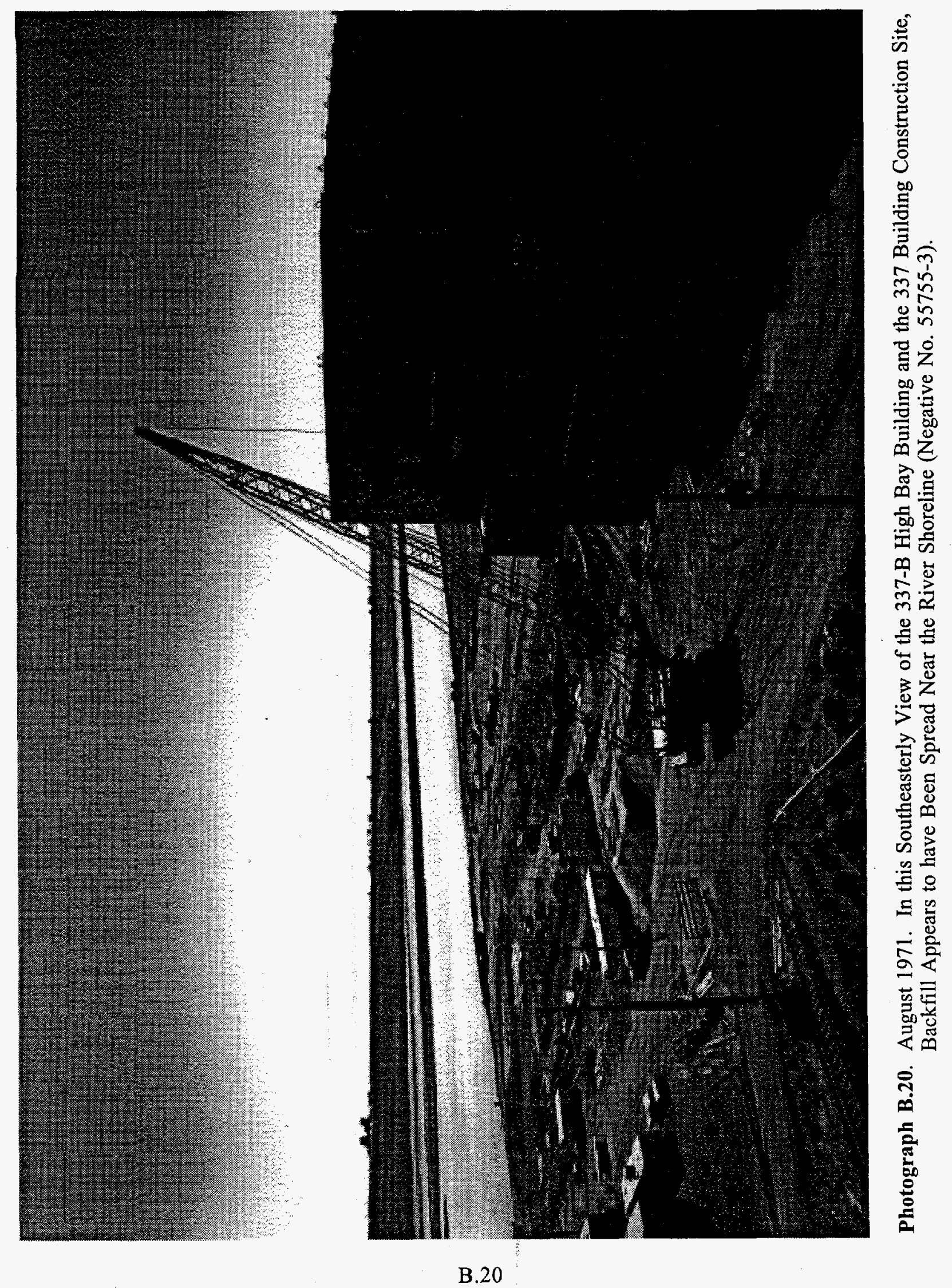




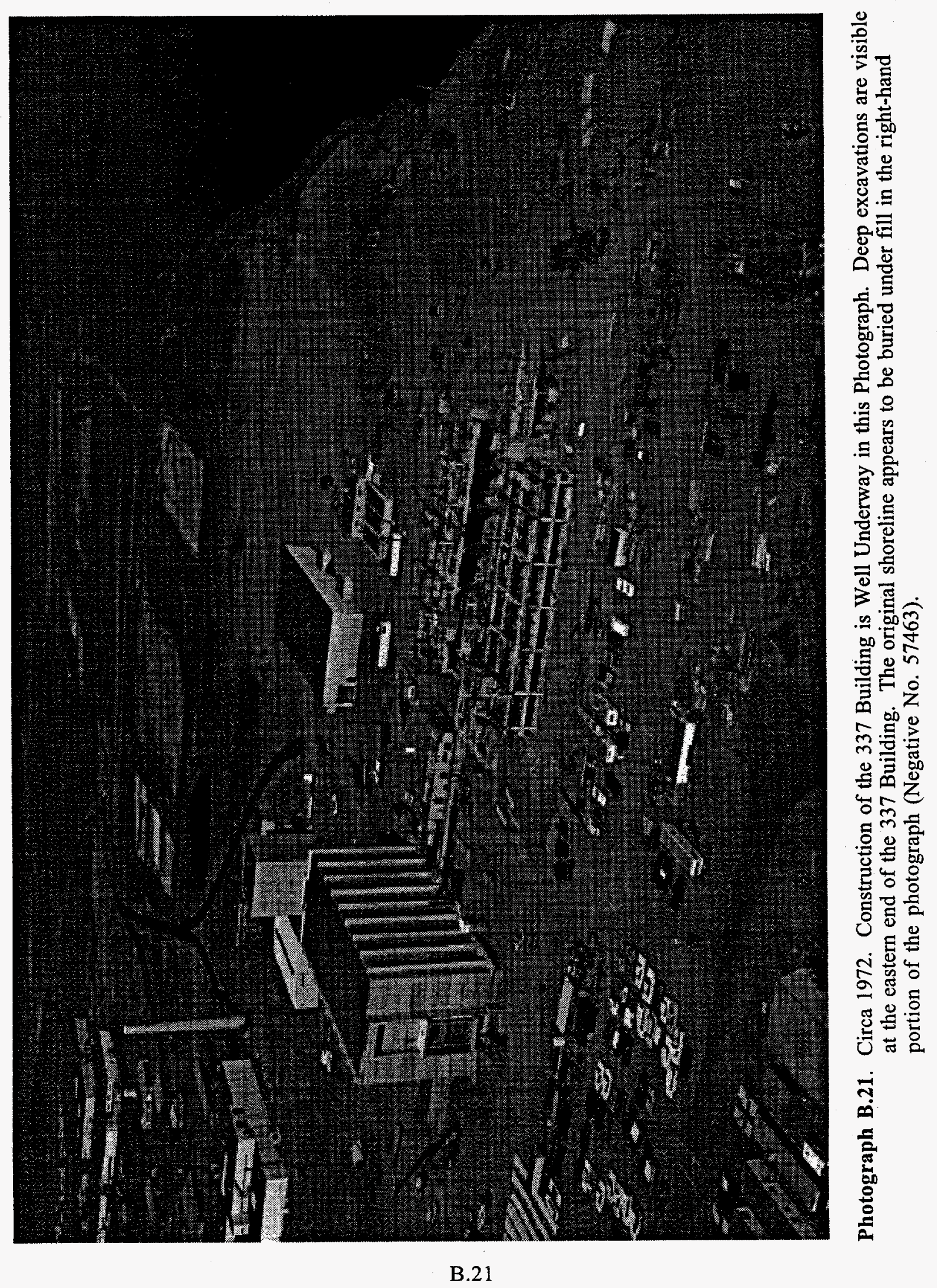




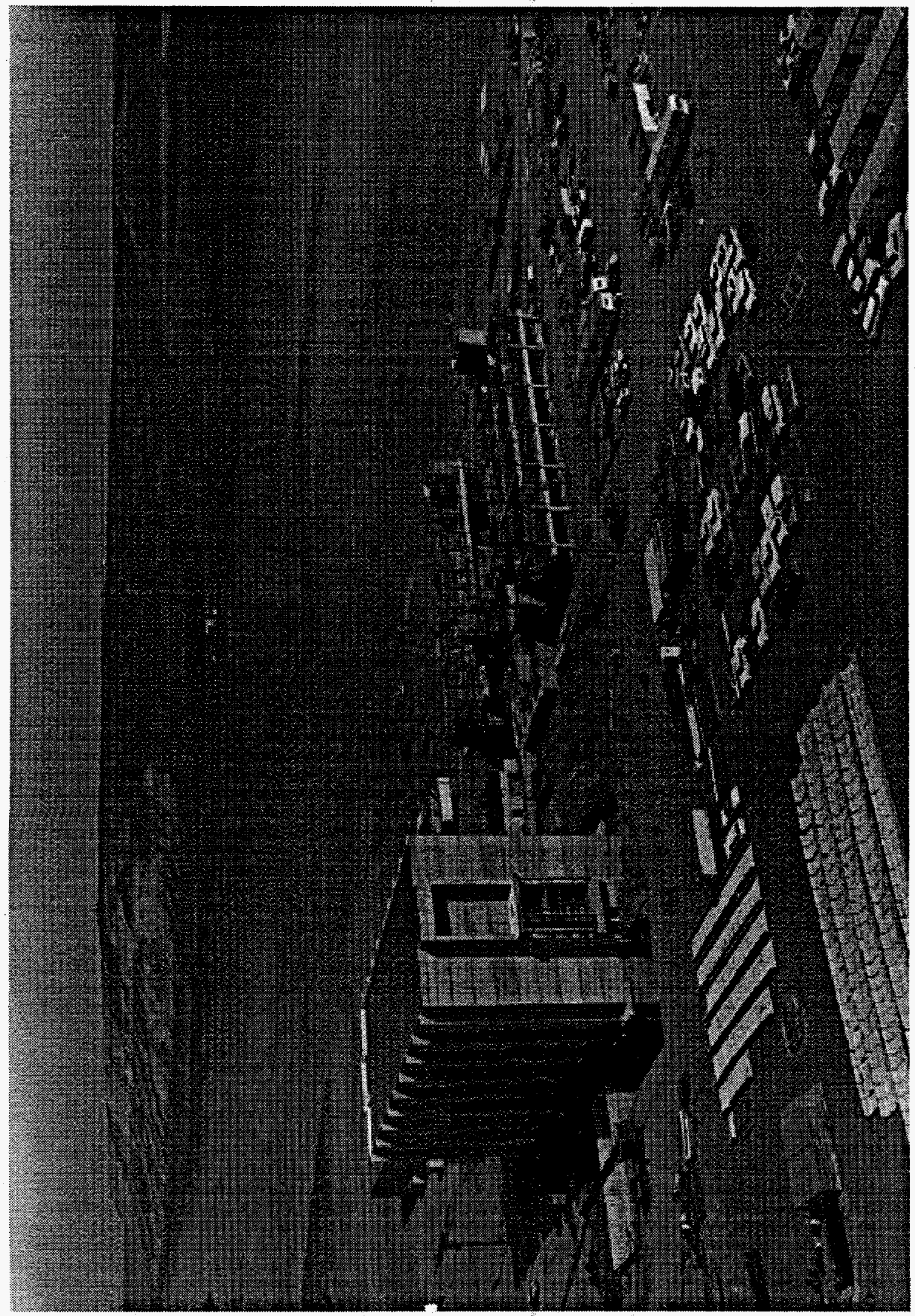

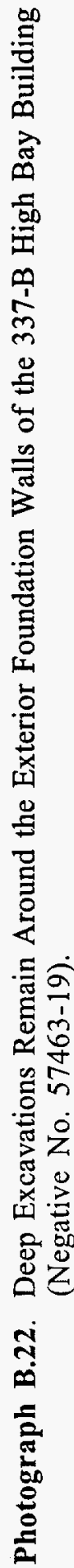




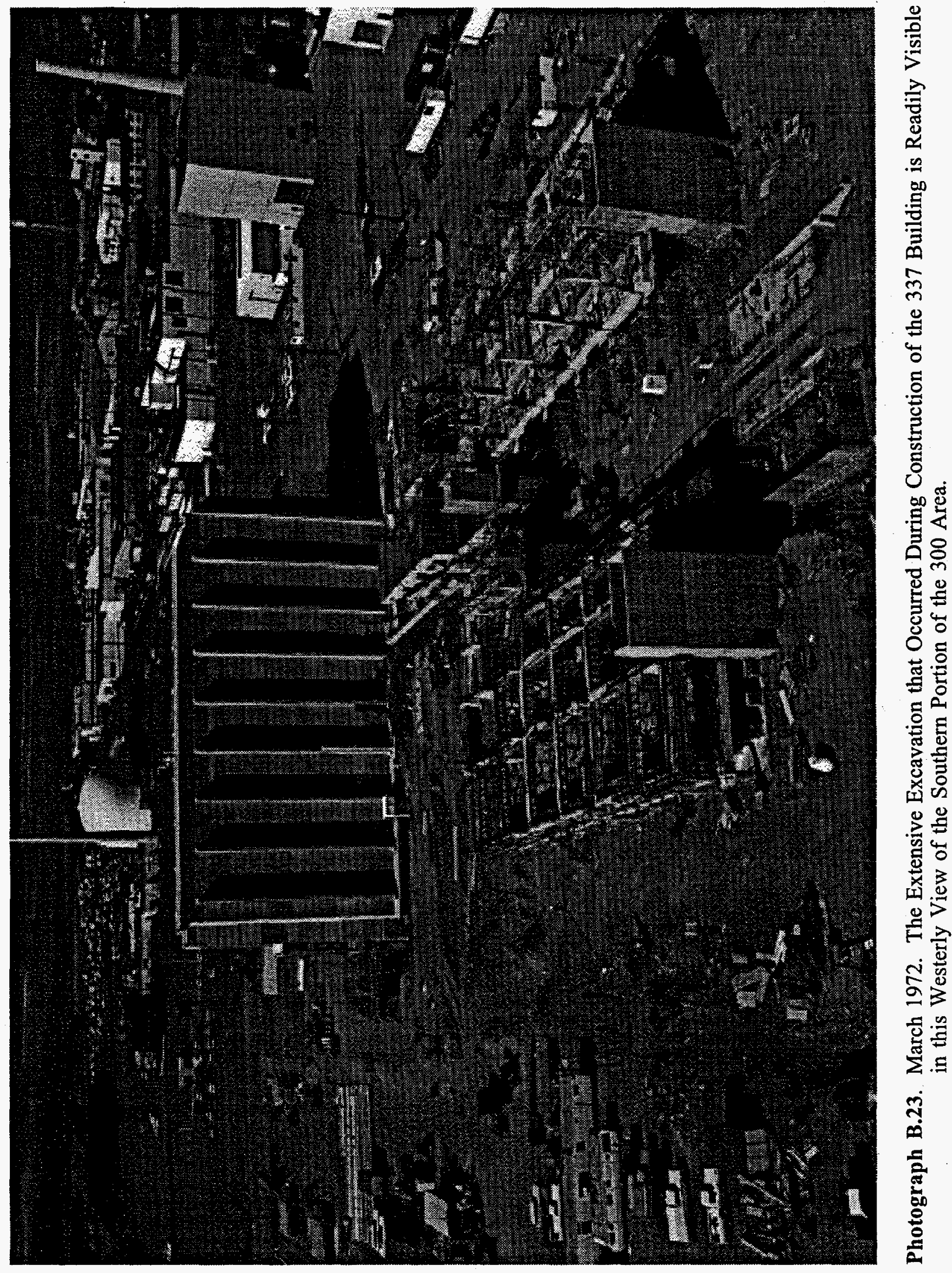

B. 23 


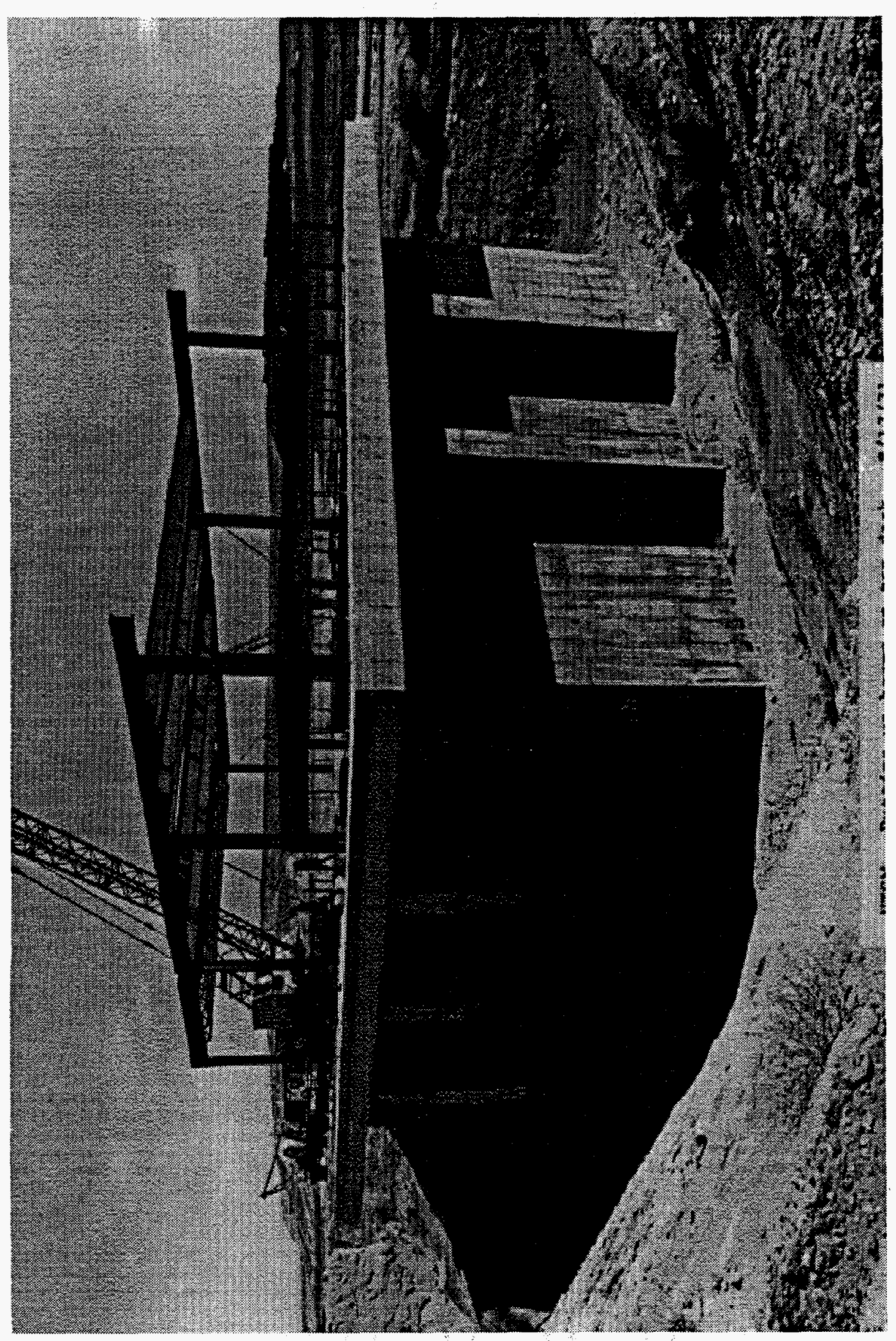

응

오

寻

흉

ह

ठ

항

픙 융

롤

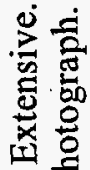

믐

38

ธิธ

可

$\dot{3}$

位

00 뭉

클

至

o.

出至

के

每导

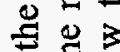

훈효웡

드응

栗资

궁

요

동

룡ㅇ

$\therefore$ 릉

20

动

홀 峁

《元

فำ 


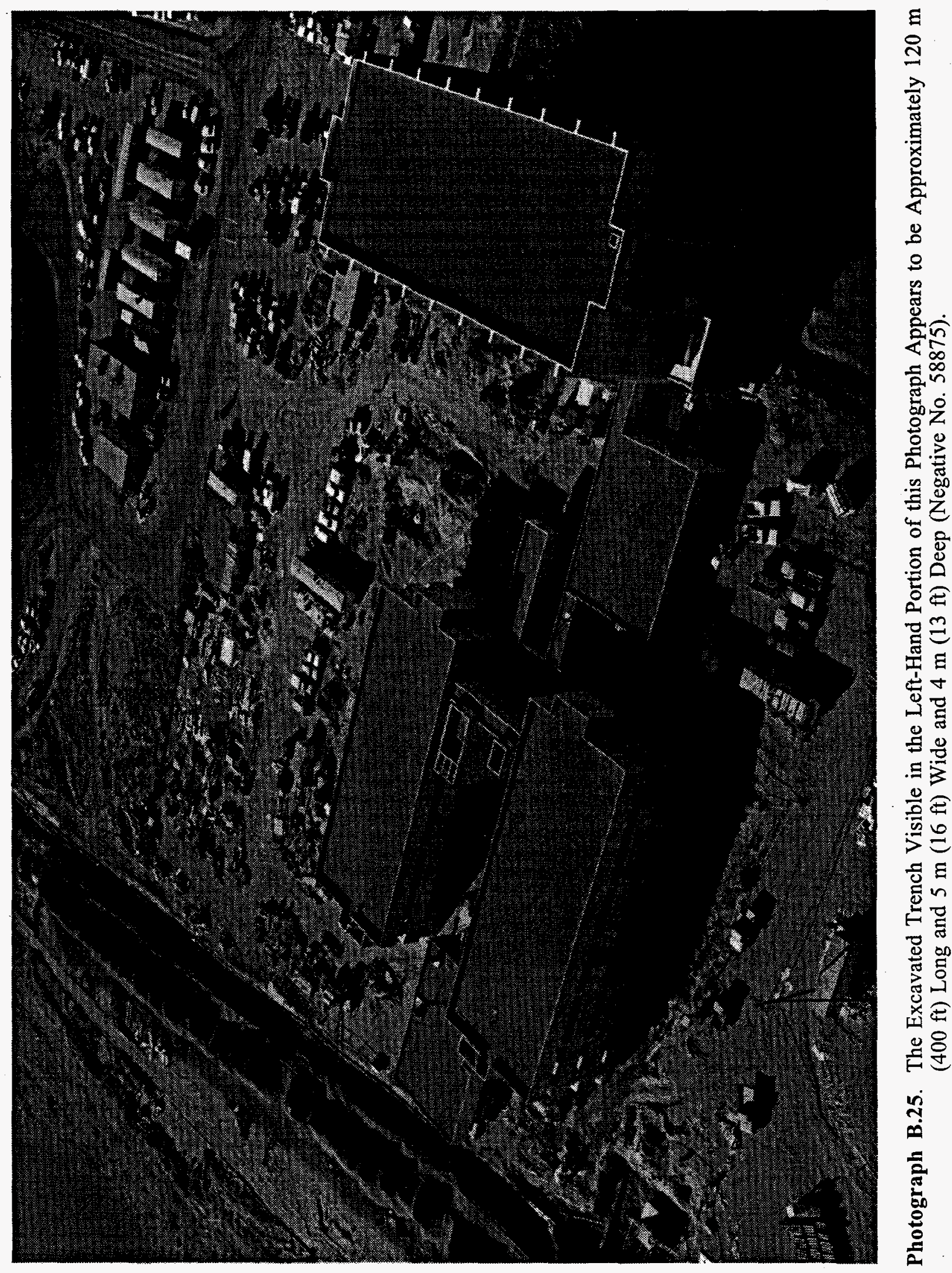

B. 25 


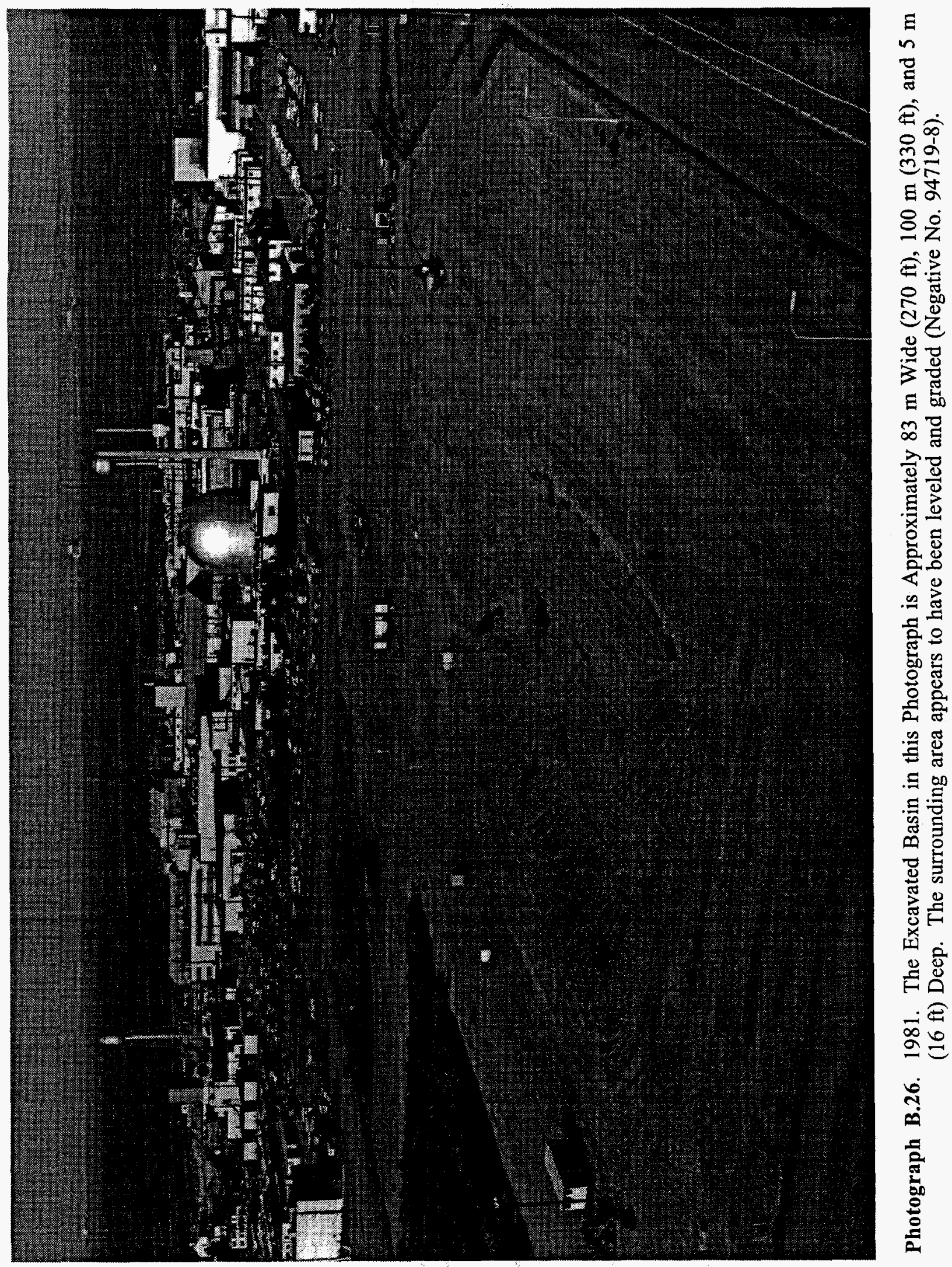




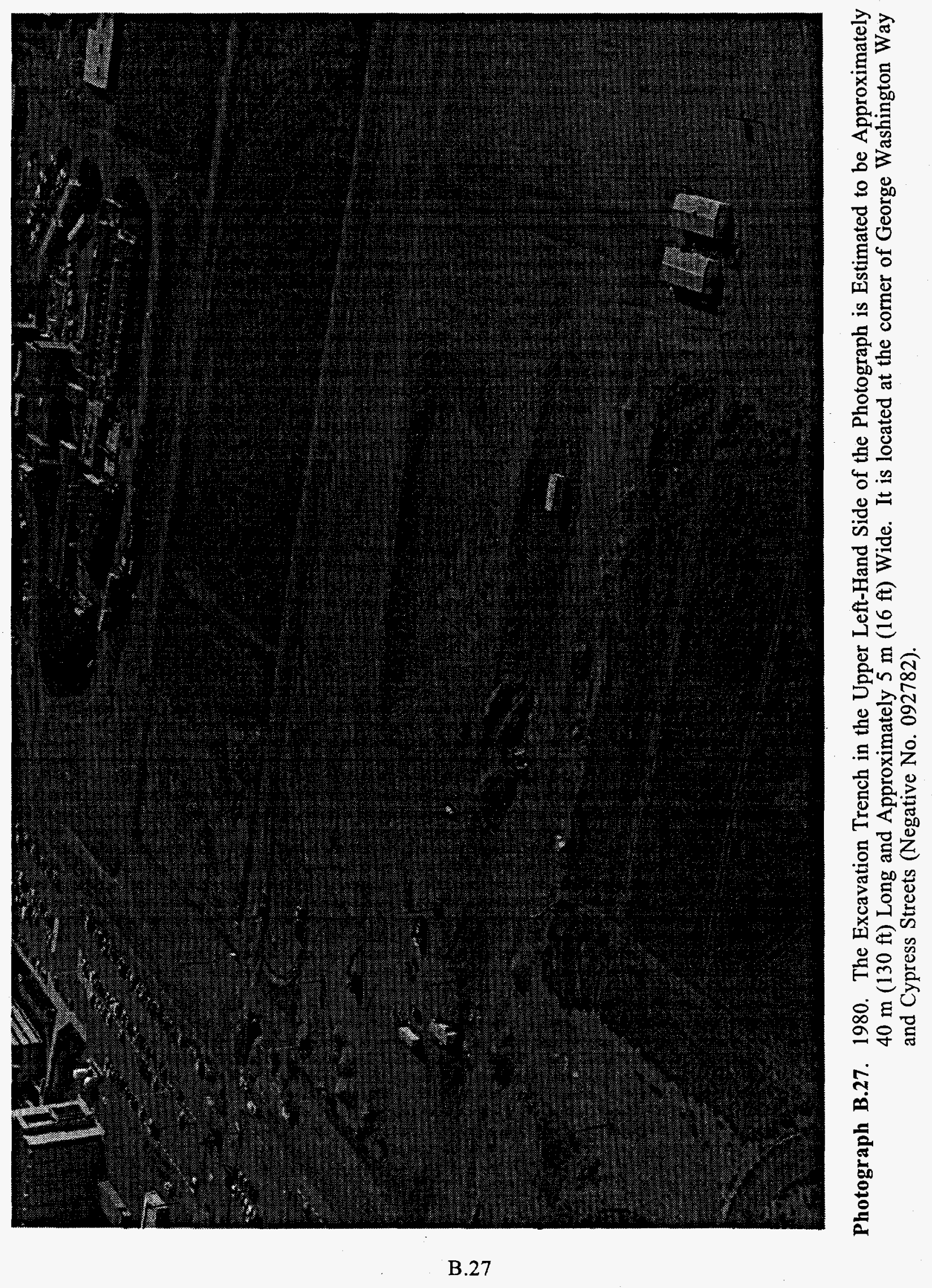




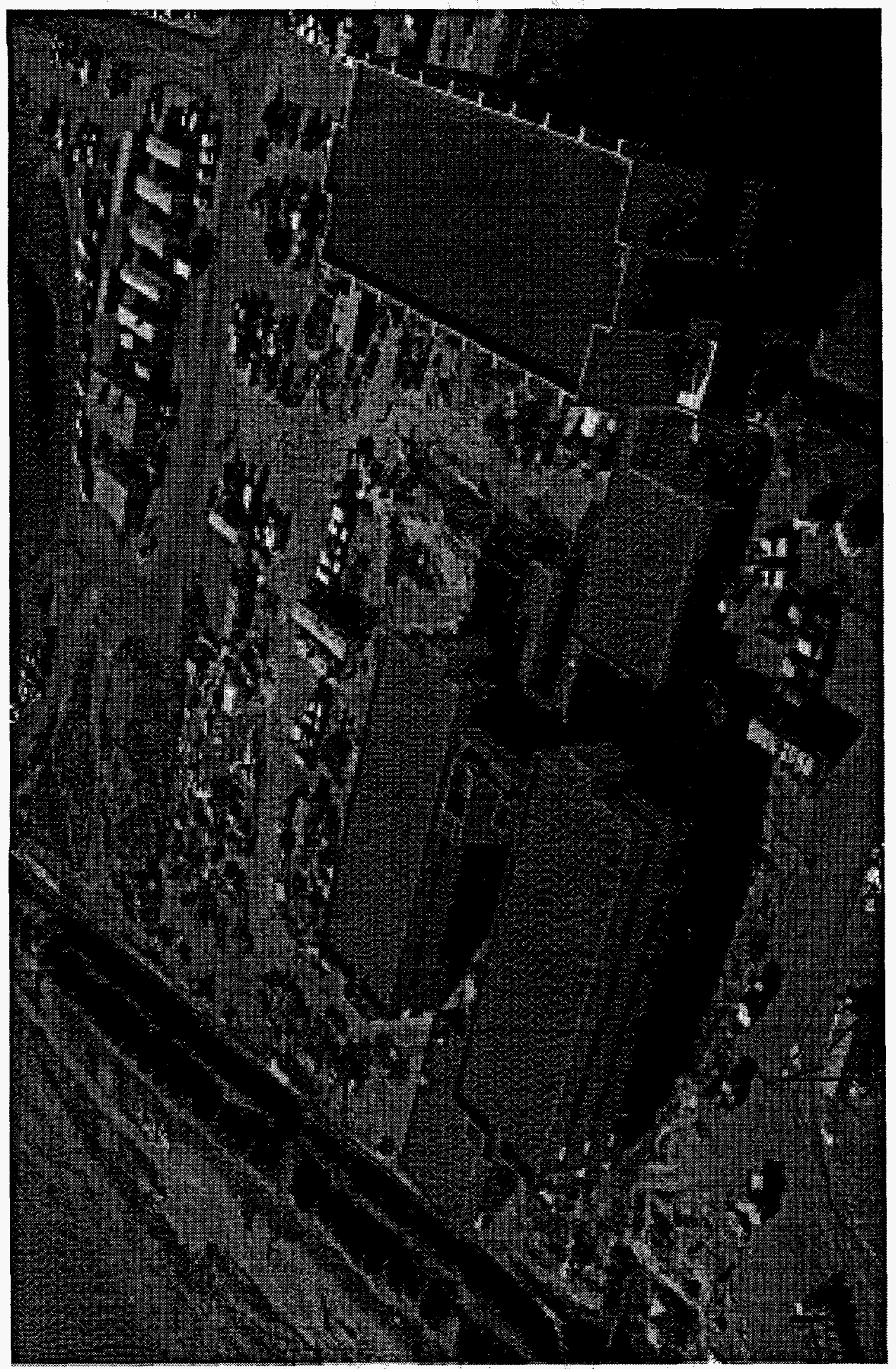

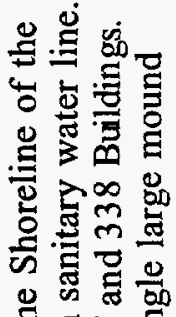

동

吅包

멍요

$<$.

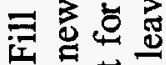

㝳尔 过这焉

월

흥

苞它

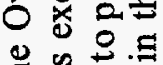

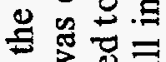

可

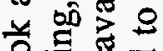

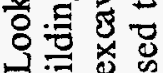

几

\& 3

믕요련

的起

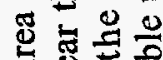

㝳艺至

유요

늉ㅎㅇ

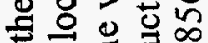

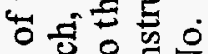

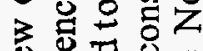
氙守 $>4$ 记 ]త 安 《. 을

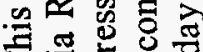

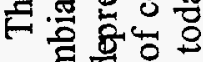

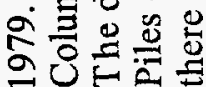

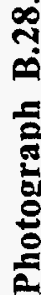




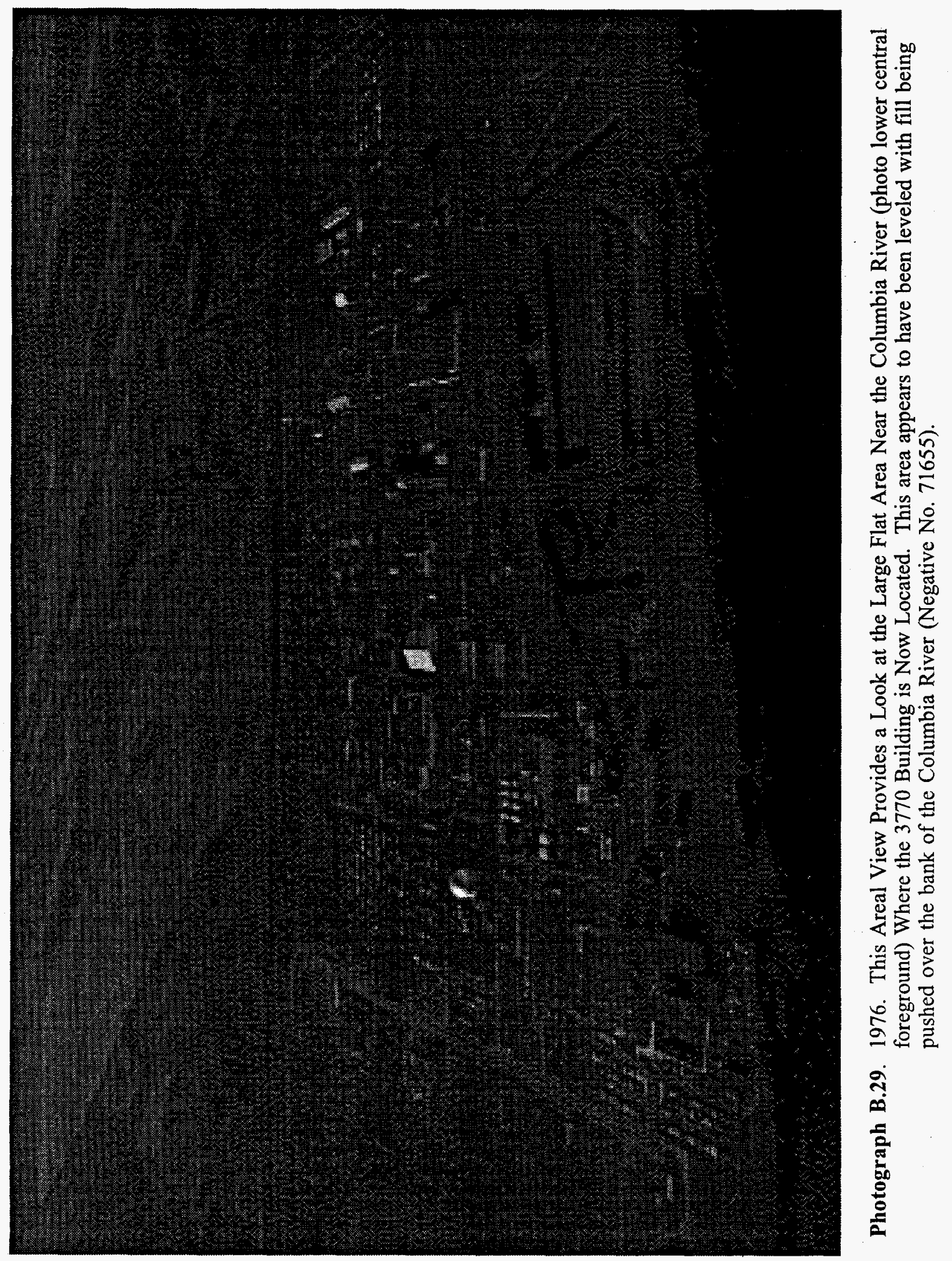



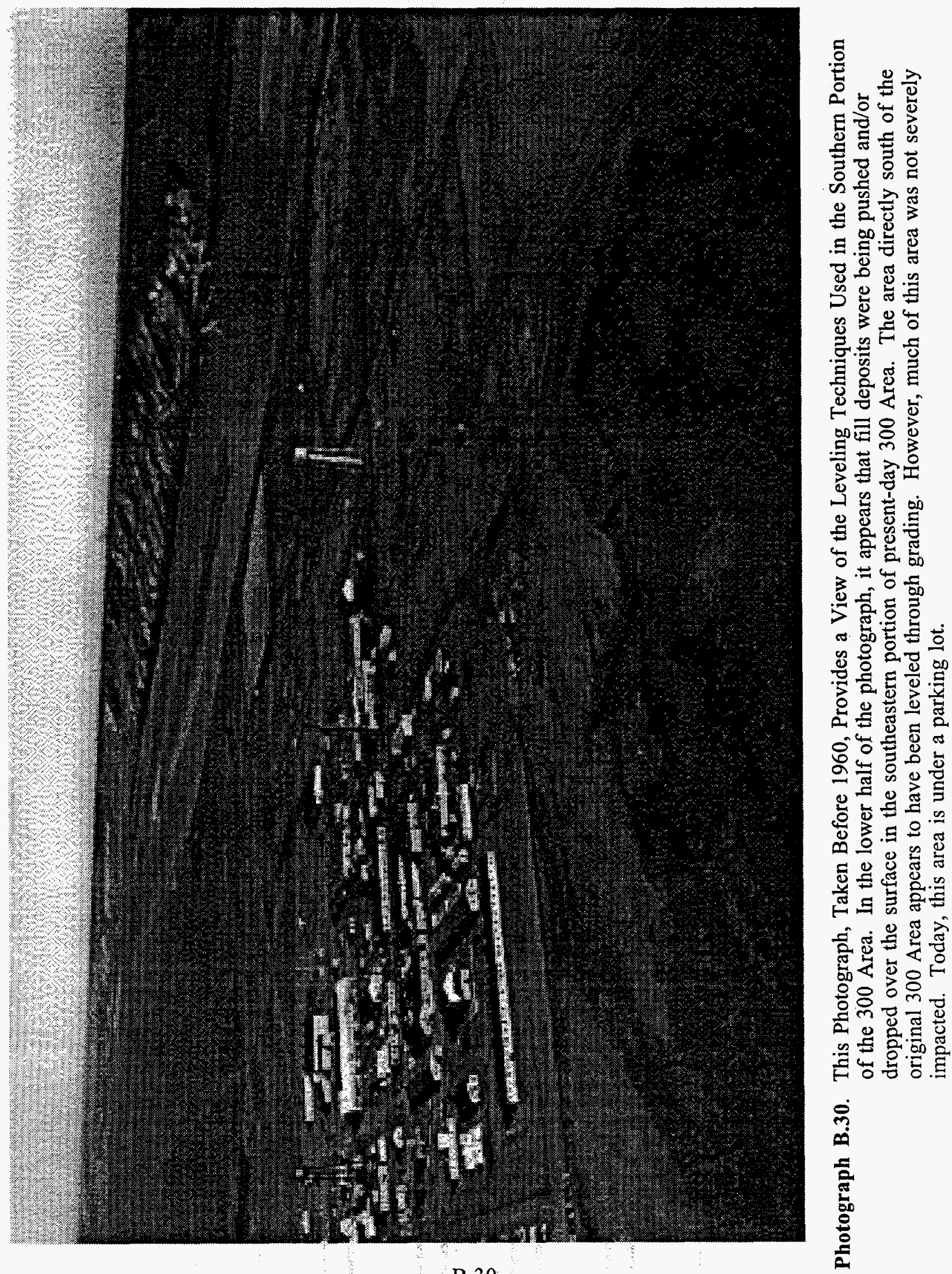

B. 30 


\section{Appendix C}

300 Area: Historic Maps 
Pasco, Wash. Quadrangle 1917 Reprinted 195115 Minute

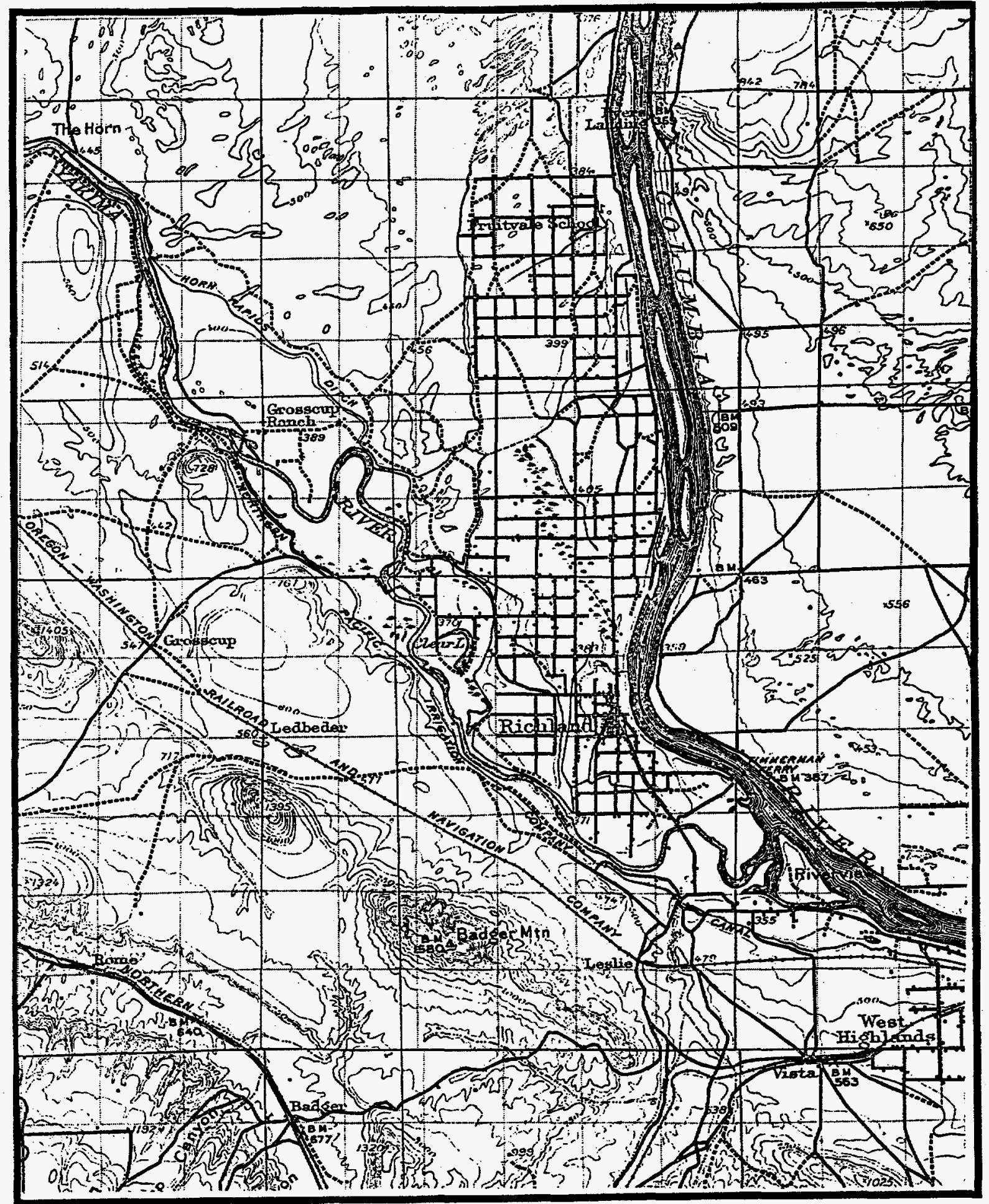

Figure C.1. Pre-Manhattan Project Landscape Where the Future 300 Area Would be Constructed

C. 1 
Richland, Wash. Quadrangle 195115 Minute

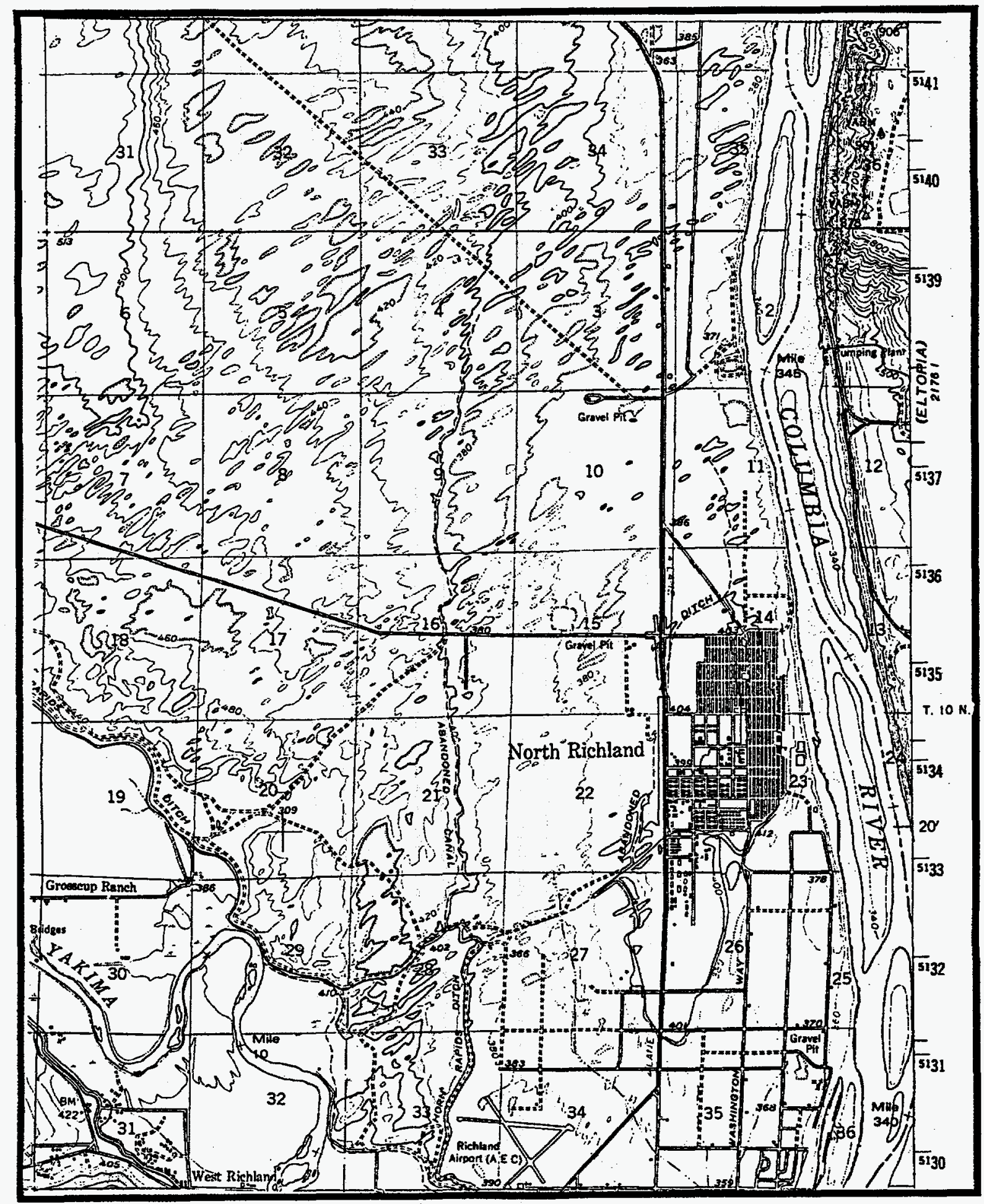

Figure C.2. Pre-Manhattan Project Landscape Where the Future 300 Area Would be Constructed 


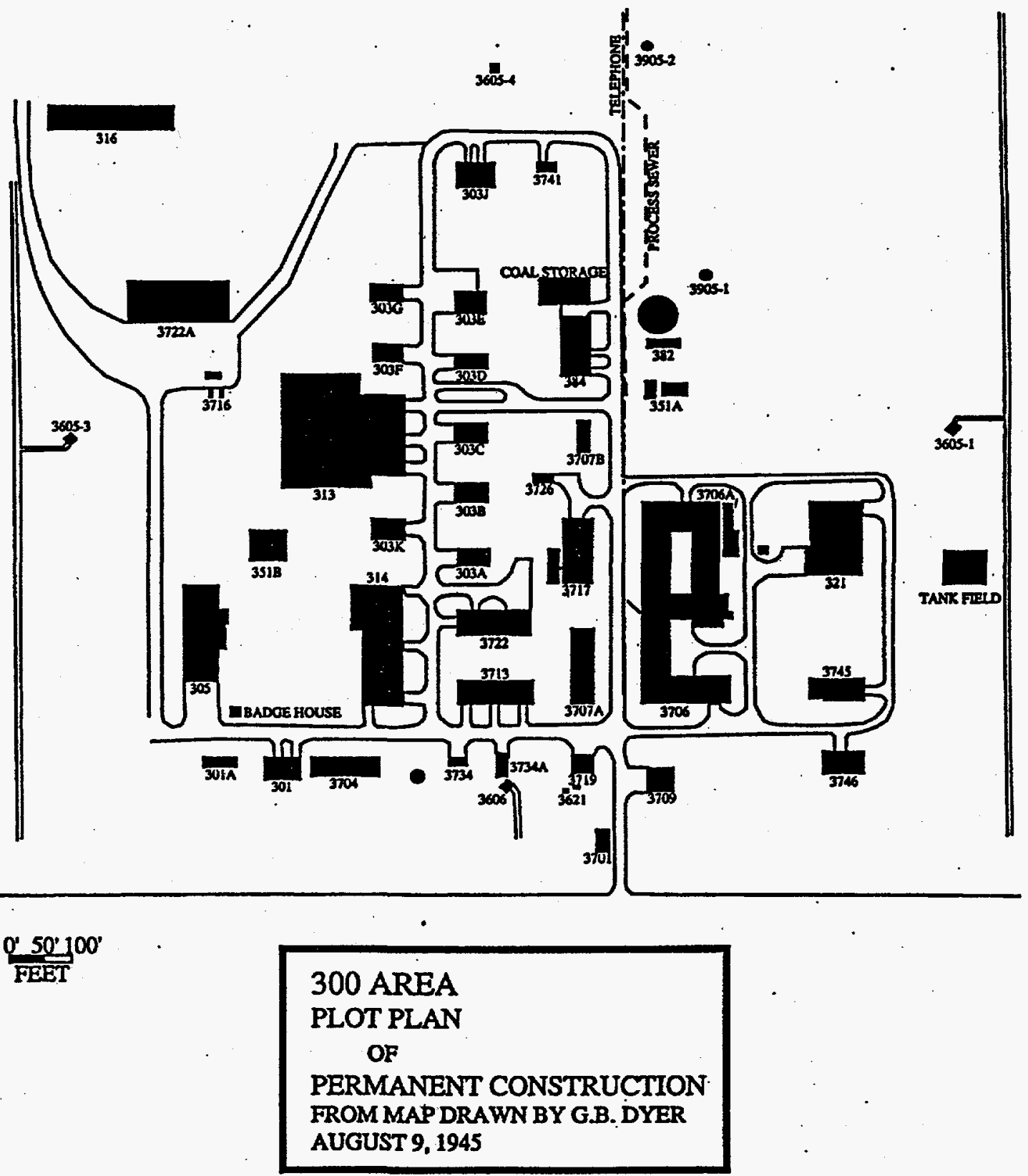

Figure C.3. Early Map of the 300 Area Adapted from E. I. Du Pont De Nemours \& Company, Inc. Map August 1945 


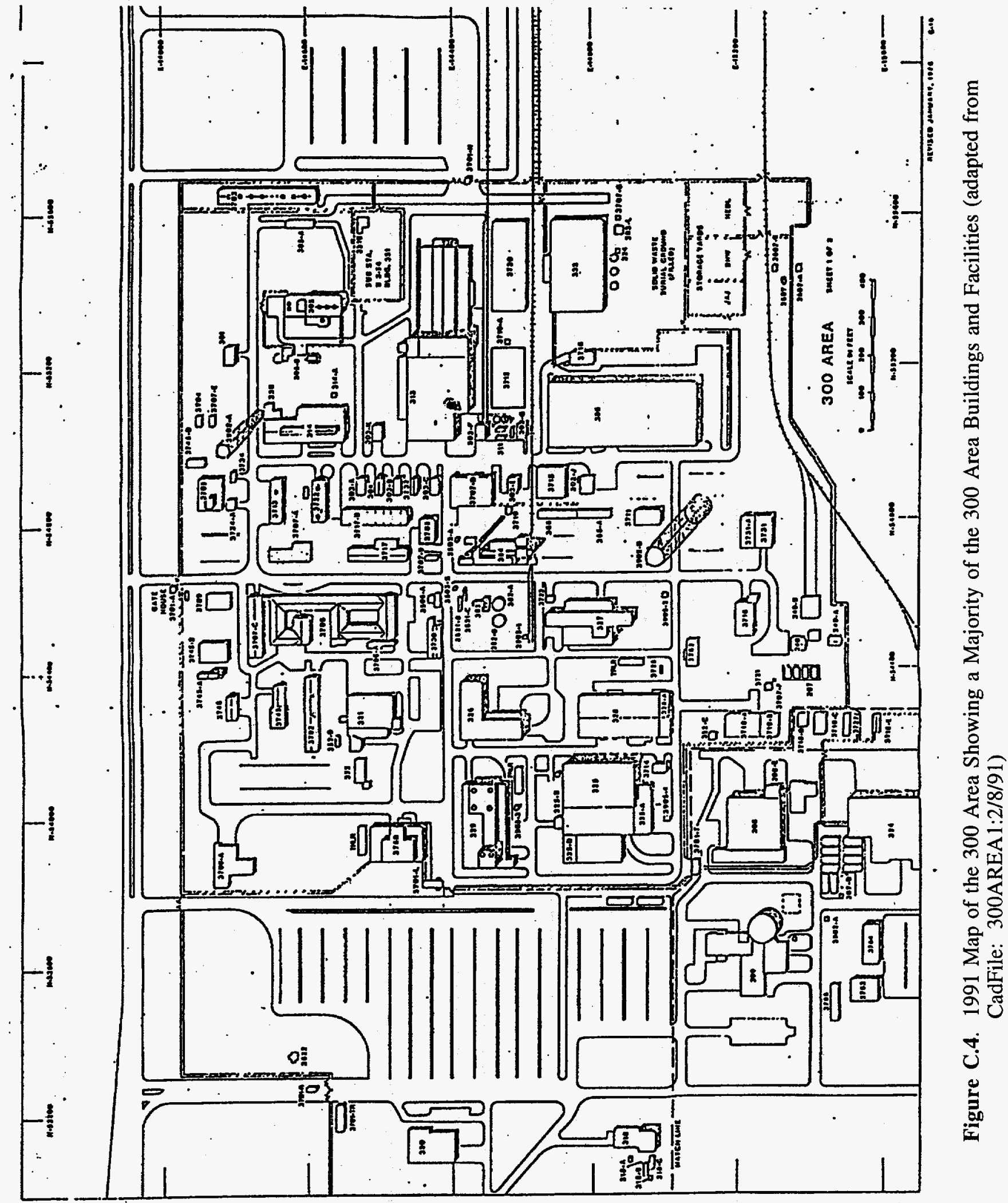

C. 4 


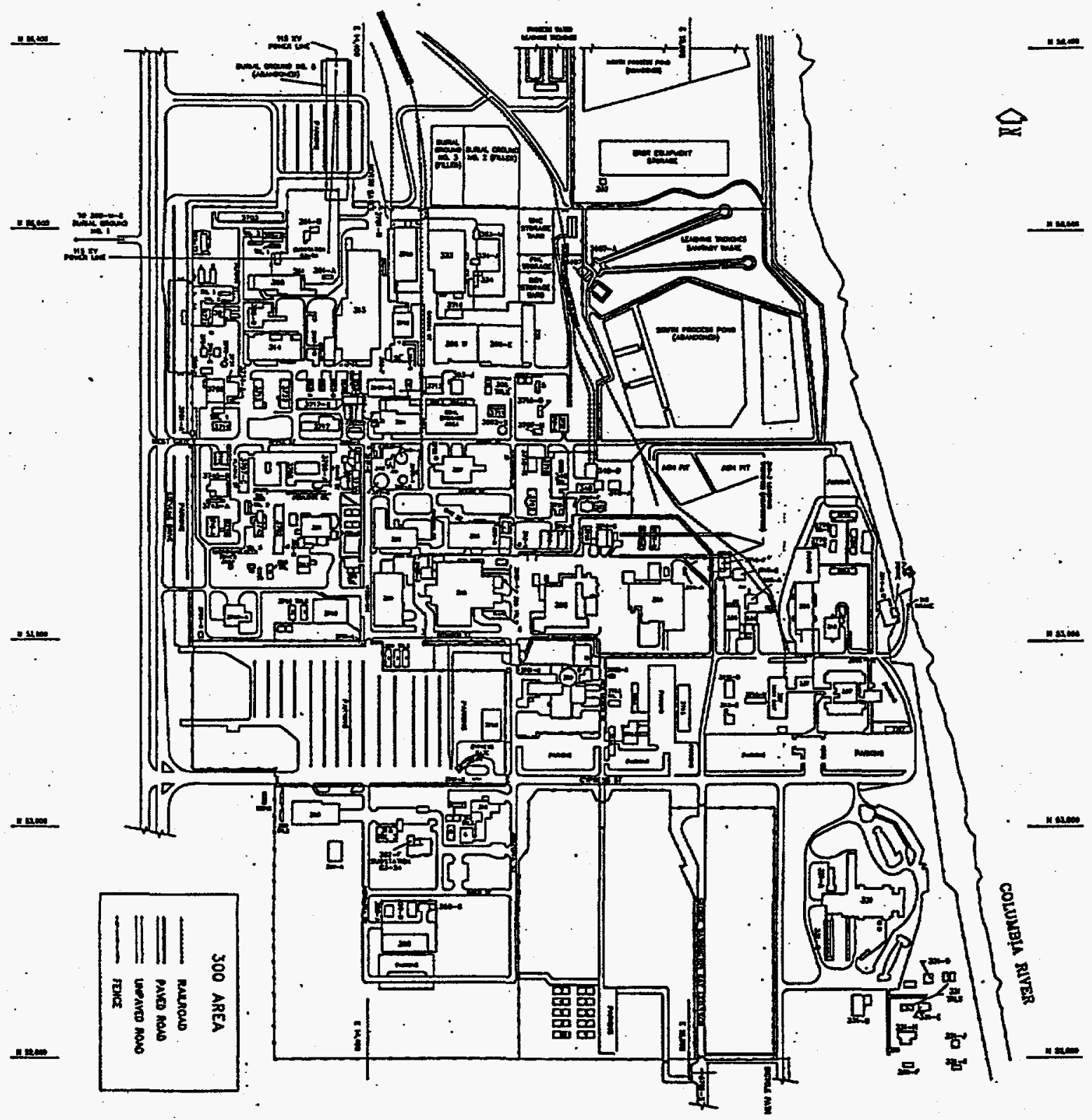

Figure C.5. 1991 Map of the 300 Area Showing a Majority of the 300 Area Buildings and Facilities (adapted from CadFile: 300AREA1:2/8/91) 


\section{Appendix D}

300 Area: Facilities Evaluation of Disturbance 


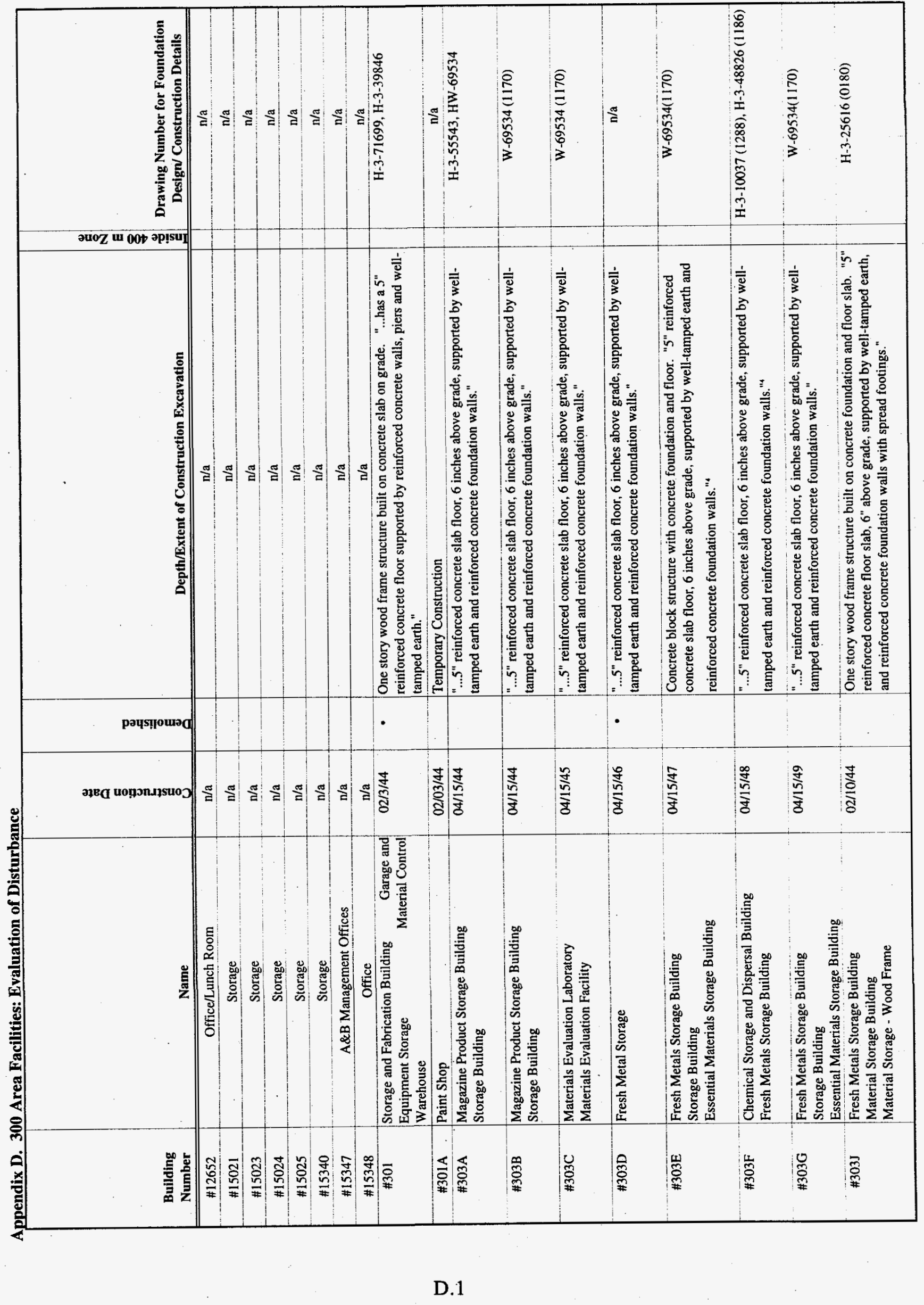




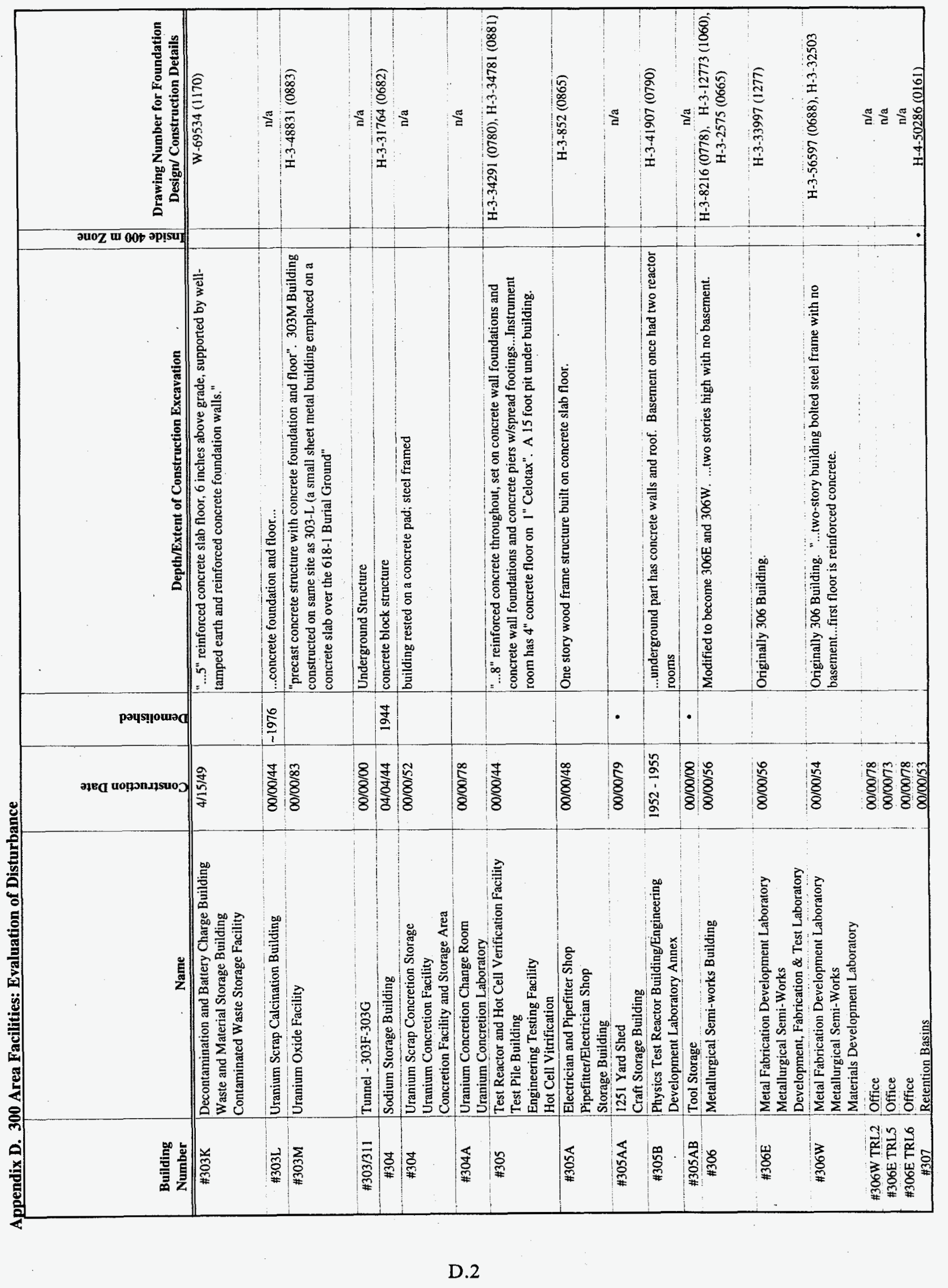




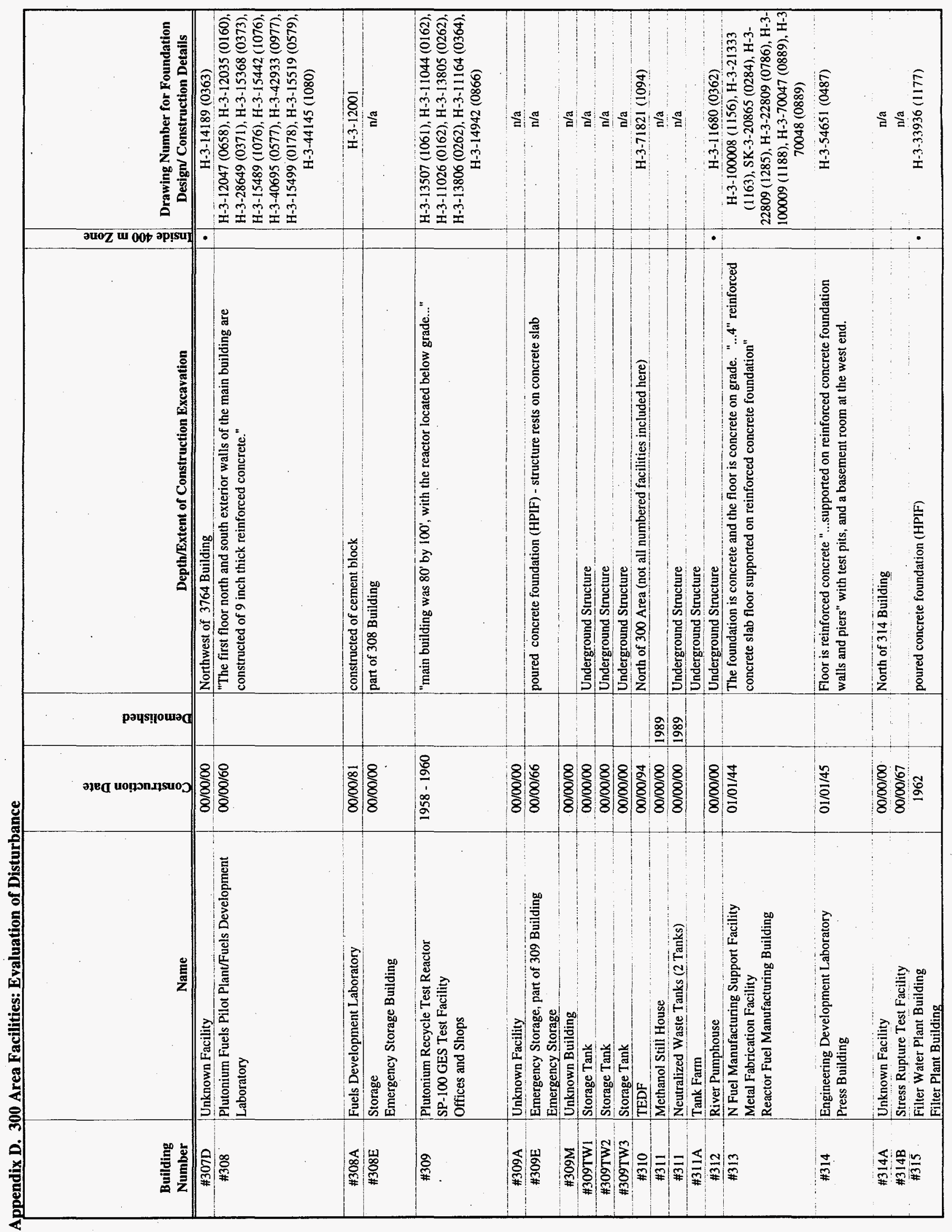

D. 3 


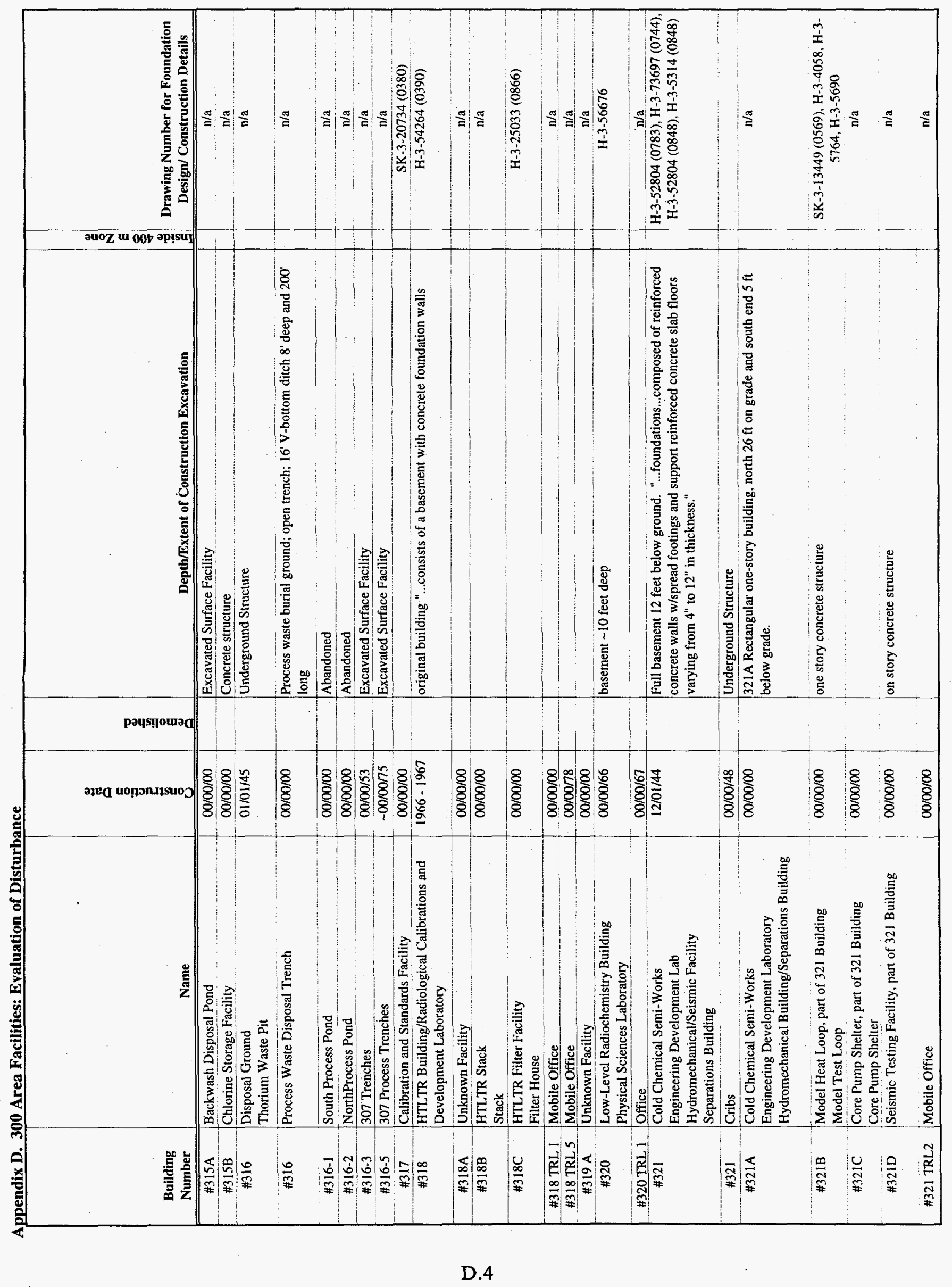




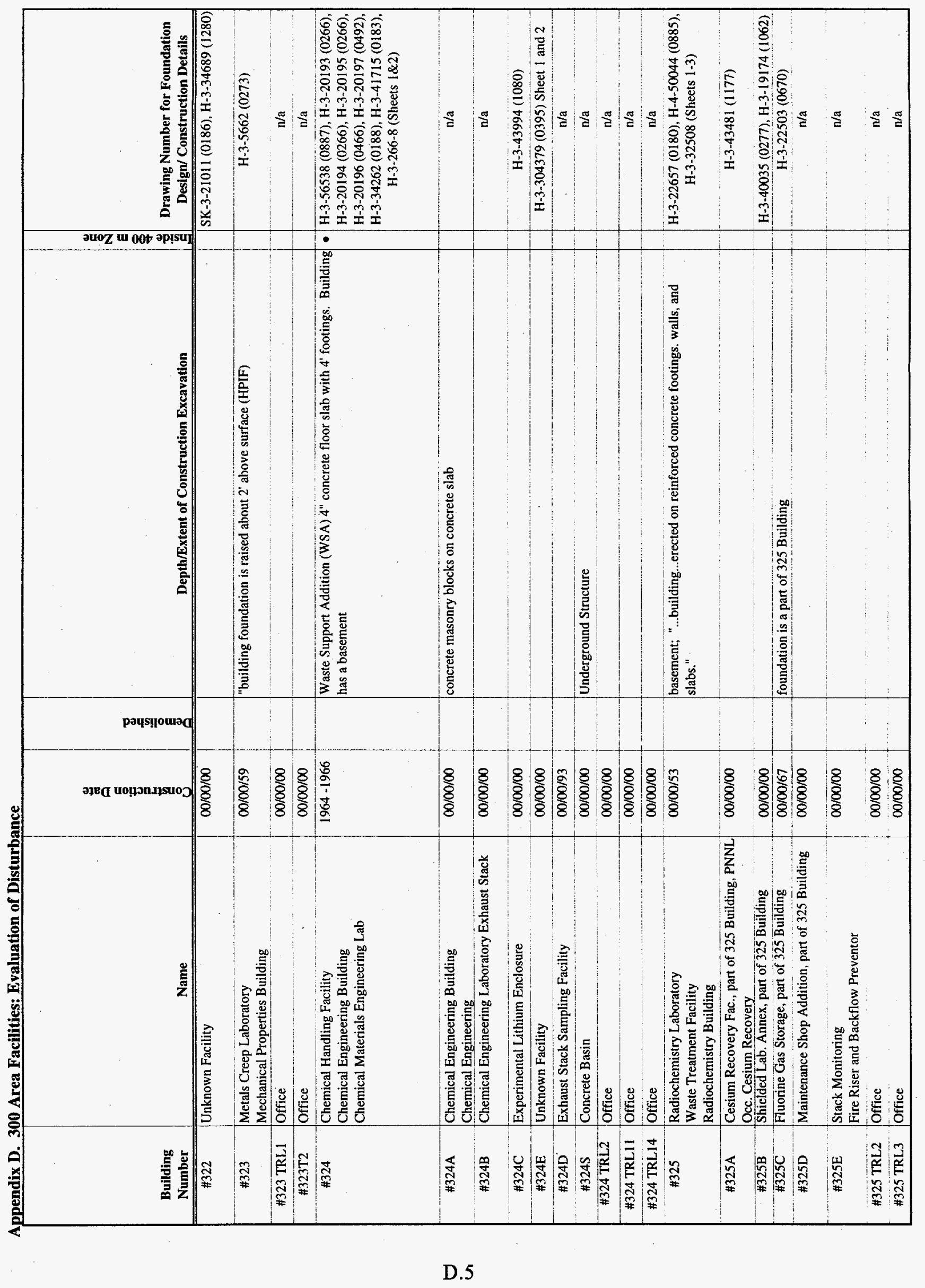




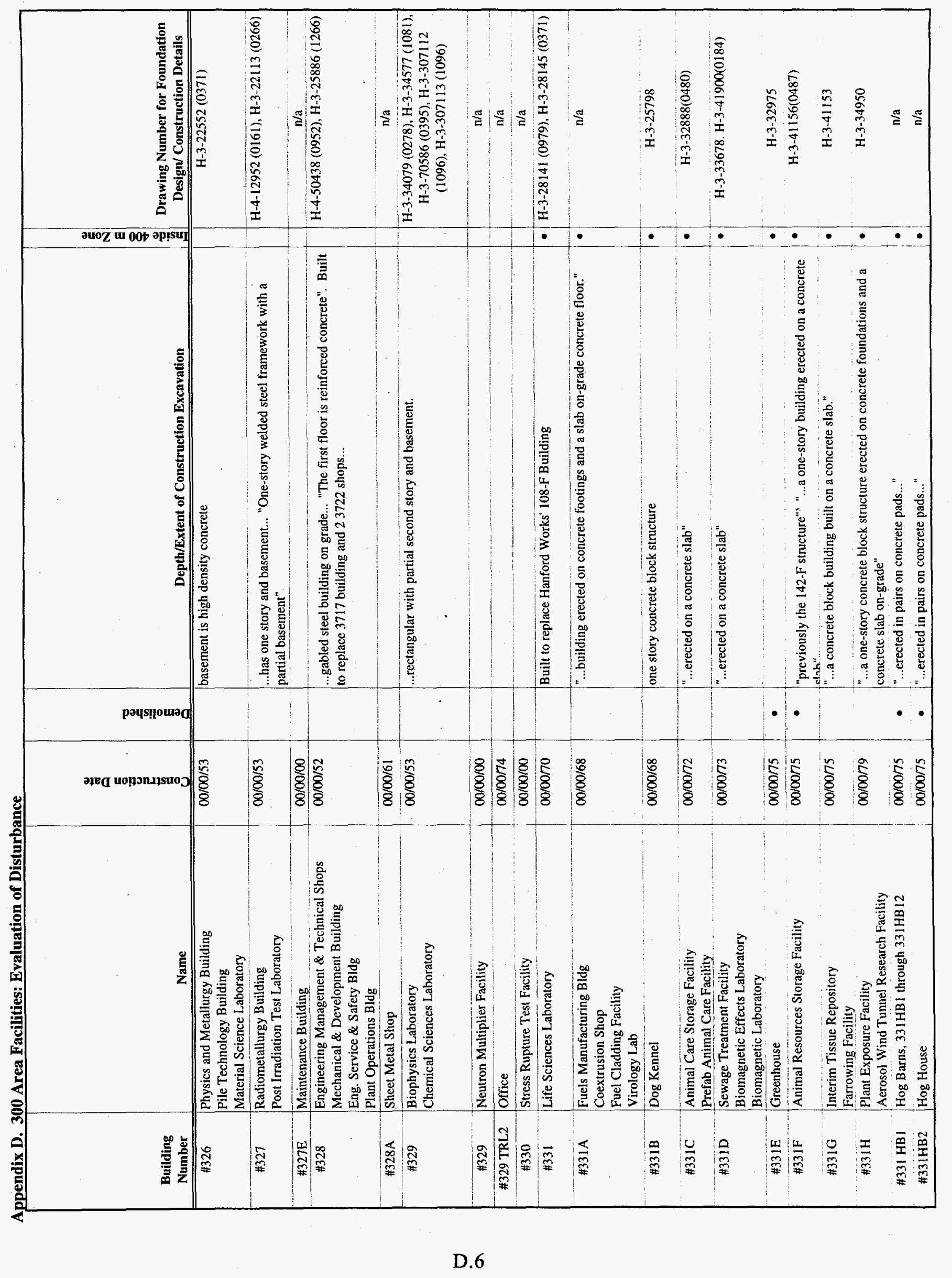




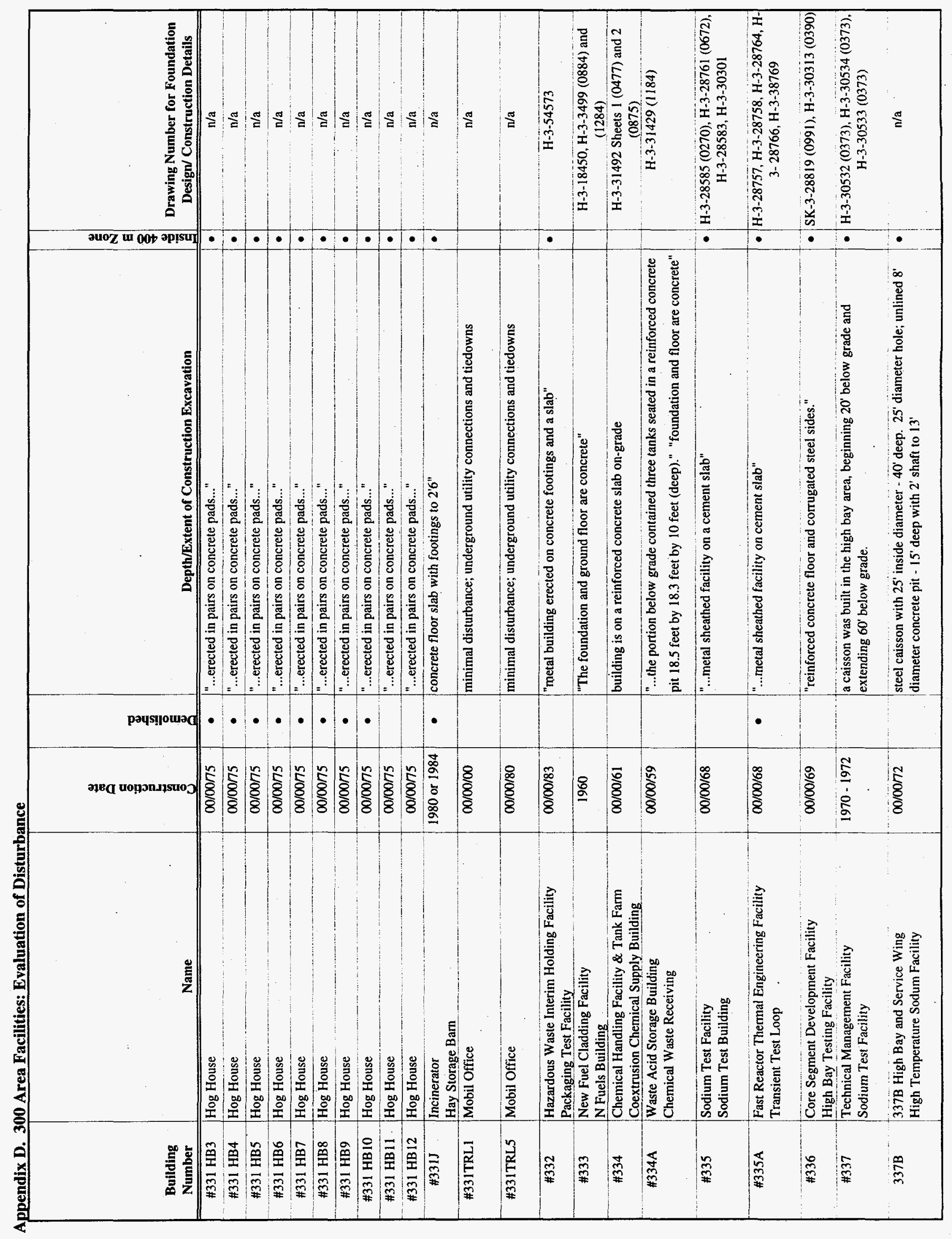

D. 7 


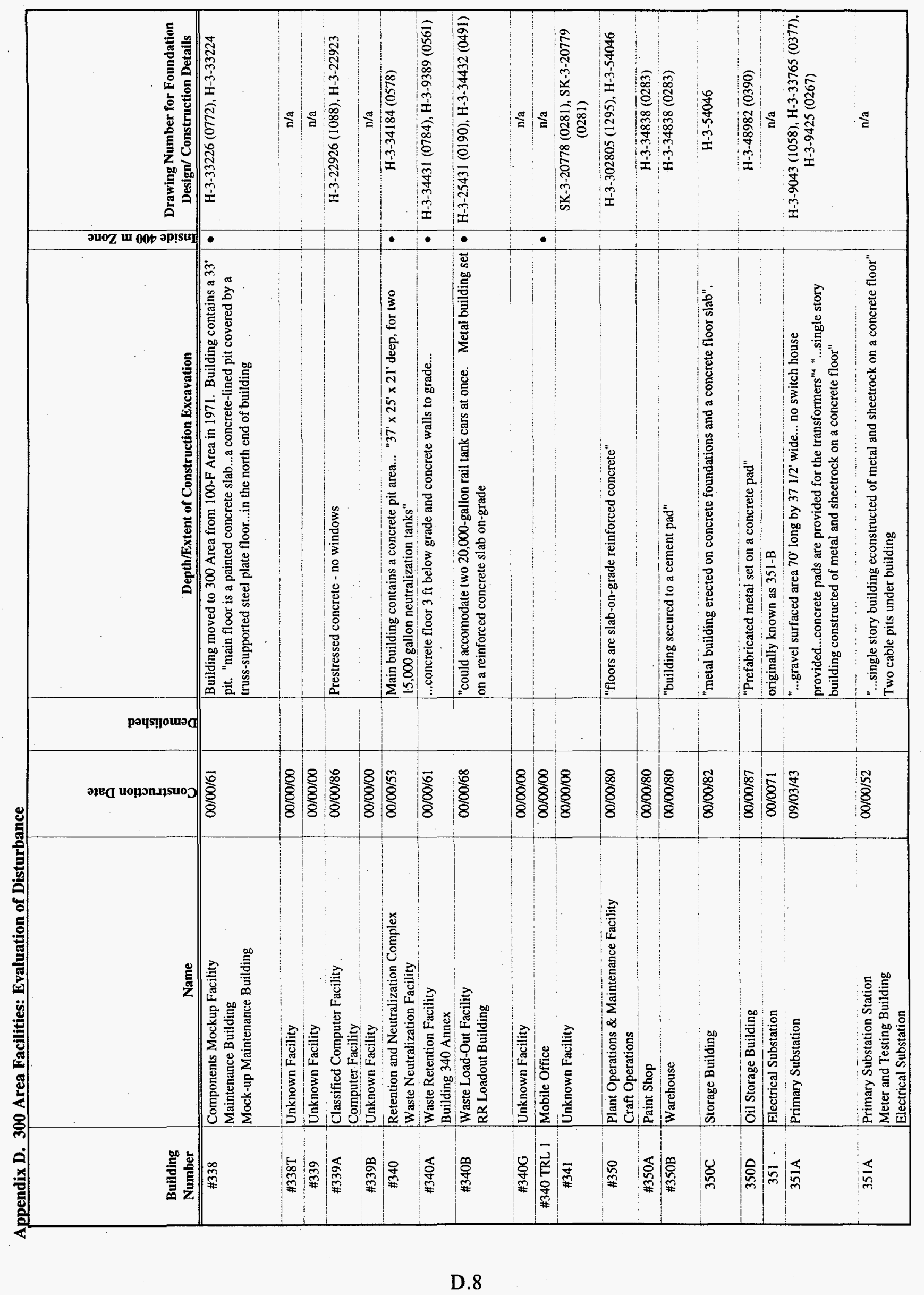




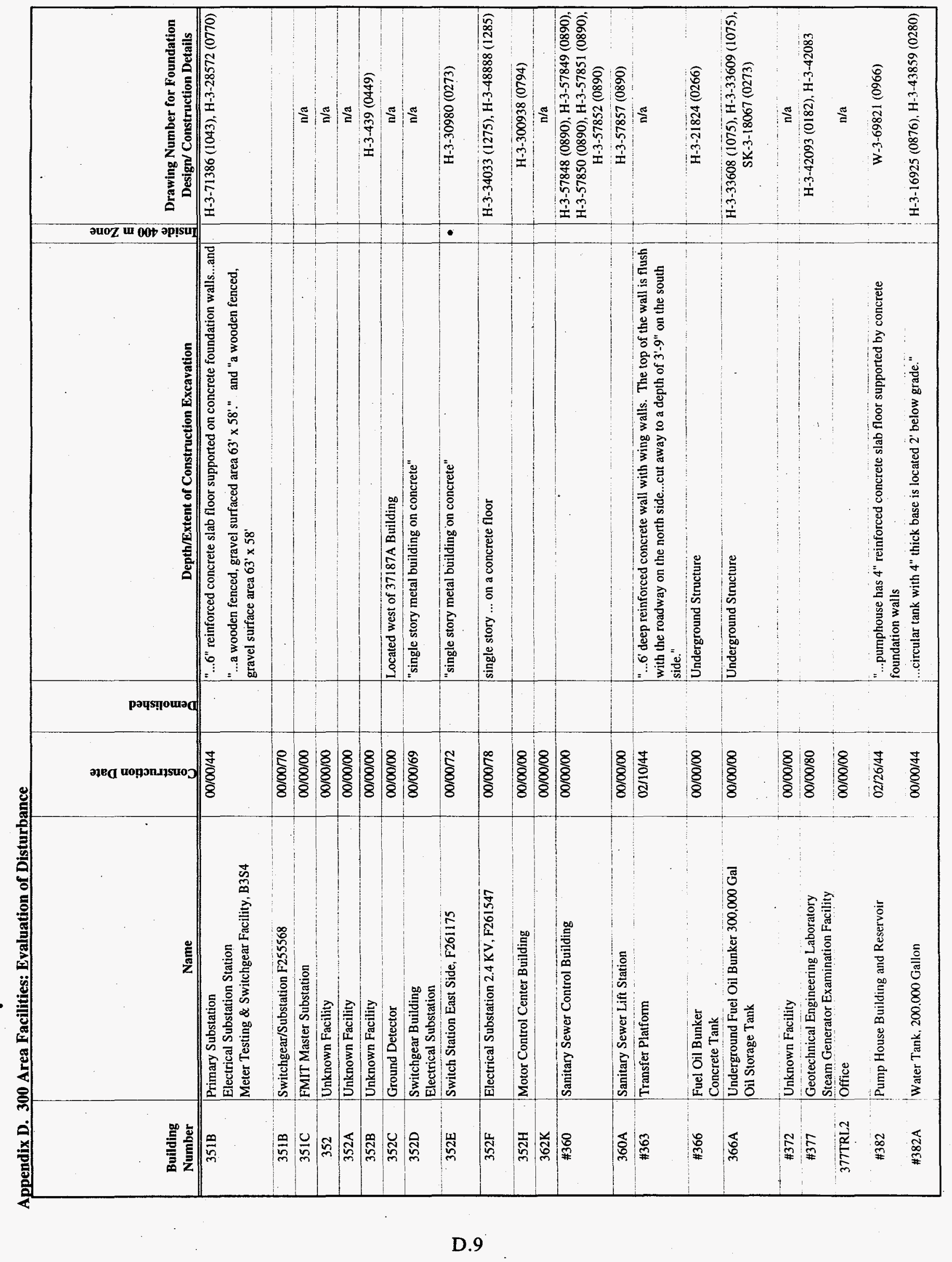




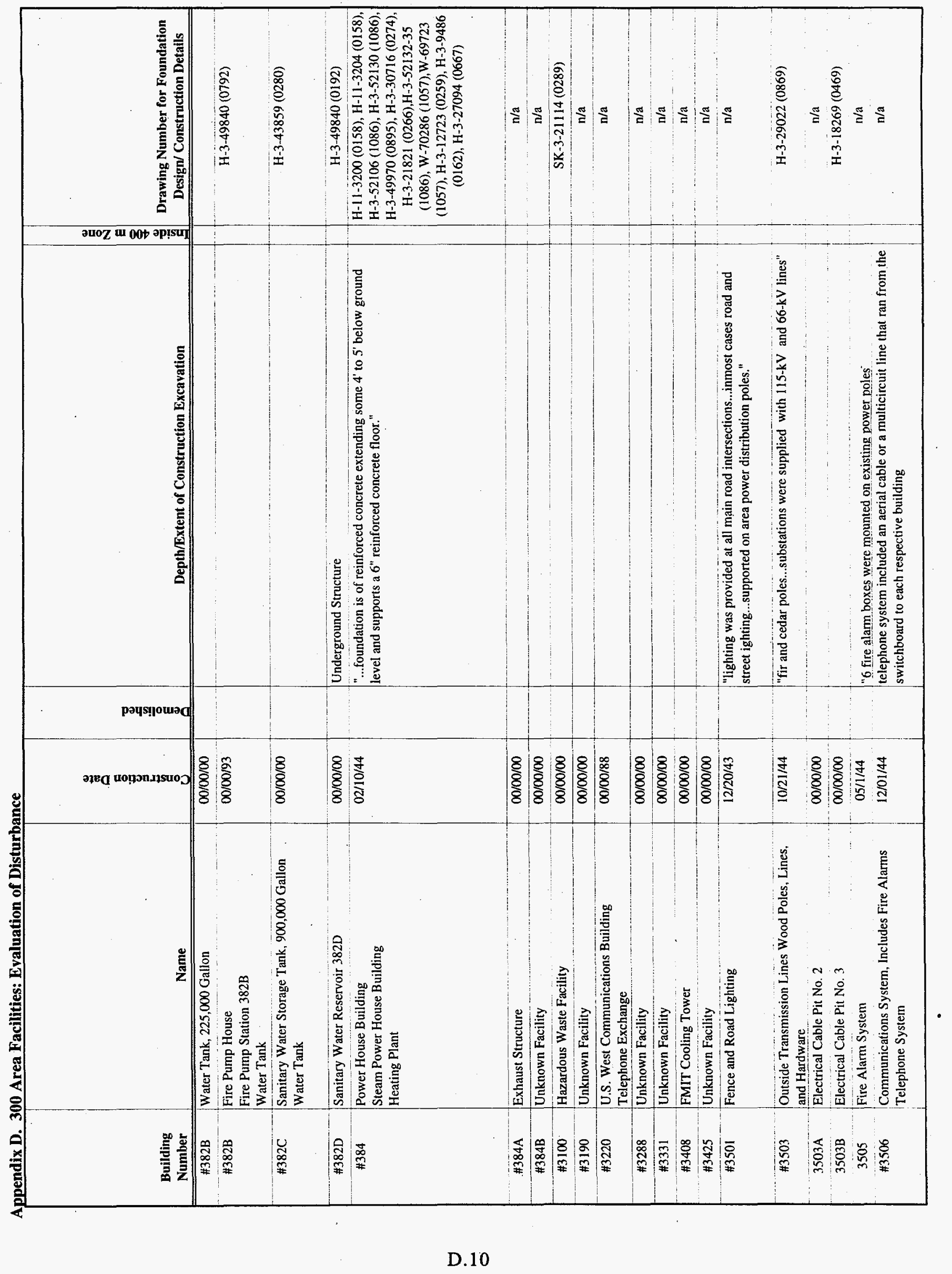




\begin{tabular}{|c|c|c|c|c|c|c|c|c|c|c|c|c|c|c|}
\hline 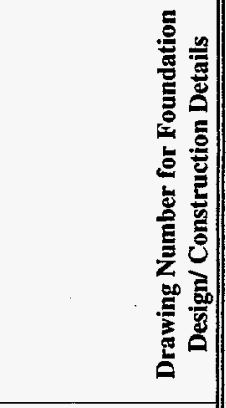 & 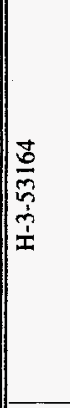 & $\Xi$ & 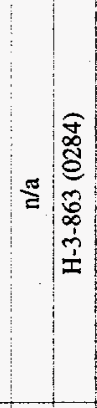 & 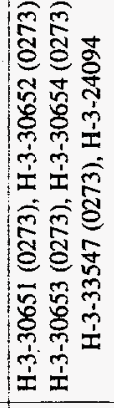 & $\stackrel{\Perp}{\Perp}$. & 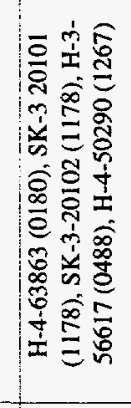 & 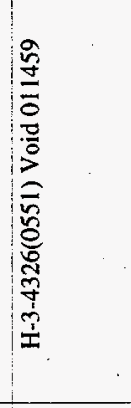 & $\cong$ & 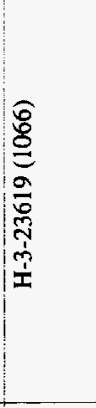 & 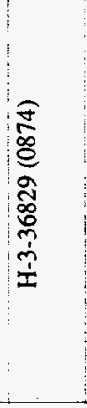 & 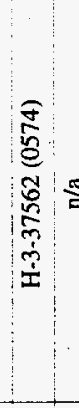 & & $\stackrel{\pi}{E}$ & 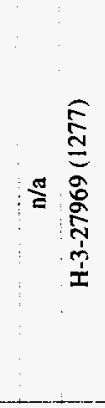 \\
\hline 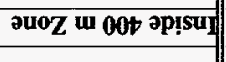 & & & $\bullet$ & $\cdot$ & & & $\bullet$ & & 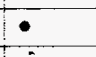 & $\bullet$ & & & & $\bullet$ \\
\hline 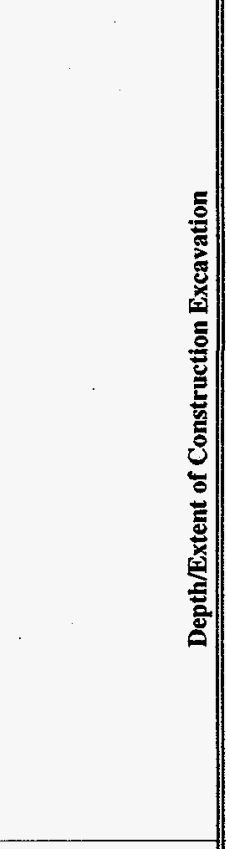 & 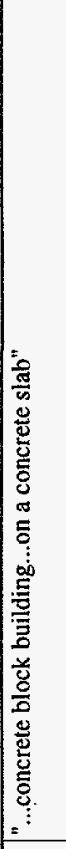 & & 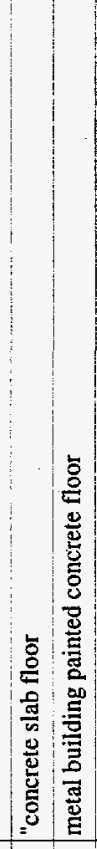 & 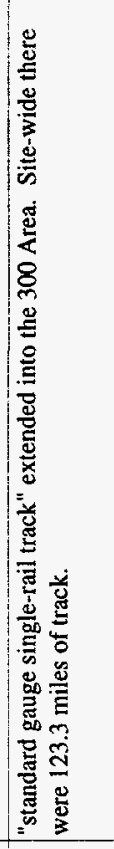 & 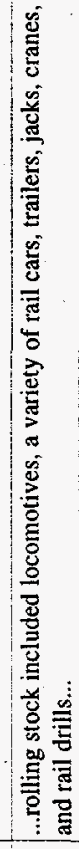 & 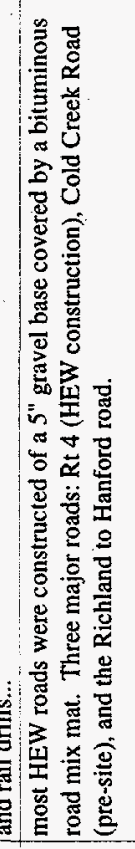 & 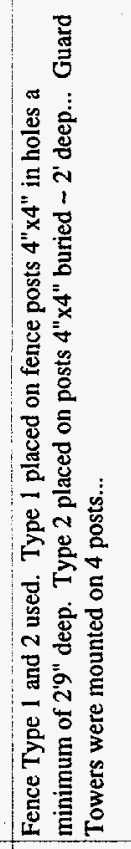 & & 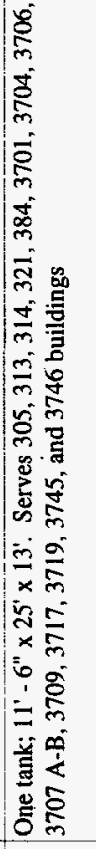 & & & 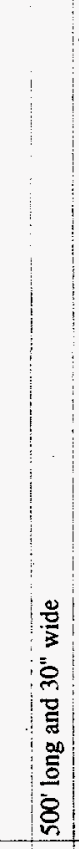 & 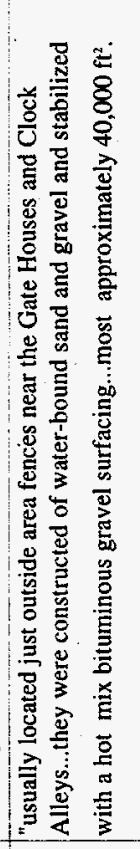 & 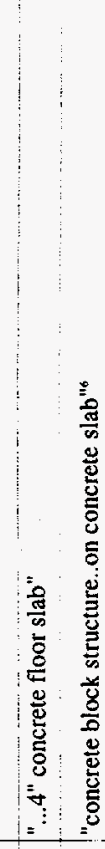 \\
\hline \multicolumn{15}{|l|}{ payș̣lowa } \\
\hline มีEQ uop̣nnsusuod & $\frac{8}{8}$ & $\frac{8}{8}$ & $\begin{array}{l}\infty \\
0 \\
0 \\
0 \\
8 \\
8 \\
8\end{array}$ & $\frac{7}{2}$ & 8 & $\frac{1}{8}$ & 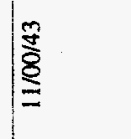 & 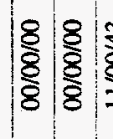 & $\frac{7}{8}$ & 8 & & 8 & $\frac{8}{8}$ & $\frac{8}{8}$ \\
\hline 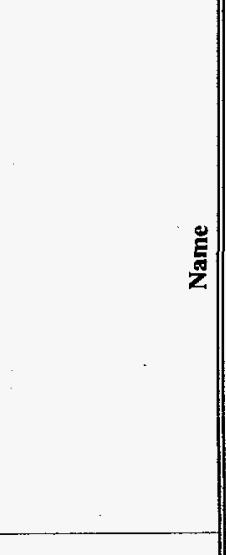 & 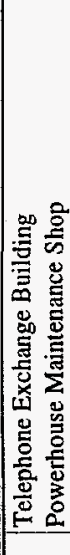 & 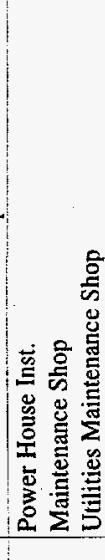 & 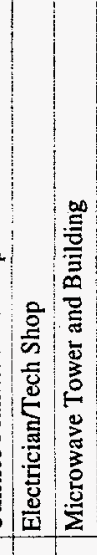 & 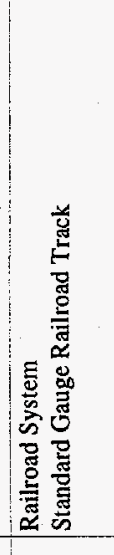 & 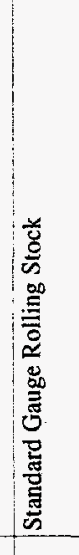 & 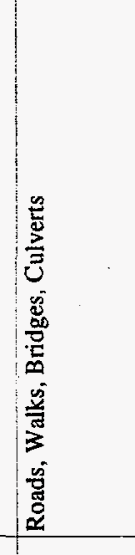 & 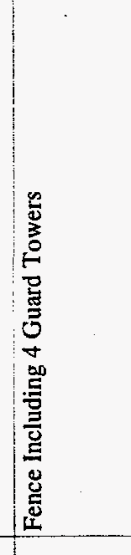 & 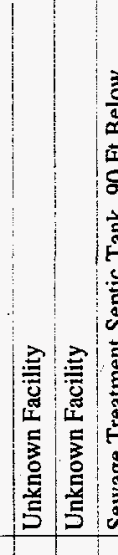 & 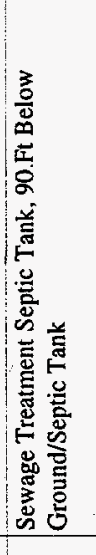 & 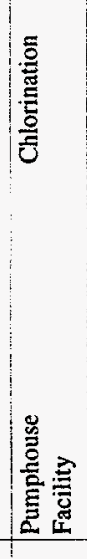 & 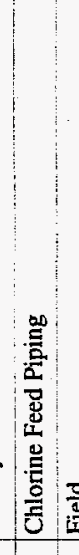 & 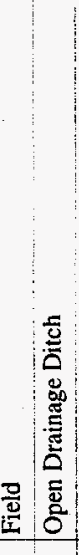 & $\approx$ & 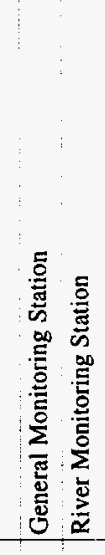 \\
\hline 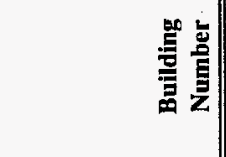 & 逽 & 密 & 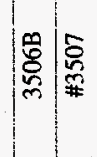 & 屟 & 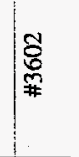 & 兽 & 管 & 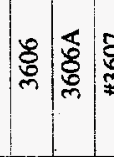 & 害 & 额 & 部 & & 豆 & 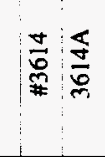 \\
\hline
\end{tabular}

D. 11 


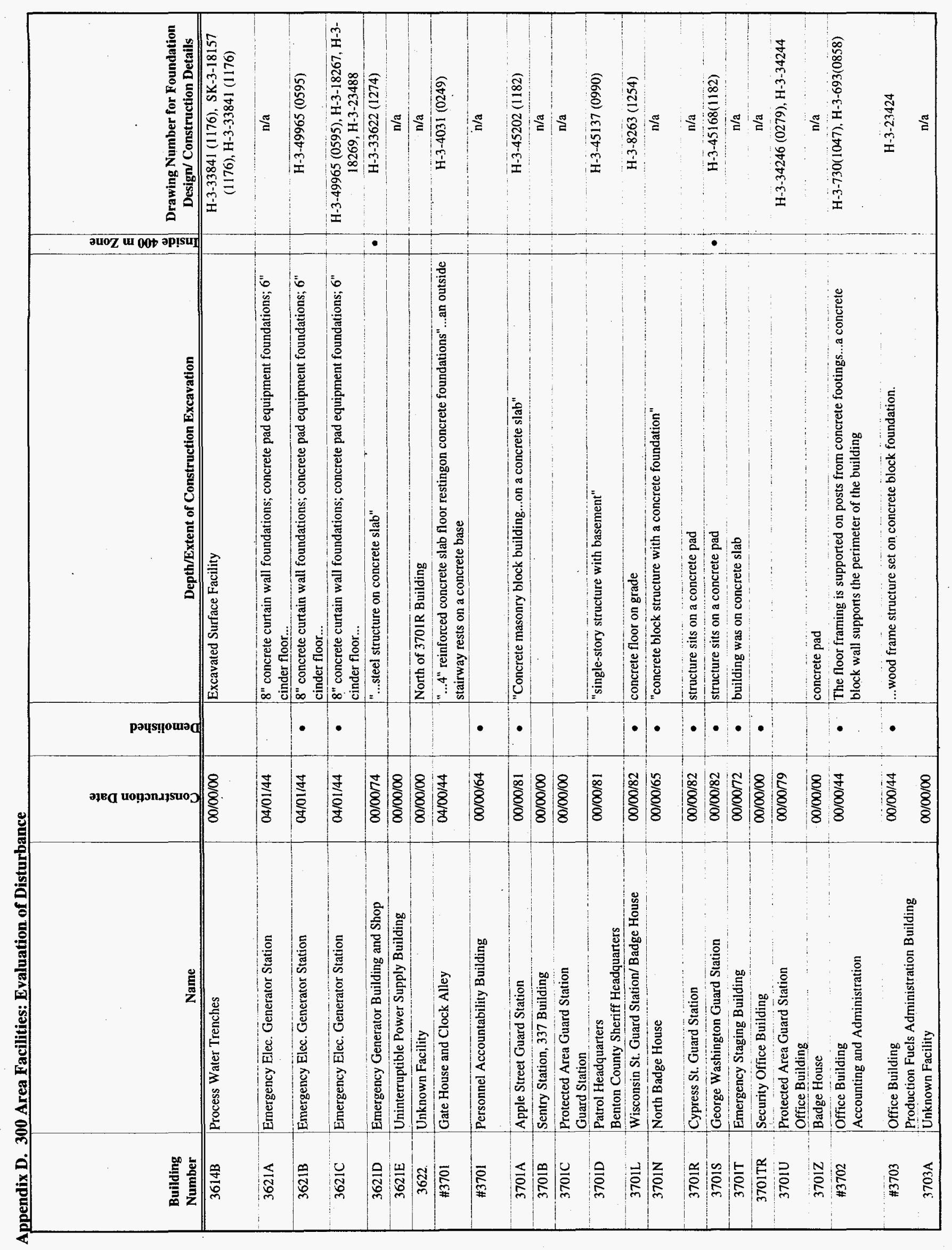

D. 12 


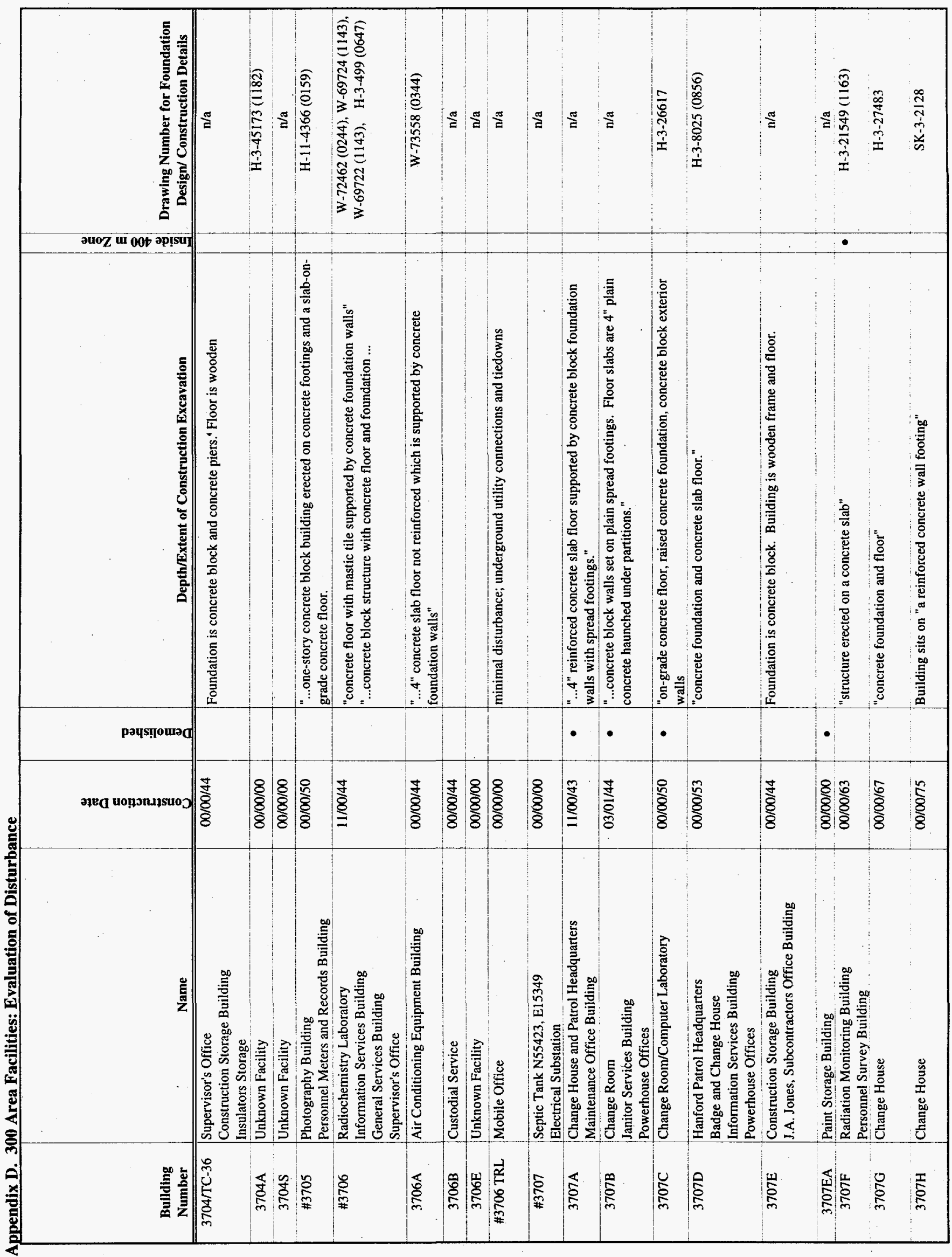

D.13 


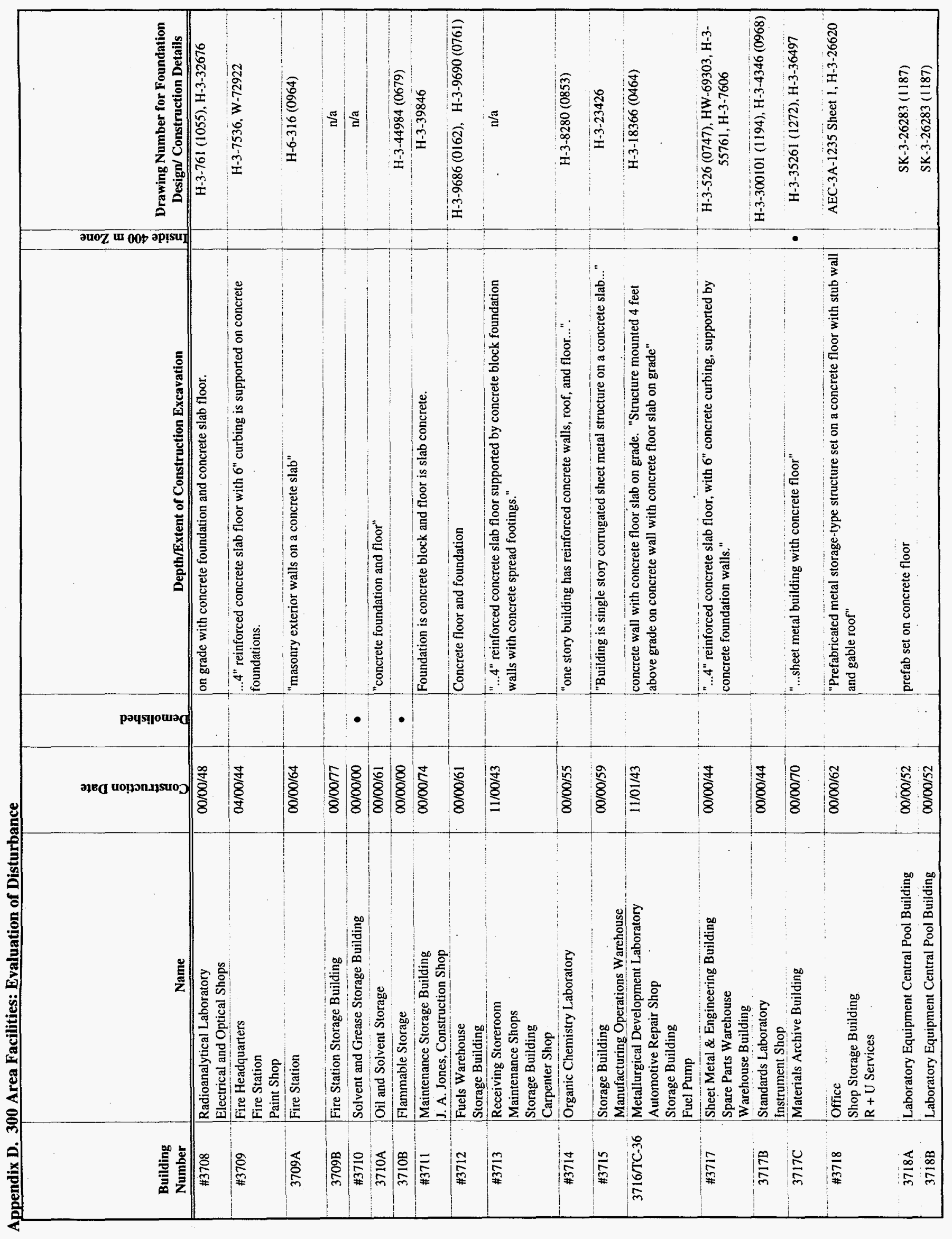

D. 14 


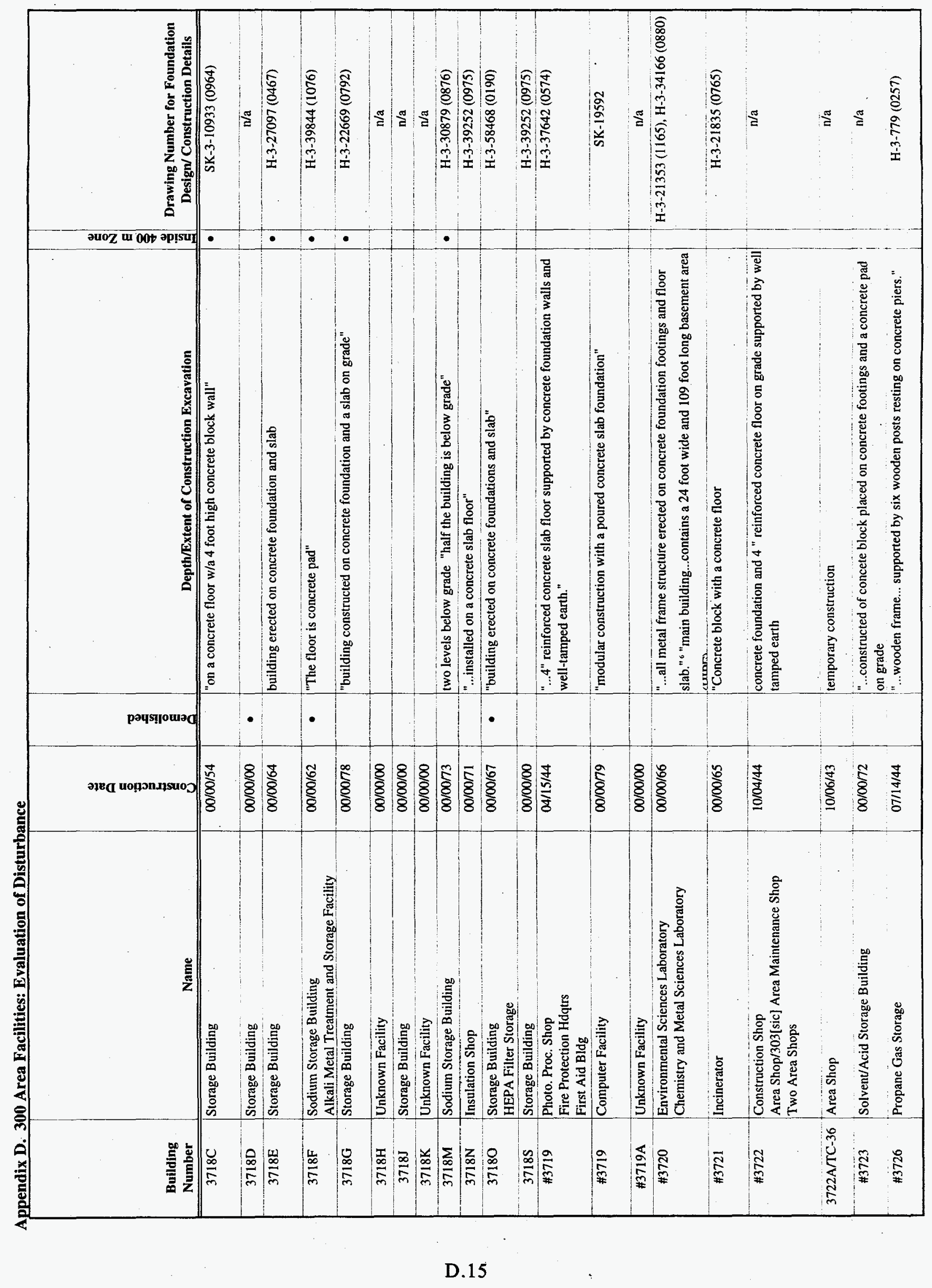




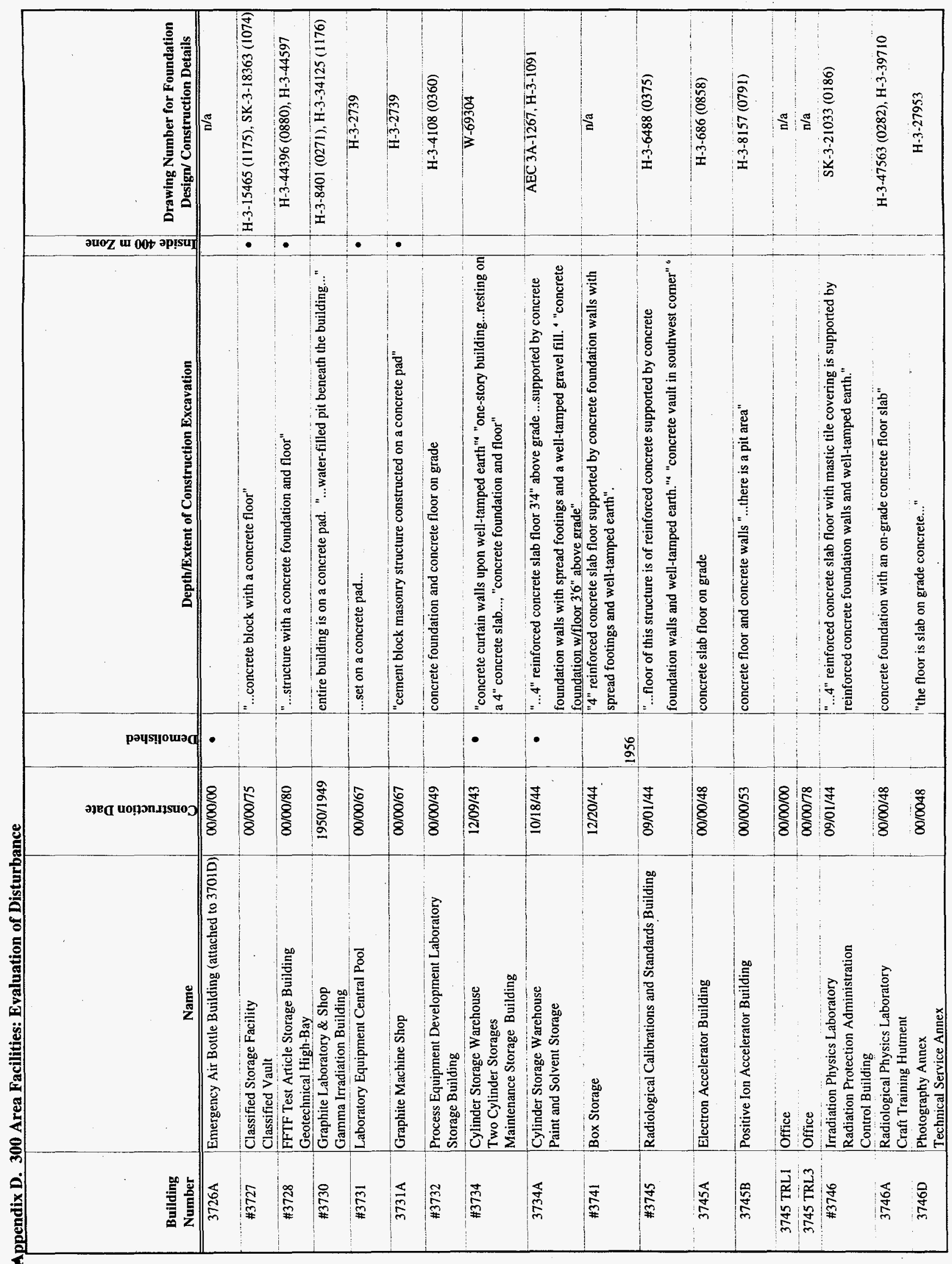

D. 16 


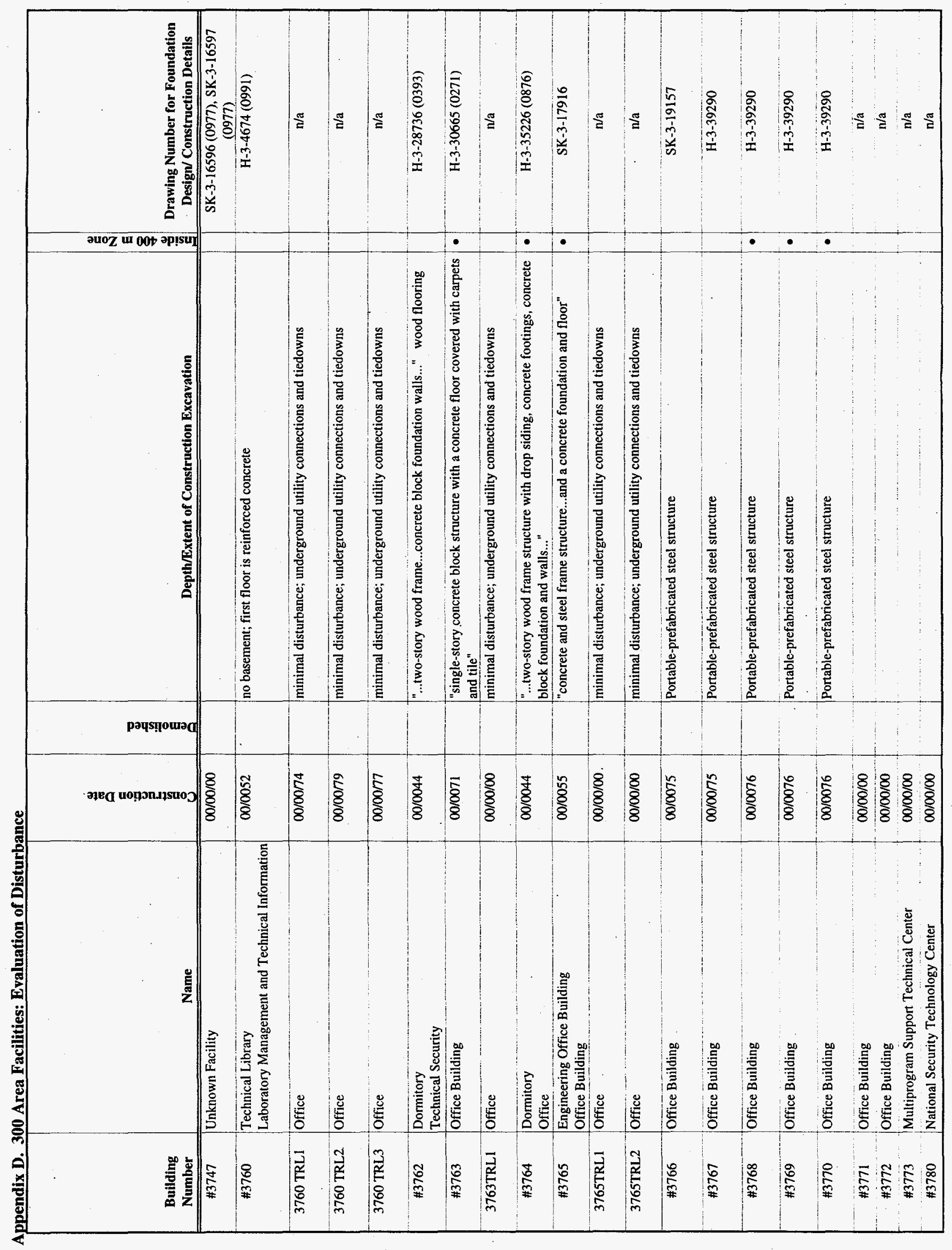

D. 17 


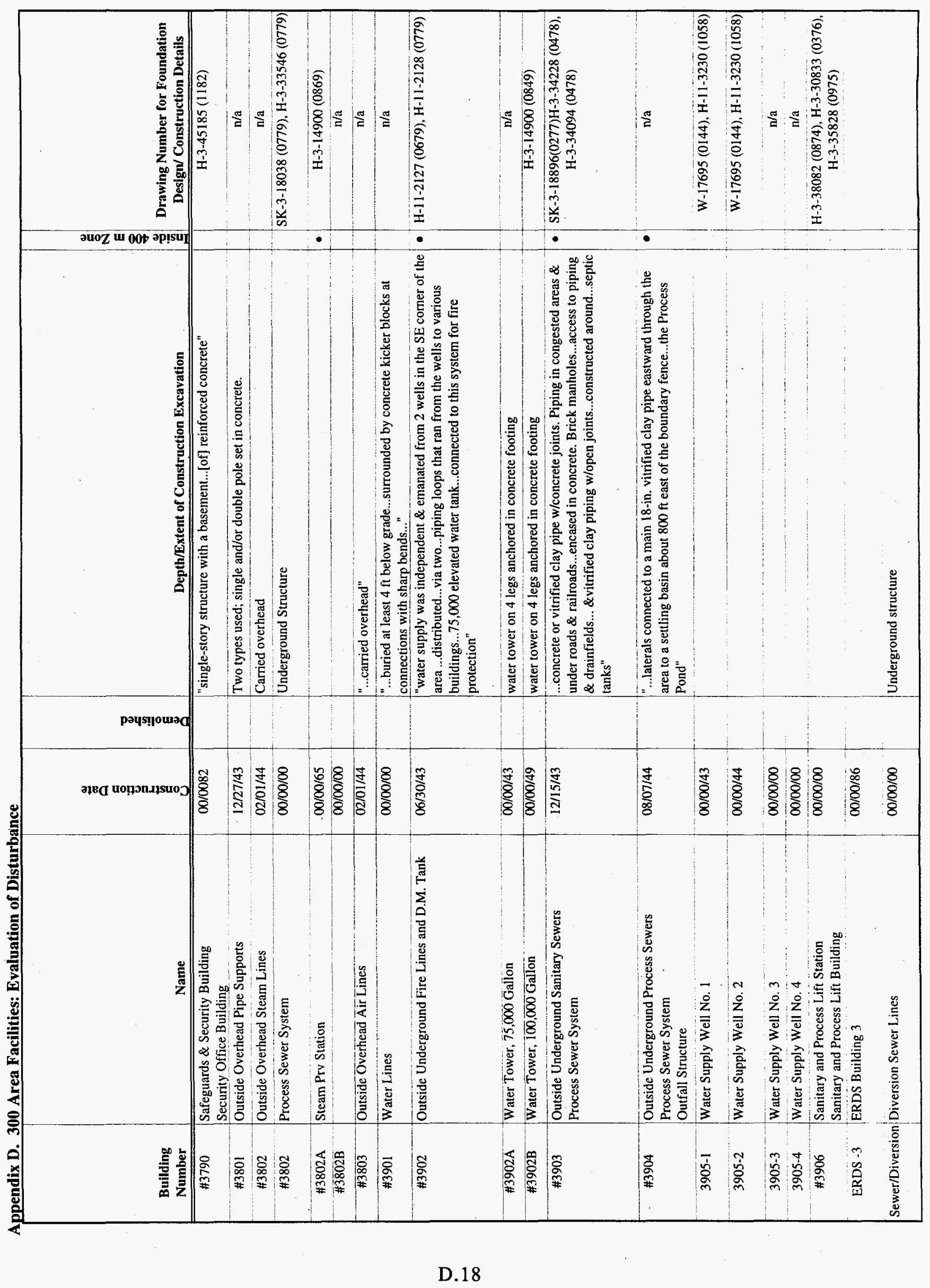




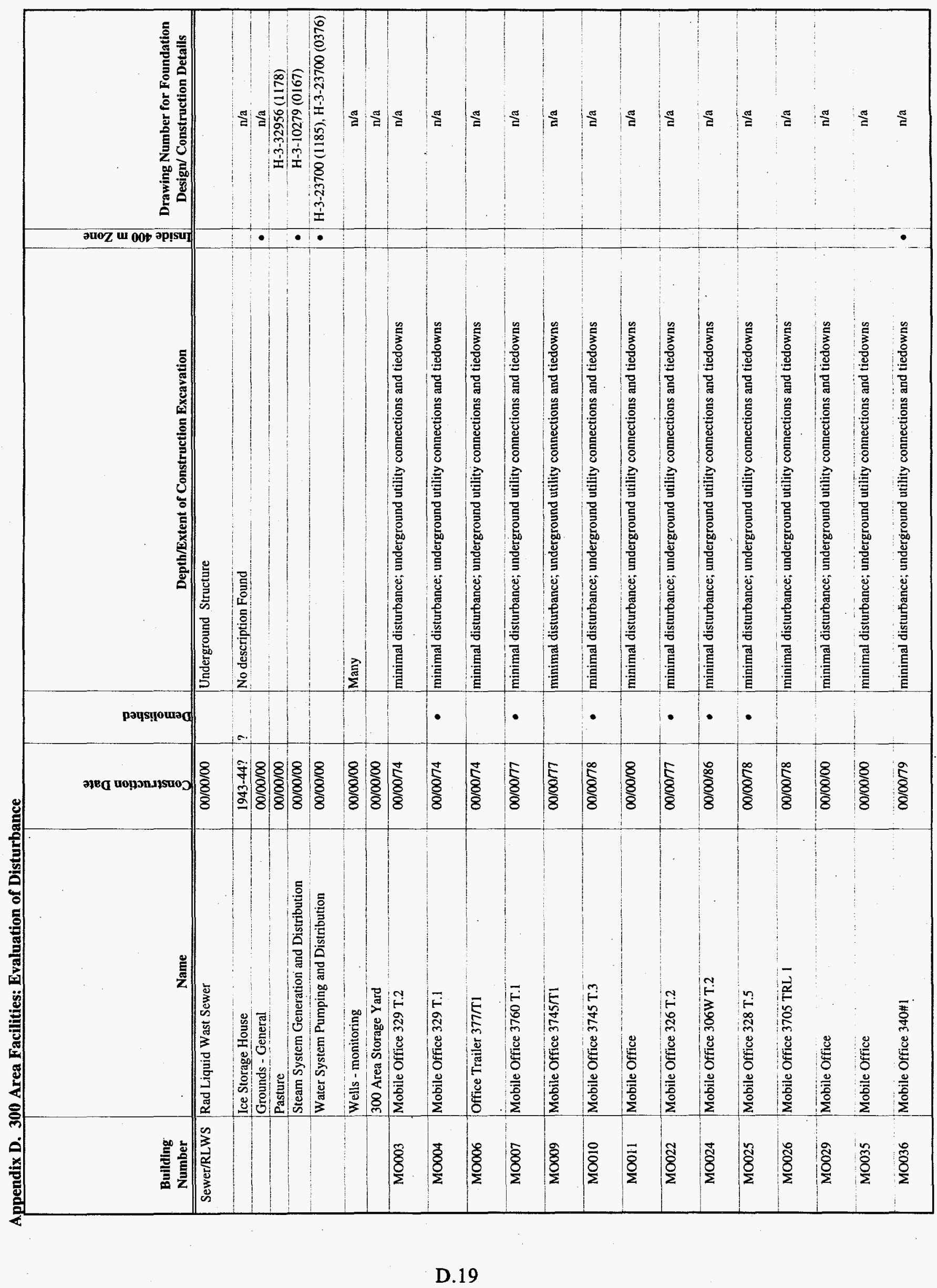




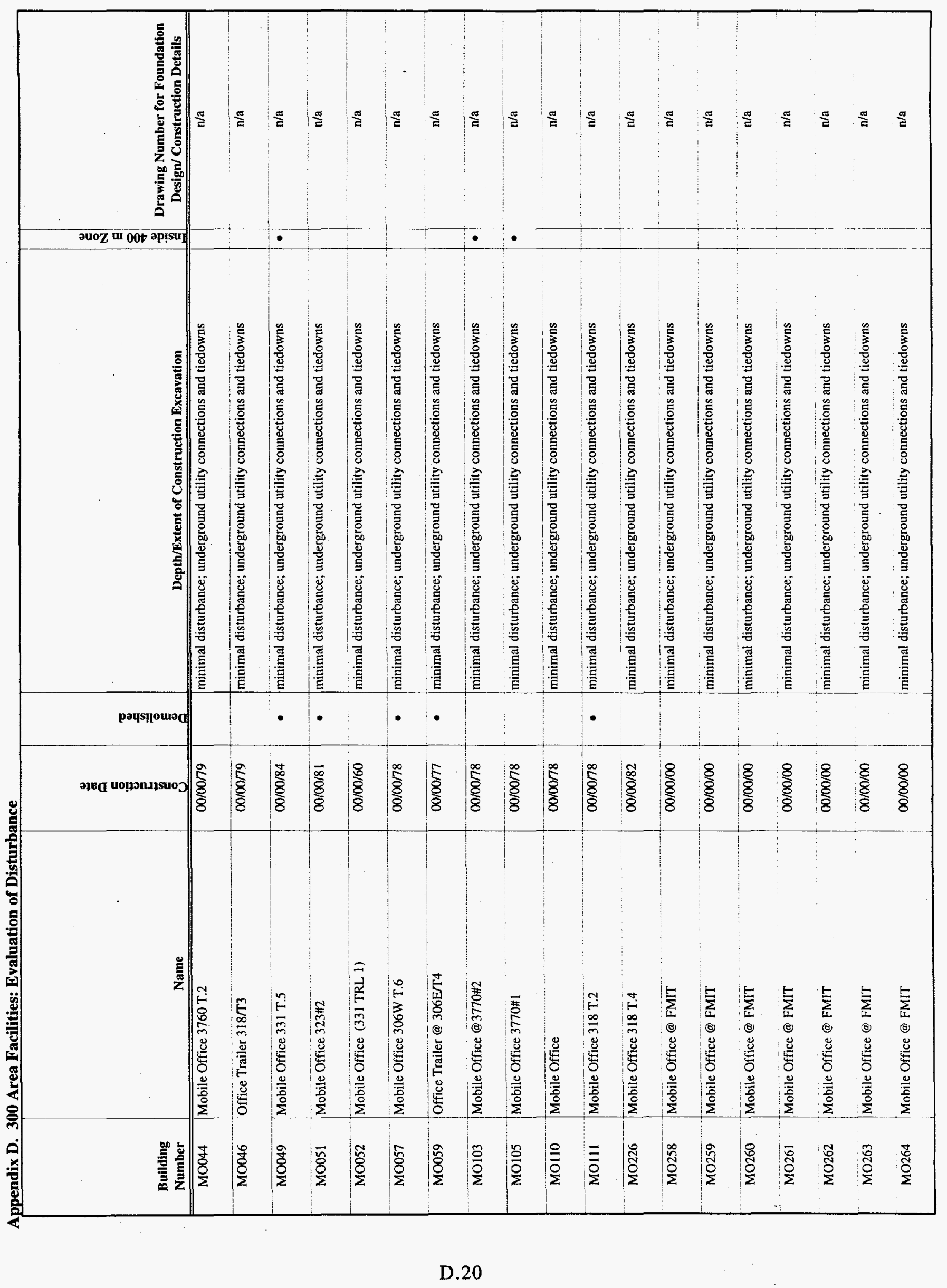




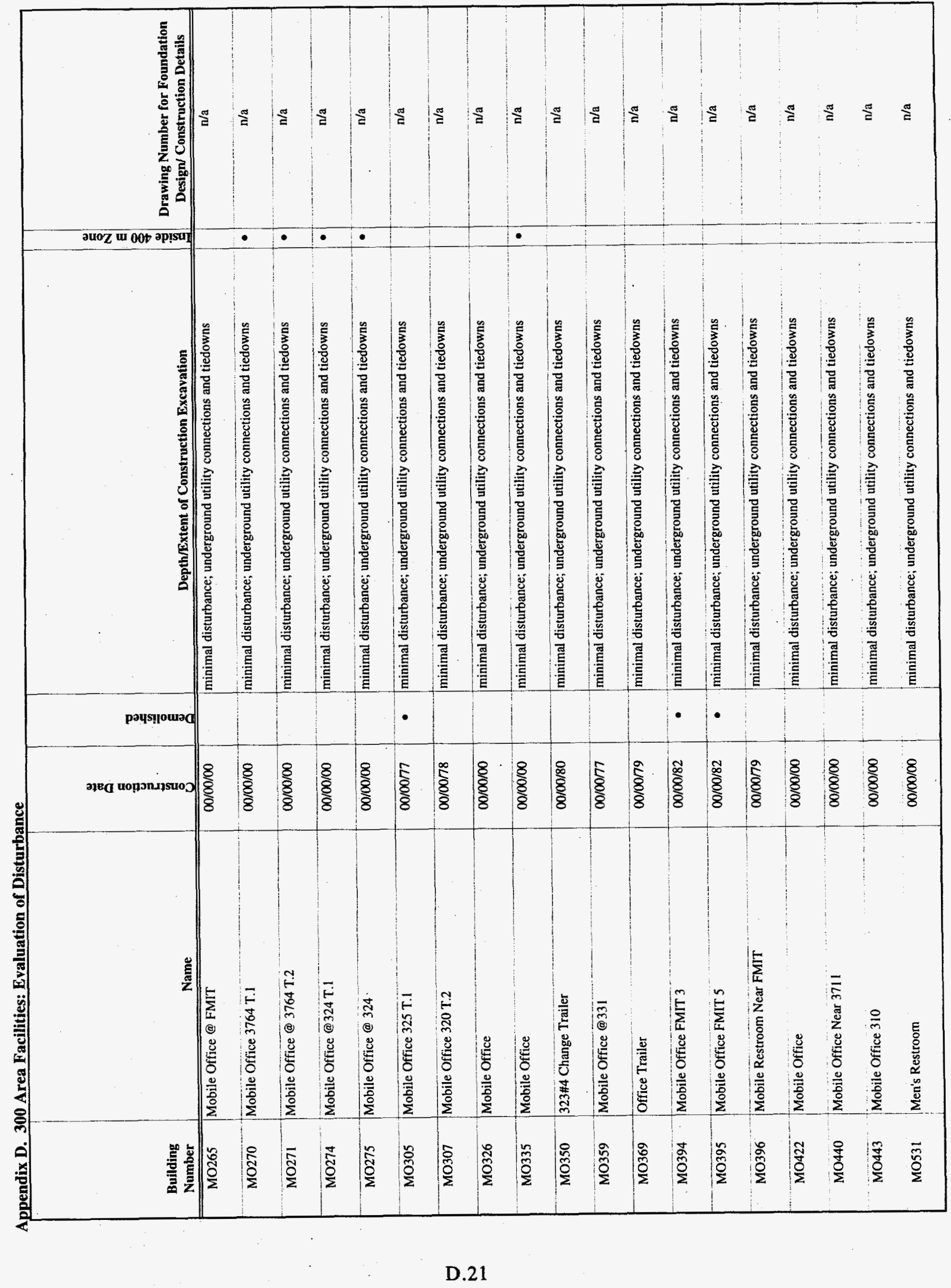




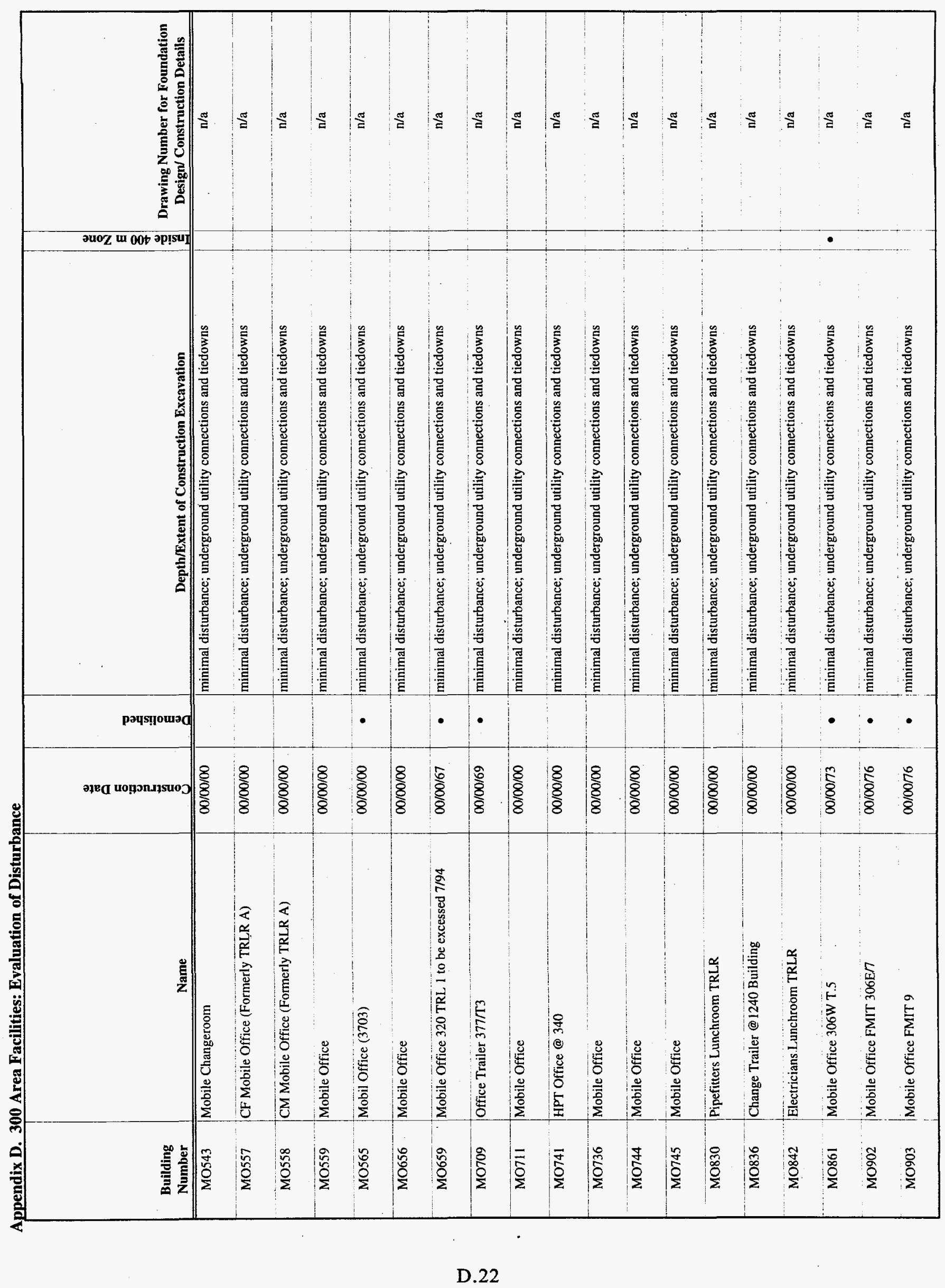




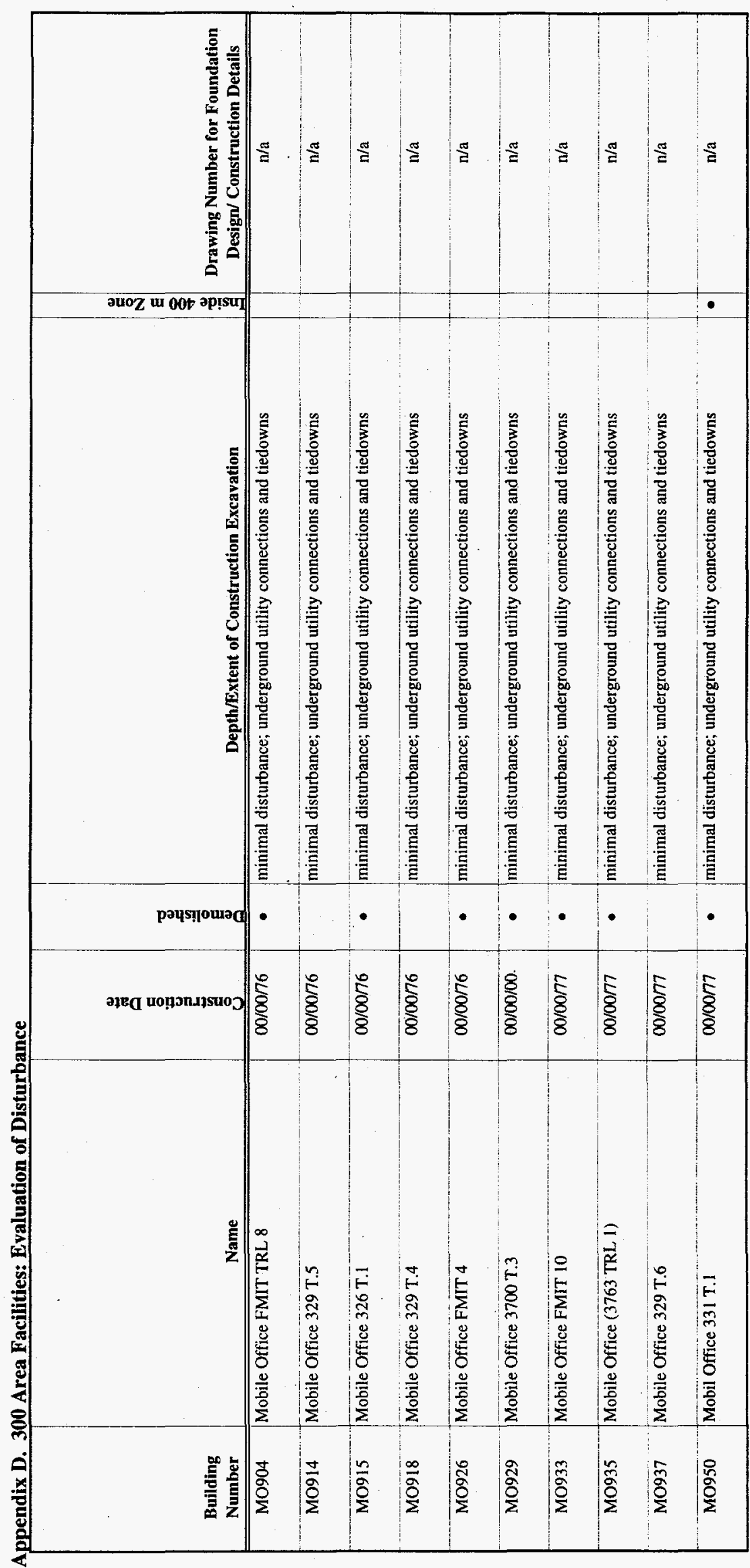

D. 23 
Appendix E

300 Area: Well Log Deposit Records 


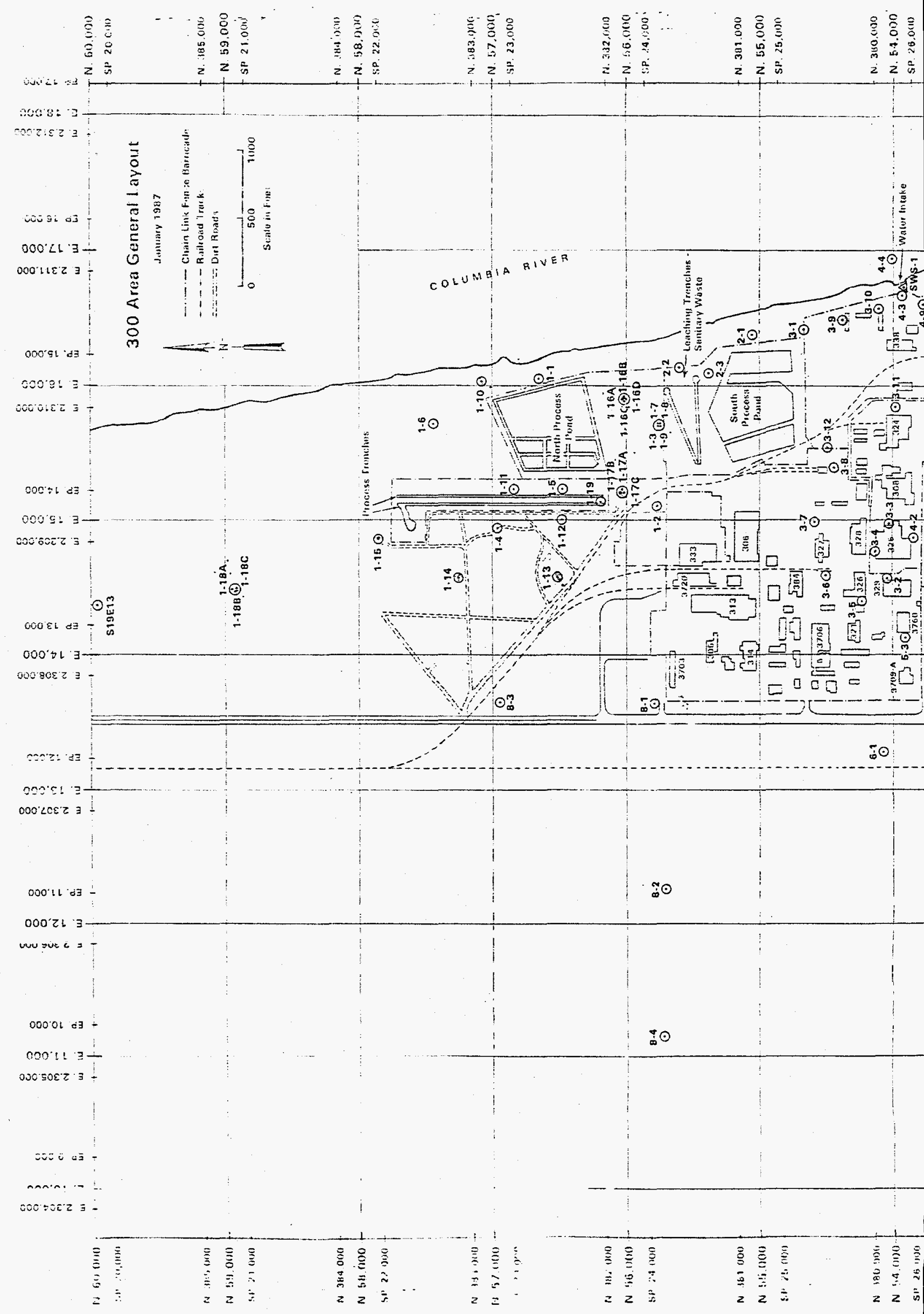




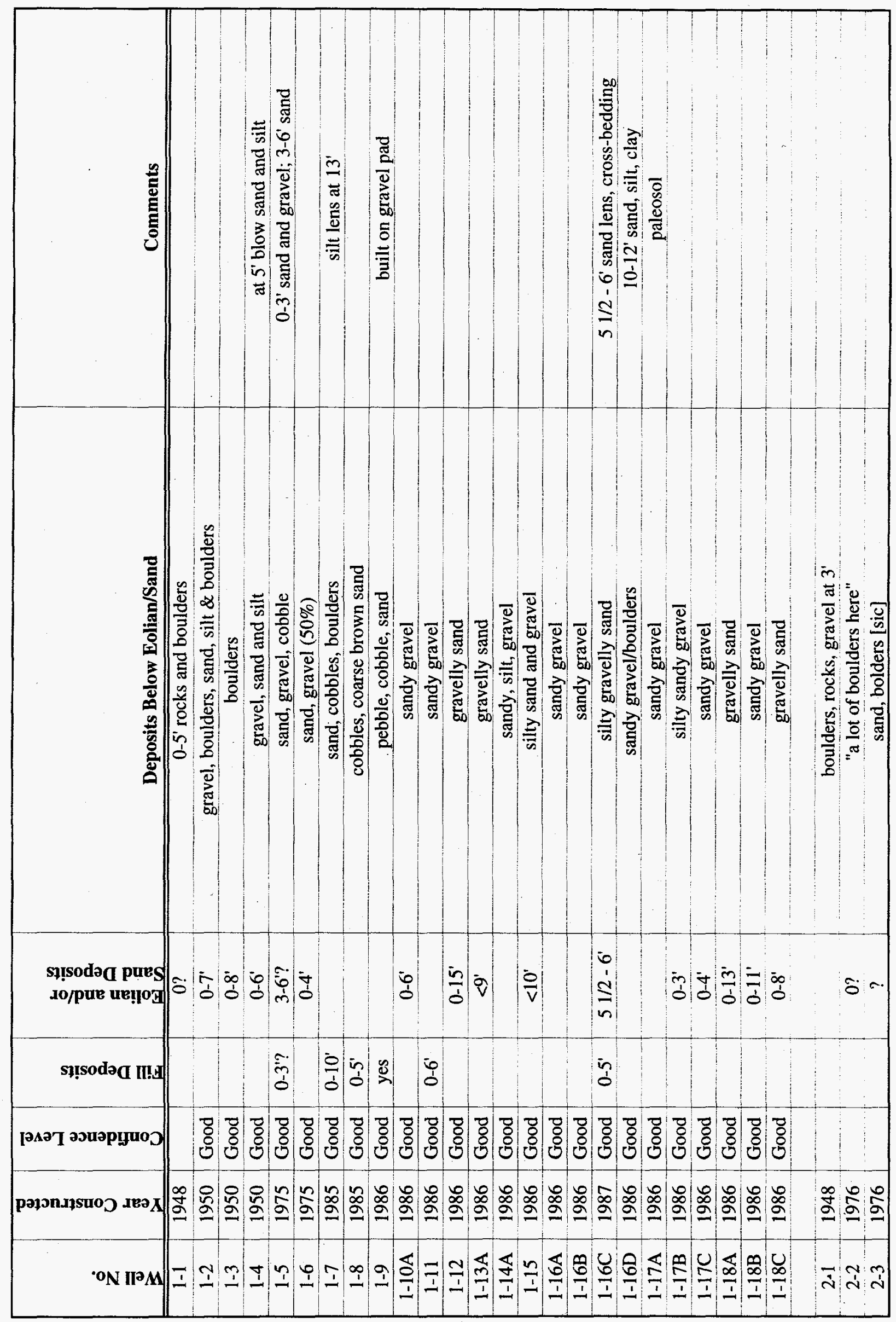

E. 3 


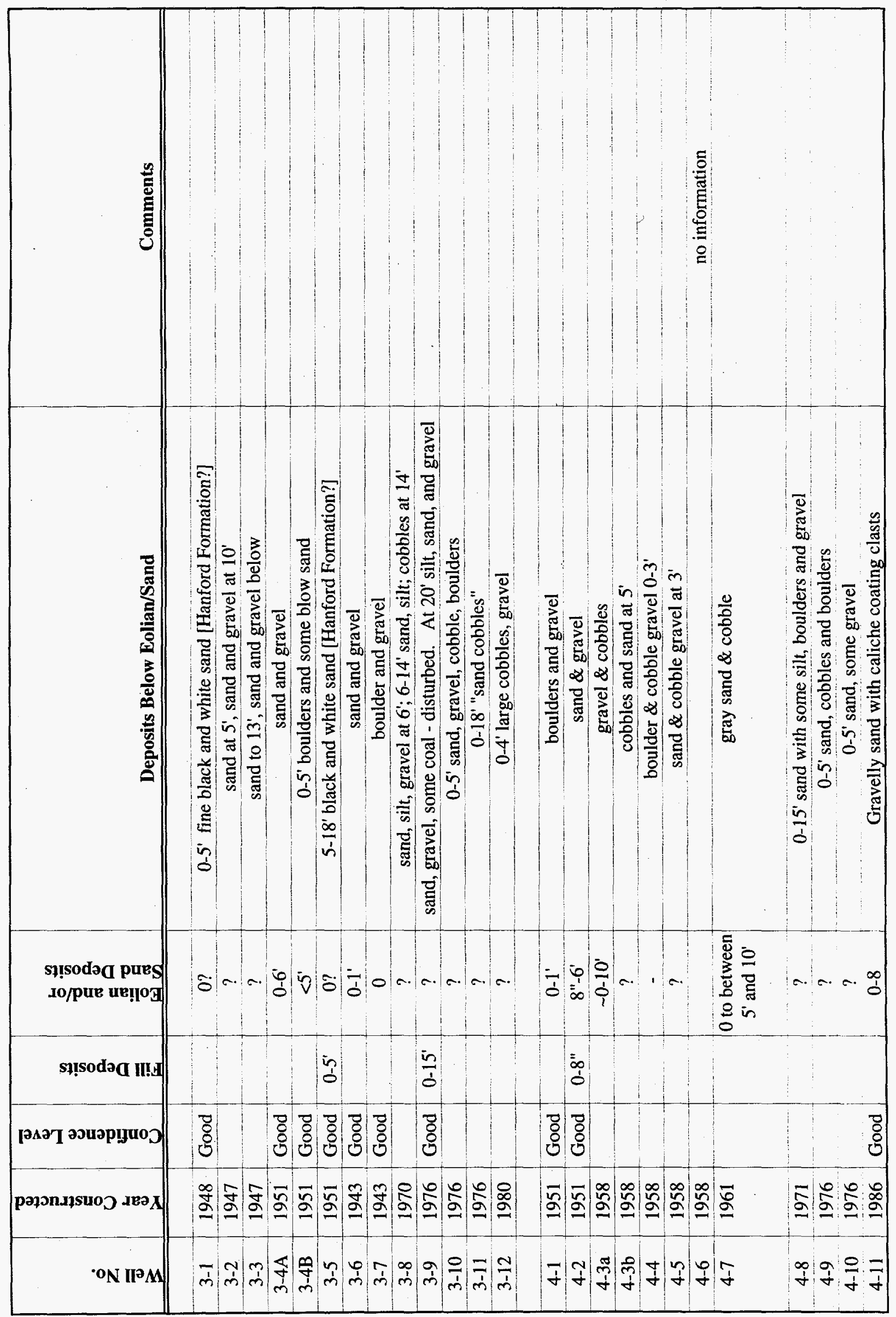




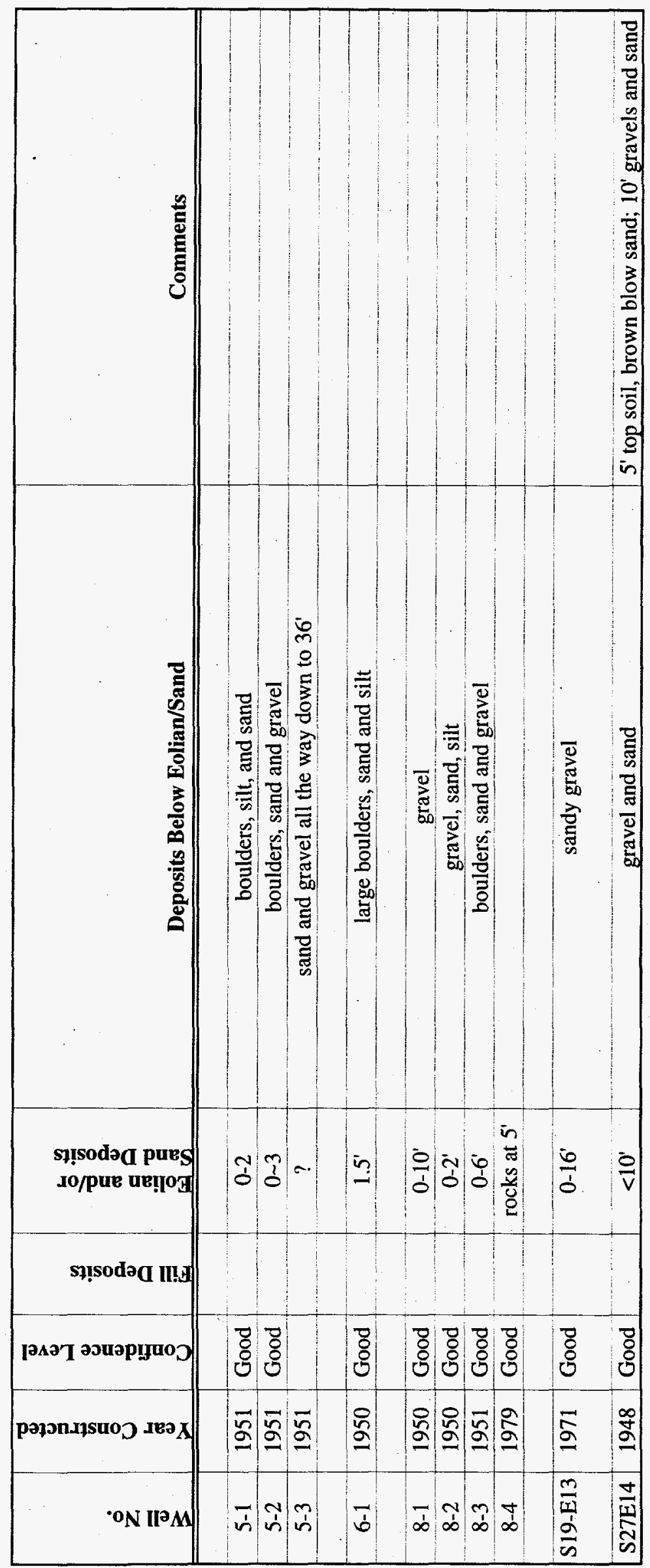

E.5 


\section{Distribution}

No. of

Copies

\section{OFFSITE}

2 A. Fredin Colville Confederated Tribes

P.O. Box 150

Nespelem, WA 99155

2 R. Jim

Yakama Indian Nation

P.O. Box 151

Toppenish, WA 98948

2 J. Lyon

Nez Perce Tribe

P.O. Box 365

Lapwai, ID 83540

2 L. Seelatsee

Grant County P.U.D.

P.O. Box 878

Ephrata, WA 98823

2 J. Van Pelt

The Confederated Tribes of the Umatilla Indian Reservation

P.O. Box 638

Pendleton, OR 97810
No. of

Copies

State Historic Preservation Officer

Office of Archaeology \& Historic

Preservation

420 Golf Club Road SE, Suite 201

Olympia, WA $98504-8343$

\section{ONSITE}

3 DOE, Richland Operations Office

P. F. Dunigan

A5-15

D. W. Lloyd

A5-15

Public Reading Room

A1-65

21 Pacific Northwest National Laboratory

R. Buck

K6-75

N. A. Cadoret

K6-75

L. L. Hale

K6-75

D. C. Stapp

K6-75

M. K. Wright (10)

K6-75

Information Release Office (7)

K1-06

Distr.1 